\title{
استفادة الشباب الجامعي من وقت الفراغ (دراسة وصفية تحليلية في جامعة والئة
}

(المنصورة)

داع/ إيمان تحمد الصياد

مدرس علم الاجتماع بكلية الآداب - جامعة كفر الثيخ

مدرس علم الاجتماع الريفي بكلية الزراعة جامعة كفر الثيخ 


\section{المقدمة والمشكلة البحثية}

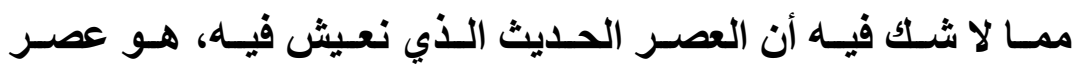

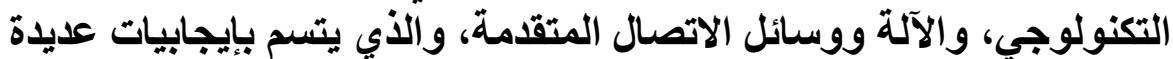

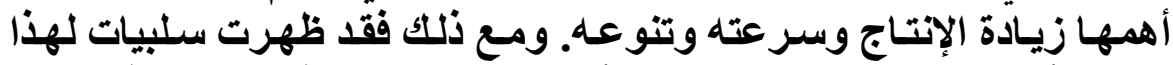

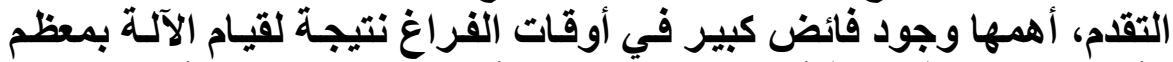

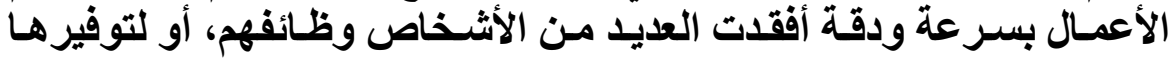

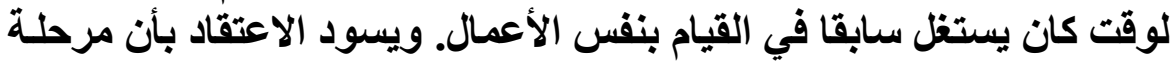

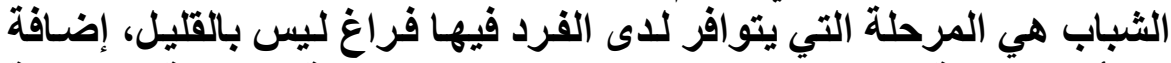

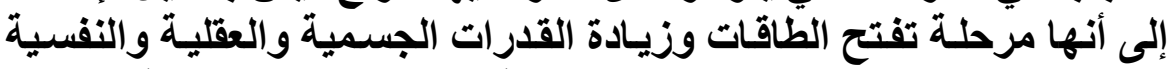

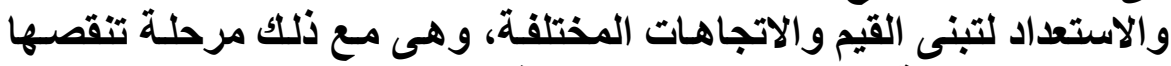
الخبرة والتجربـة وتحركها الغرائز وتــفعها الثـهـوات (الصـفير، 2001:

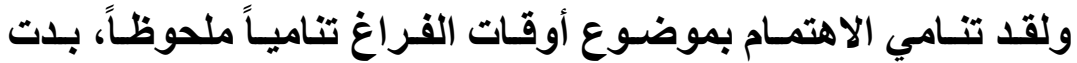

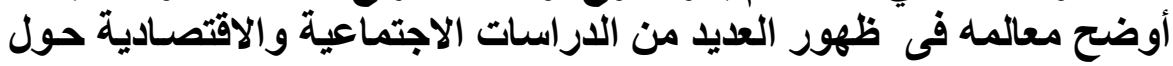

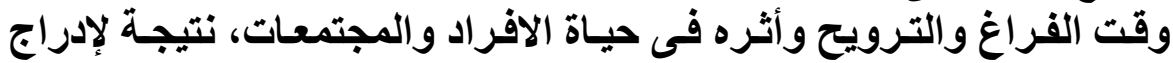

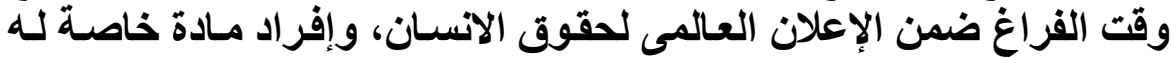

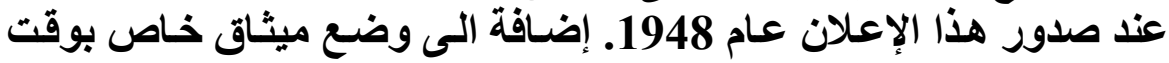

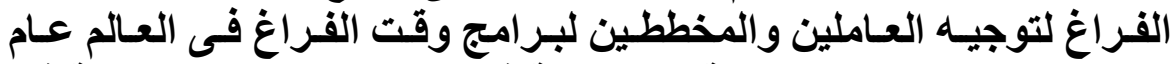

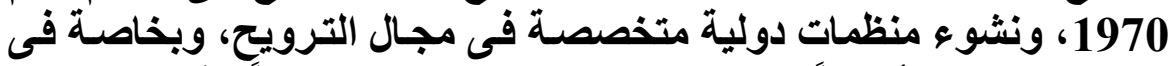

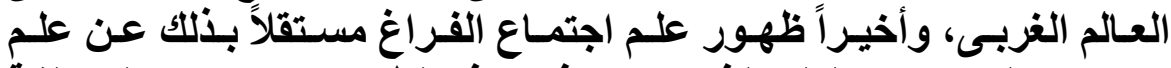

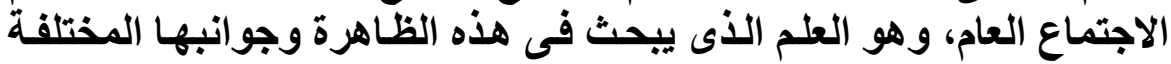

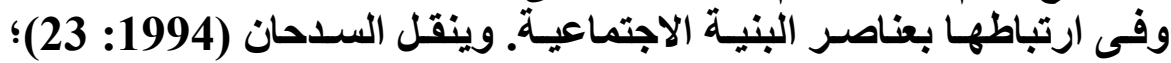

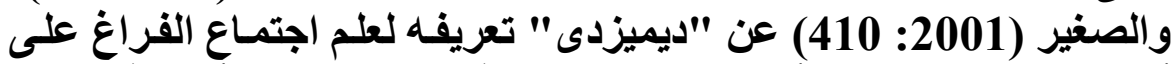

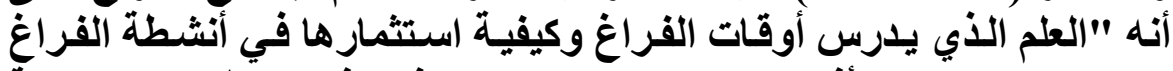

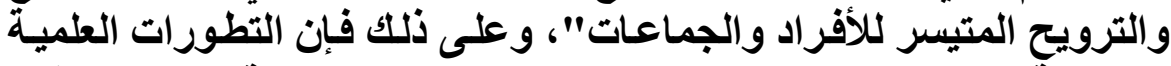

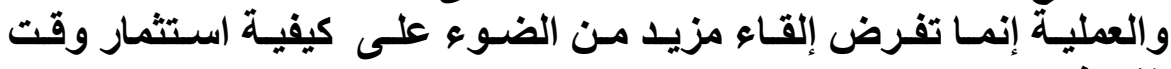
الفراغ.

ويعد فهر طبيعة مرحلة الثباب ومـا تنطوي عليه من سمات نفسية

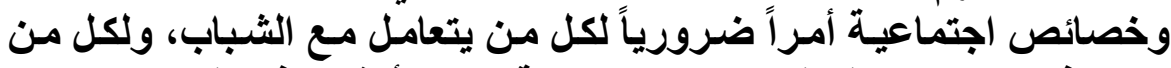

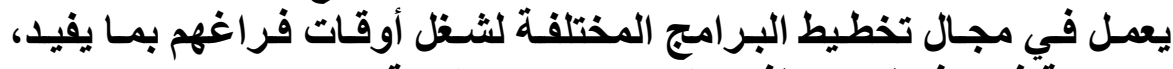

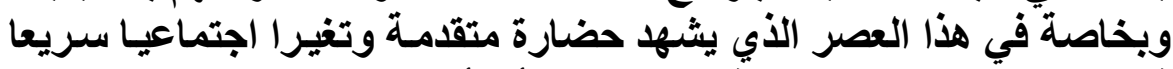
في شنى مجالات الحياة، والأي كان من شأنه أن يزيد معدل الفراغ مع نقص القصائ 


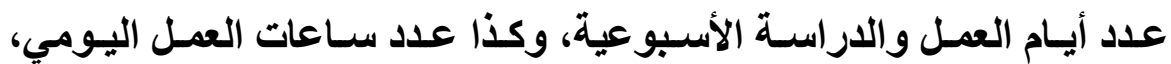

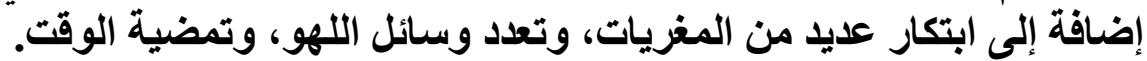

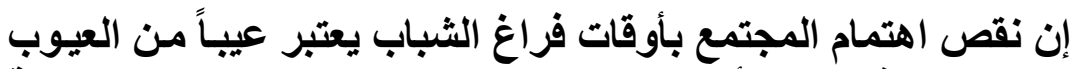

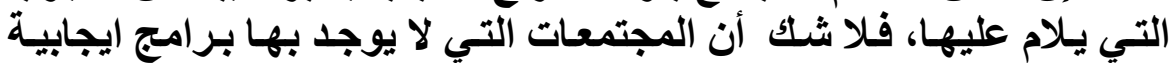

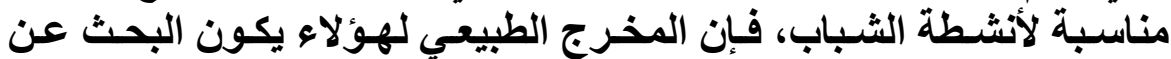

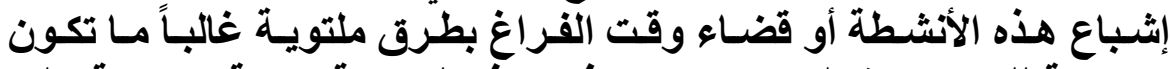

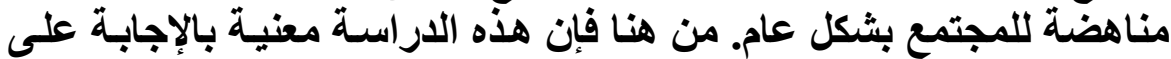

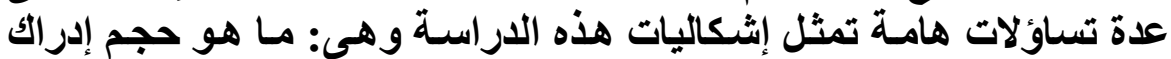

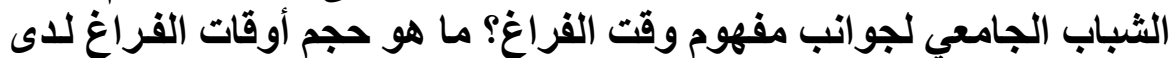

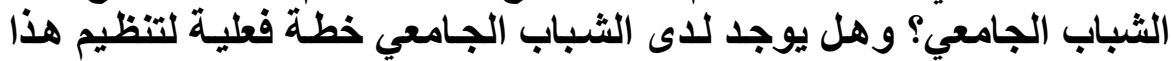

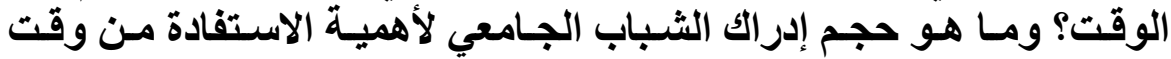

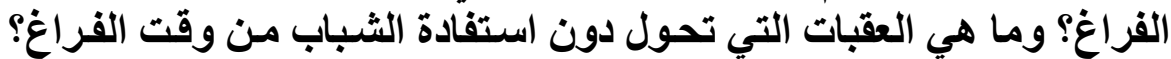

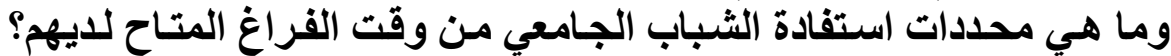

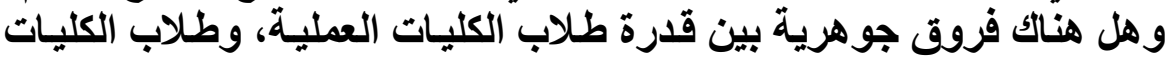

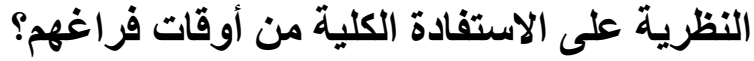

$$
\text { أهداف الدر اسةة: }
$$

استهدفت هذه الدراسة بصفة أساسية دراسة استفادة الثباب الجامعي

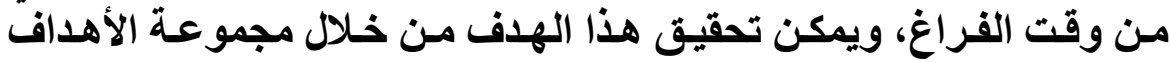
الفرعية التالية:

1- التعرف على مـدى إدراك الشـباب الجـامعي لجوانب مفهوم وقت القراغ.

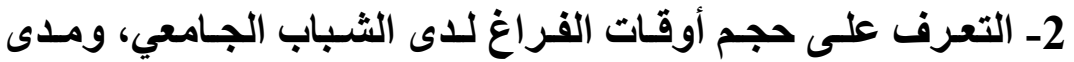
وجود خطة فعلية لتنظيم أوقات الفراغ.

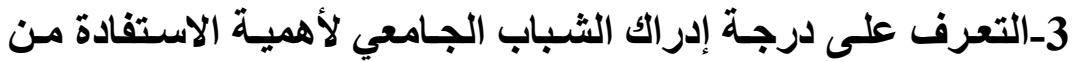
وقت الفراغ، وما هي أهم العقبات التي تحول دون الأبتاب التفادة من هذا الوقت. 4- الوقوف على محددات استفادة الشباب الجامعي من وقت الفراغ. 5- التعرف على مدى وجود فروق جوهرية بين طلاب الكليات العملية والكليات النظرية في الاستفادة الكلية من وقت فوف الفراغ من عدمده. أهمبة الدرابة اسة: 


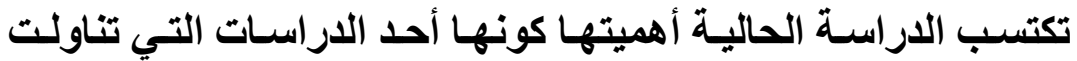

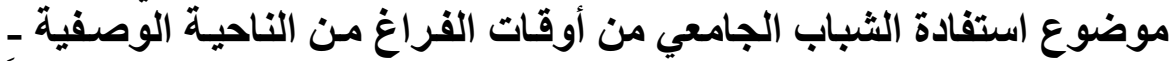

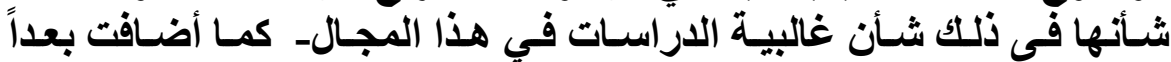

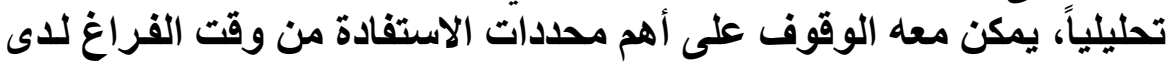
الشباب الجامعي بصورة كمية.

\section{الإطار النظري والاستعراض المرجعي:}

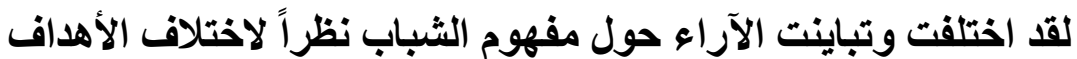

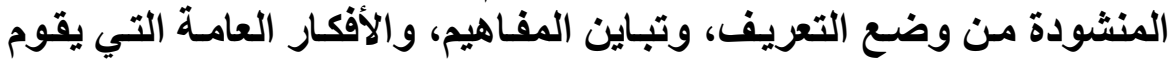

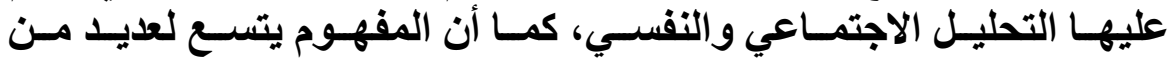

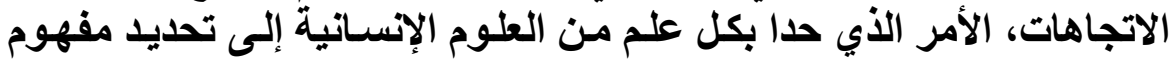
الثباب من منظوره الخاص. الاصن.

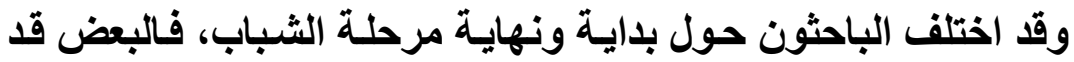

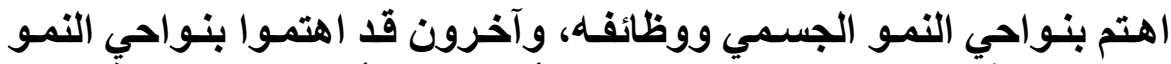

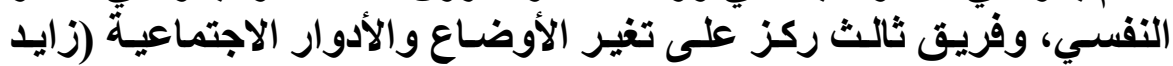

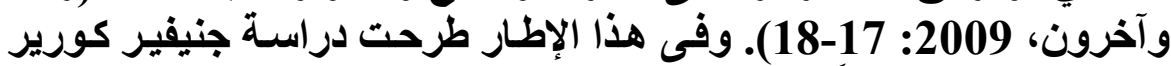

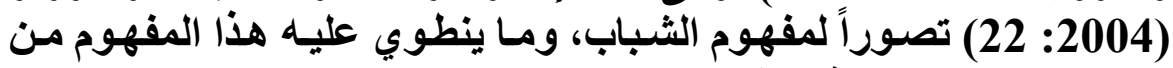
دلالات يمكن حصرها في الآتي :

1-المفهوم الأكثر عمومية والأي ينظر إلى مرحلة الثباب باعتبارها

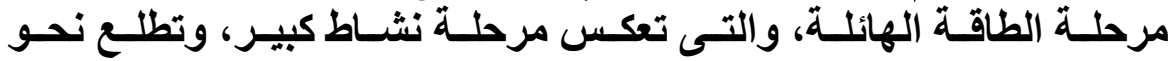

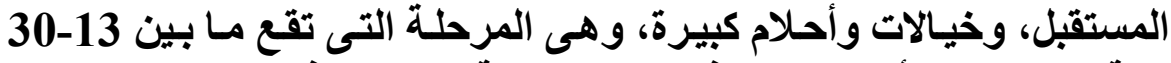

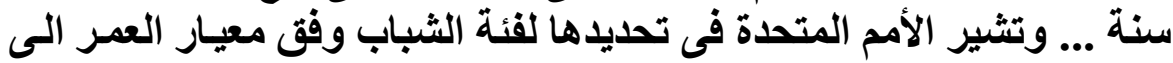

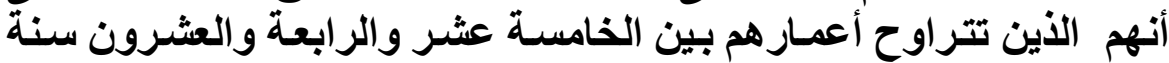

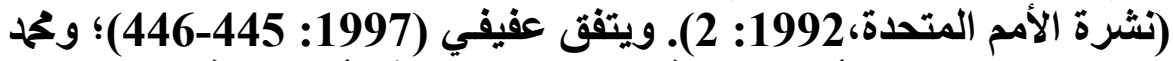

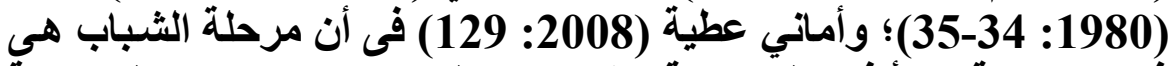

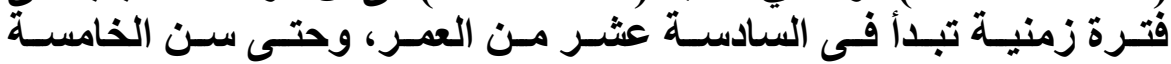

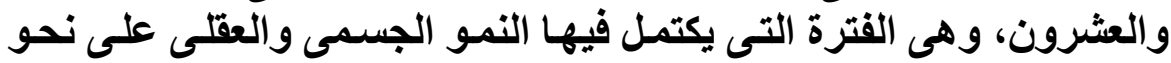

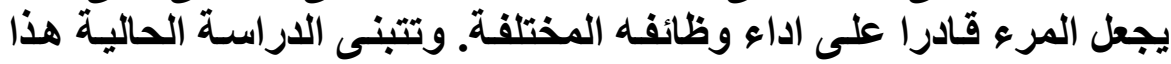

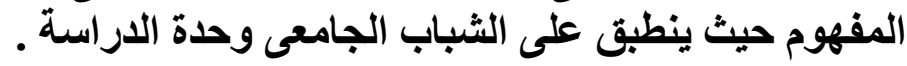

2-التصور الثانى لمفهوم الثباب، والذي ينظر إلى الثباب من زاويـة

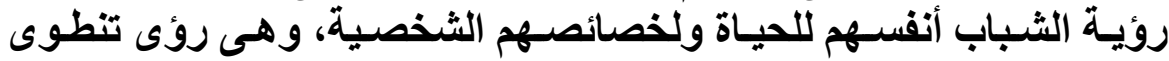

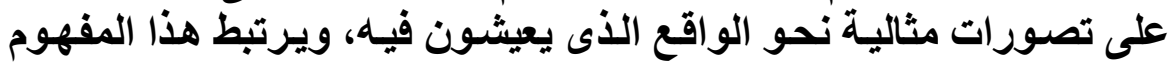
بخصائص معينة تدور حول السعى نحو احراز المكانة المجتمعية في الحياة. 


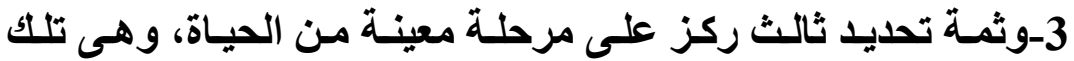

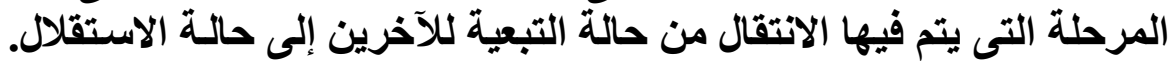

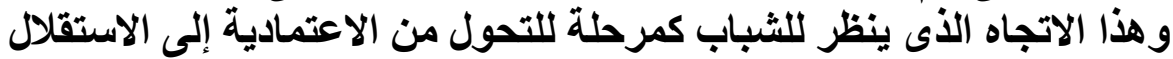

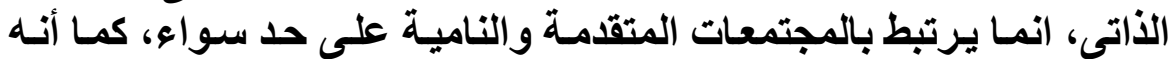

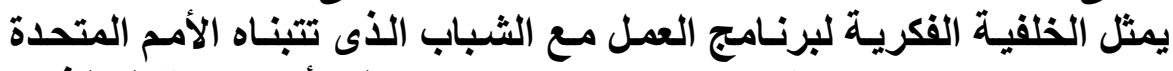

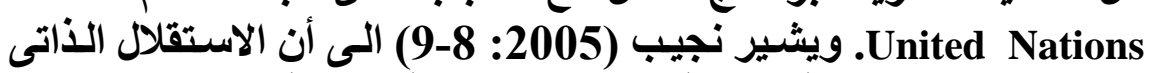

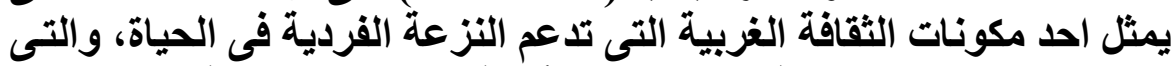
تتجاوز الارتباطات العائلية والجماعات الأولية، وعلاقات الثراتية الترابة وغير ذلك.

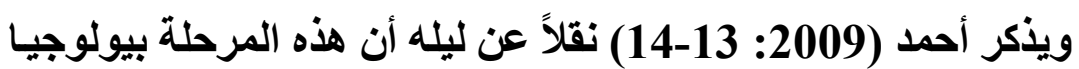

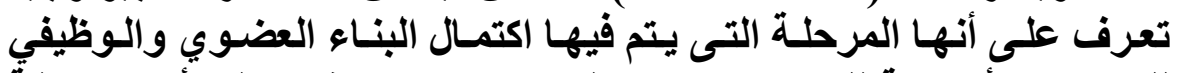

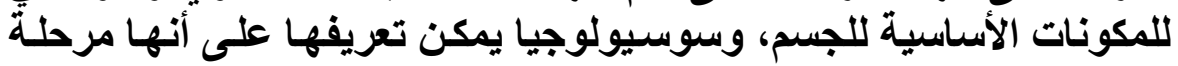

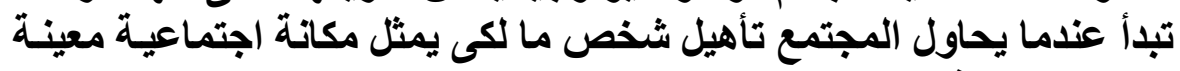

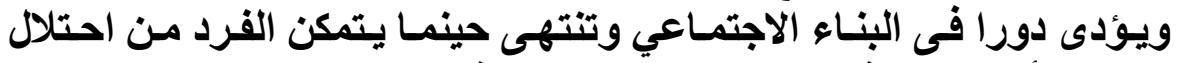

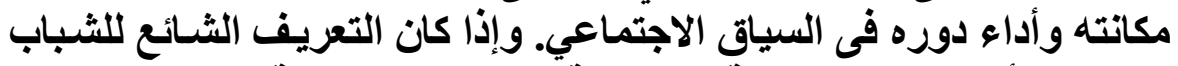

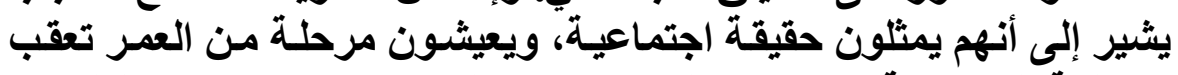

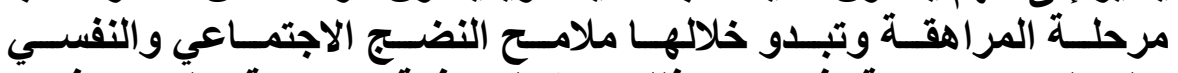

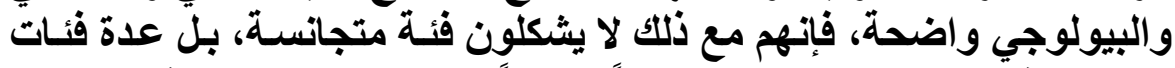

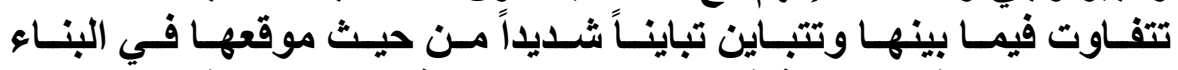

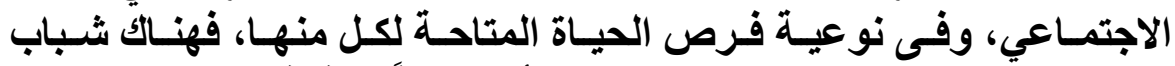

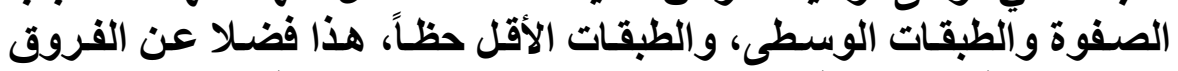

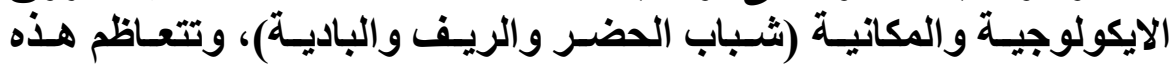

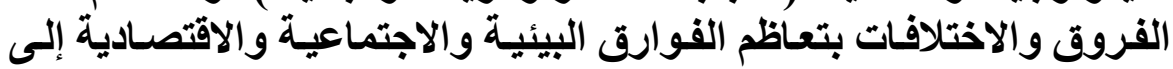

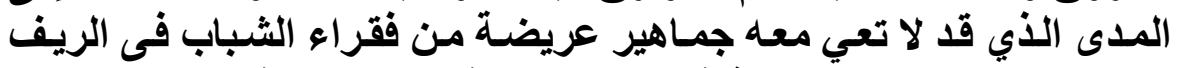

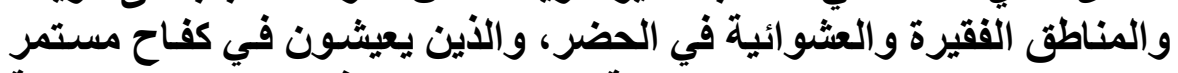

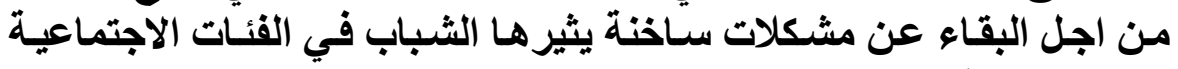
العليا والوسطى (نجيب، 2005: 10 10)

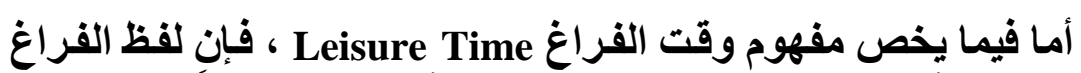

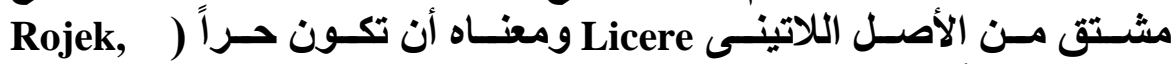

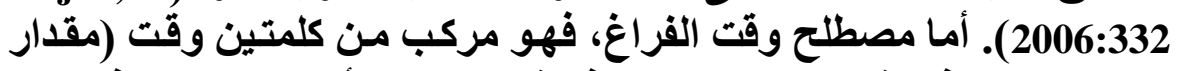

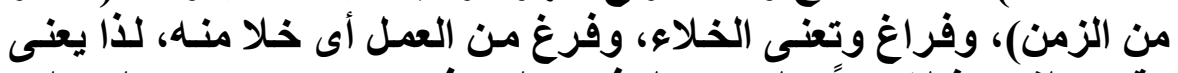

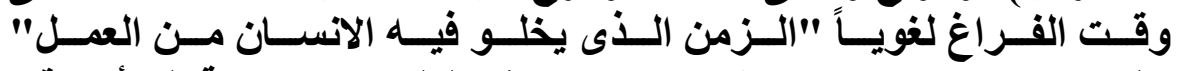

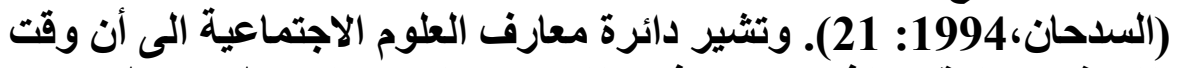

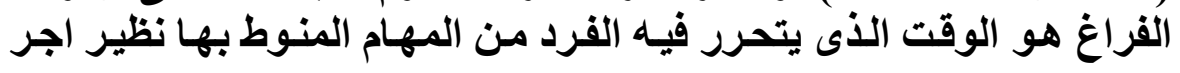


معين بصورة مباشرة او غير مباشرة. وهذا يعنى أن وقت الفراغ هو الوقت

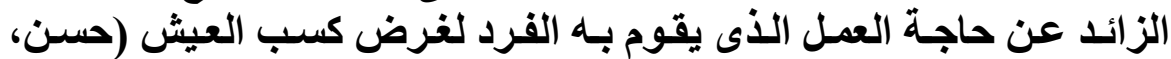

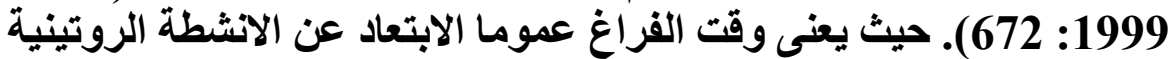

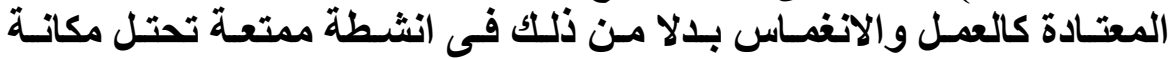

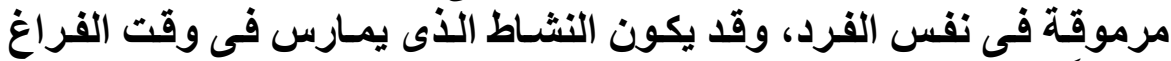

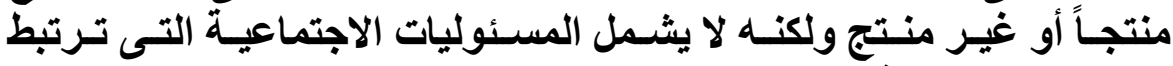
بالادوار الاجتماعية الاخرى للفرد (مارشال، 2000: 715-715).

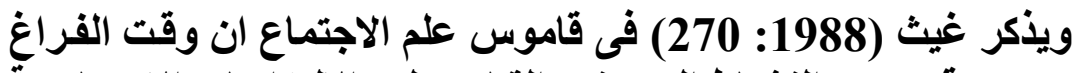

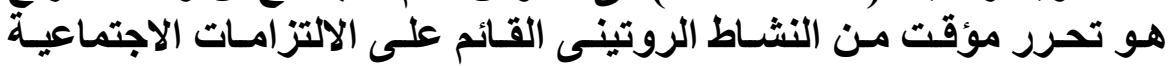

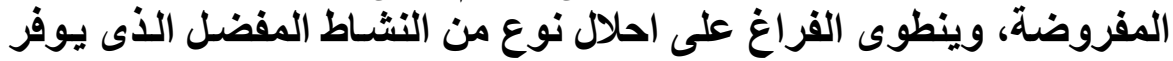

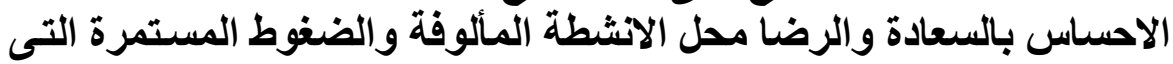

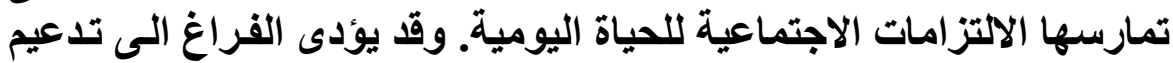

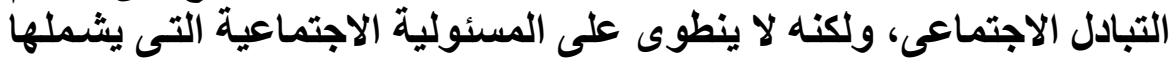

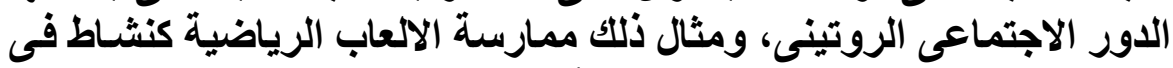

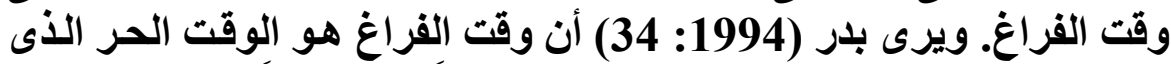

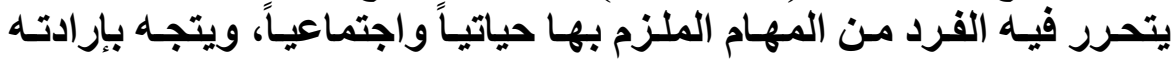

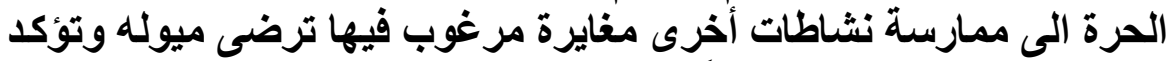
ذاته، وتضفى على حياته نوعاً من التنوع وتقضى التفى على طابع الرتابـة و الملل وتجلب لله في النهاية السرور والسعادة.

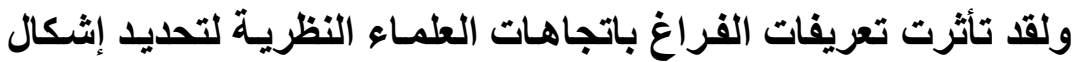

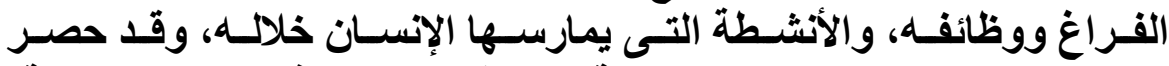

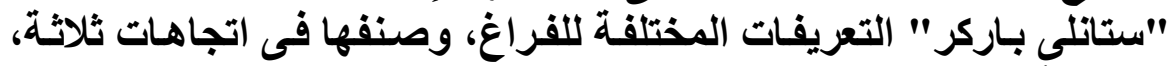

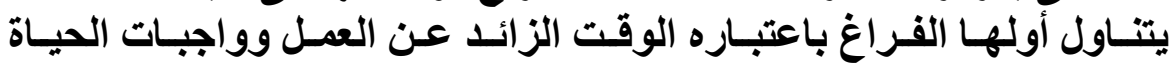

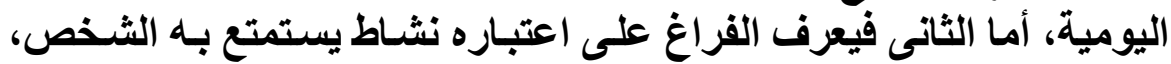

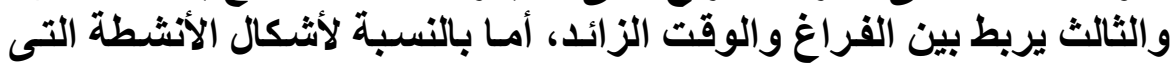

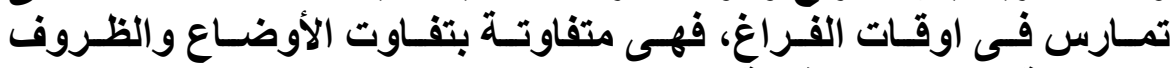

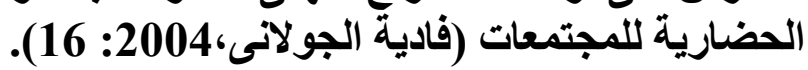

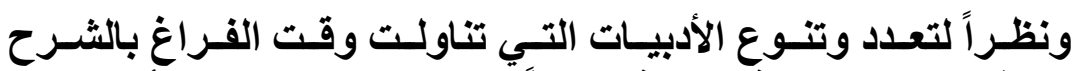

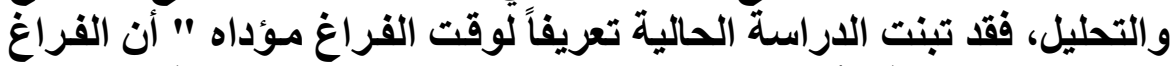

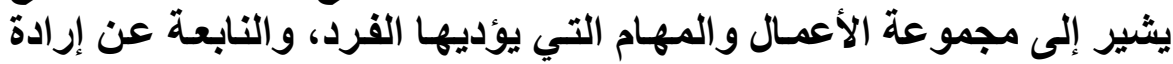

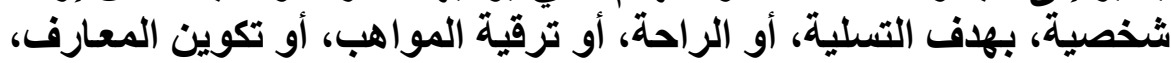

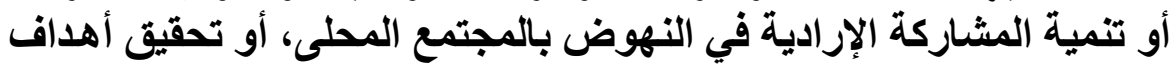

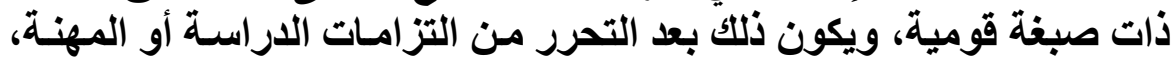




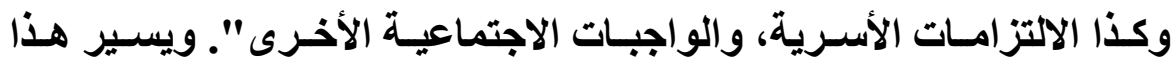

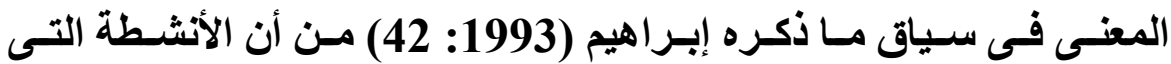

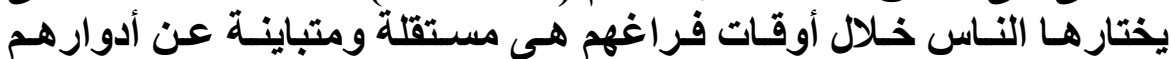

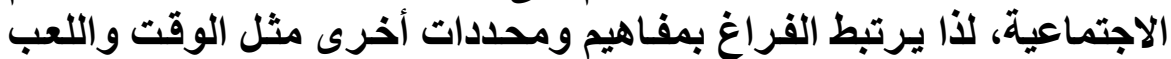

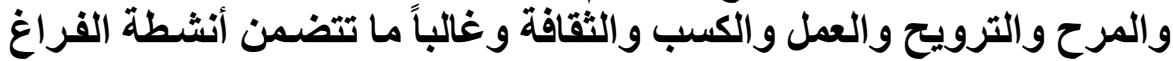
أسمى المعاني والغايات لاى الإنسان ألا وهى تحقيق ذاته في الفى الفعل أو العمل.

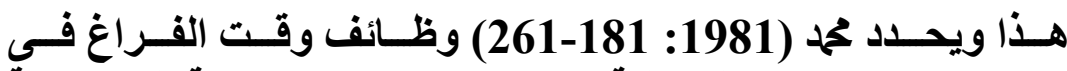

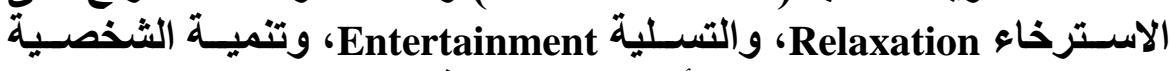

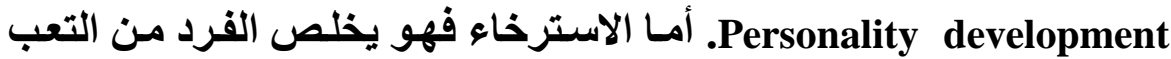

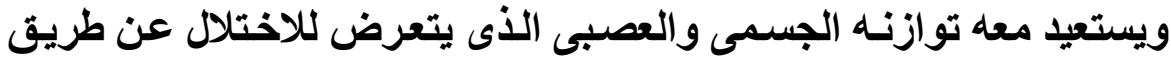

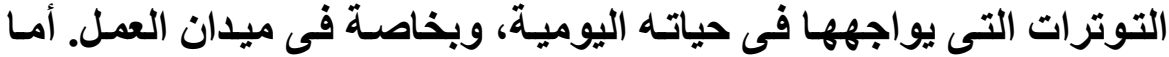

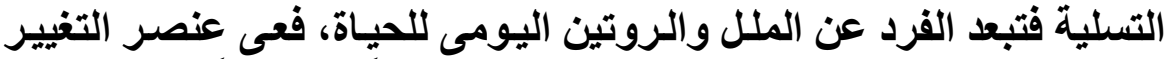

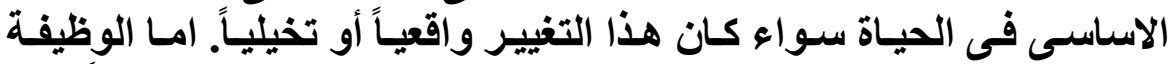

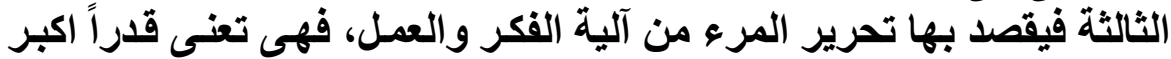

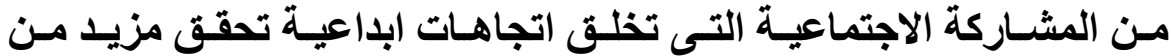

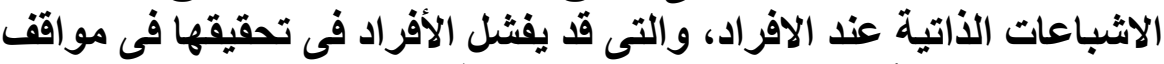
كثيرة فى مجتمع أصبح الإحباط ظاهرة واضد واضحة فئه فيه.

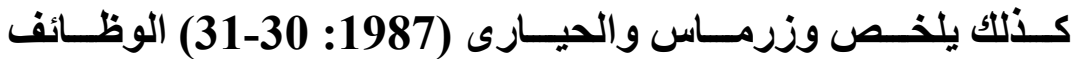

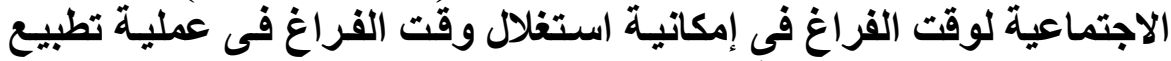

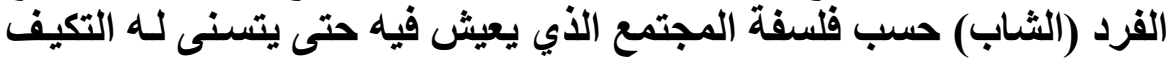

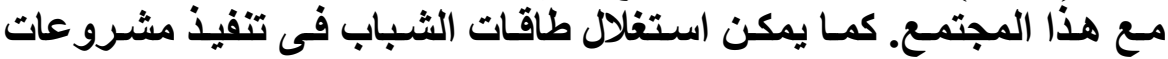

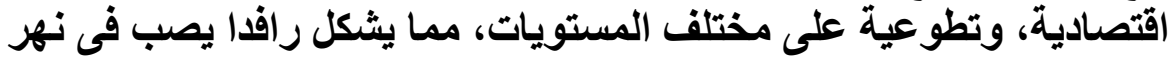
الاحساس بالانجاز ، ومن ثم الانتماء علمع للمجتمع.

من الطبيعي والمنطقي أن يمل الفرد من الاستمرار في عمل مـا بشكل

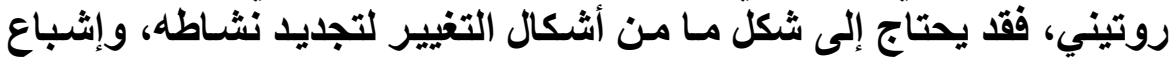

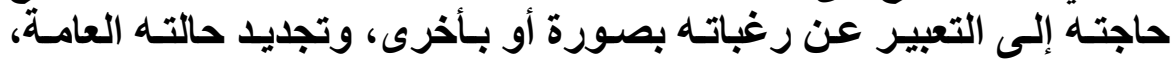

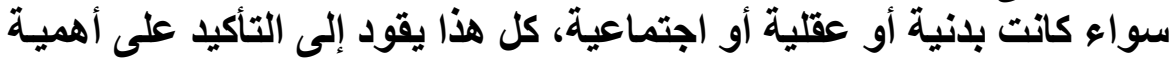

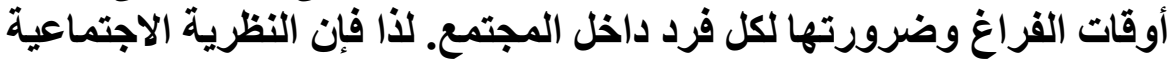

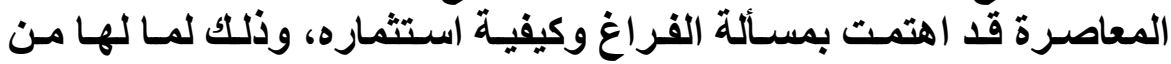

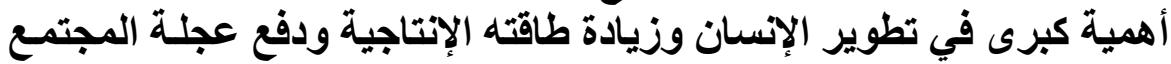

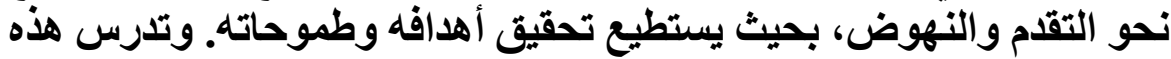

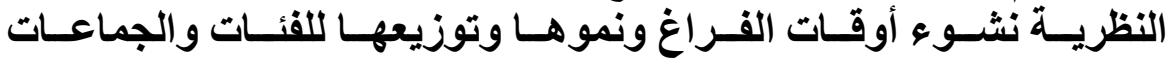

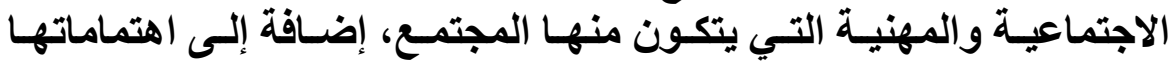


بمسيائل تنظيم وقت الفراغ وأهدافهـ ووسـائله والظروف التي تسـاعد أفراد

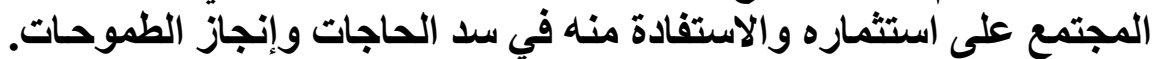
.(Etzkowitz and Glassman, 1997: 367)

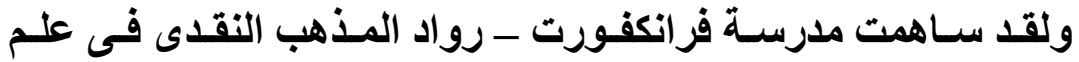

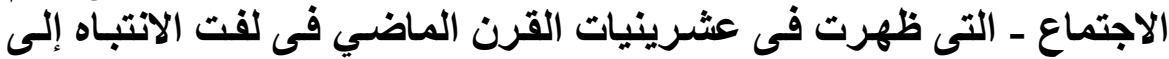

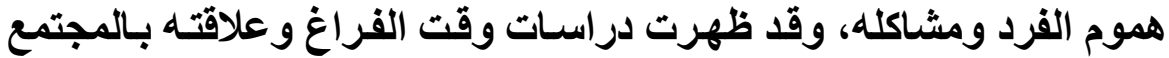

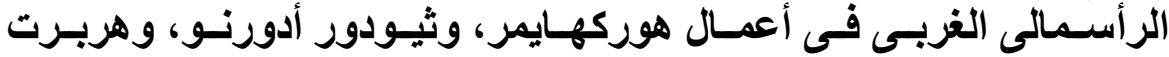

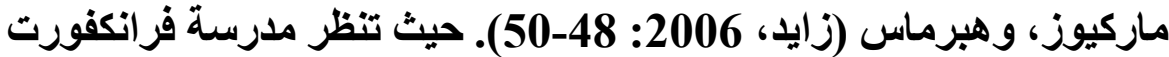

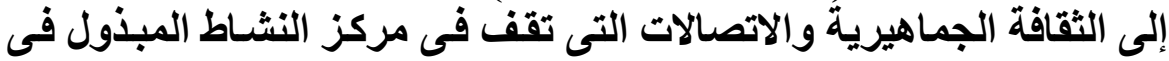

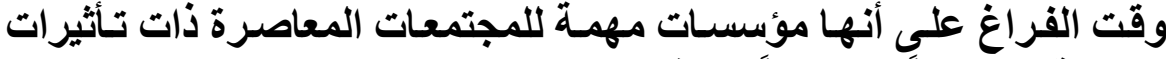

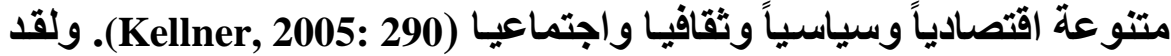

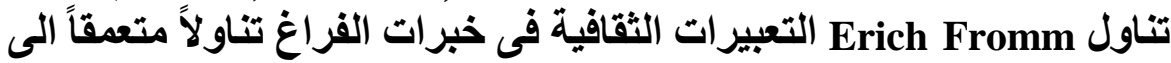

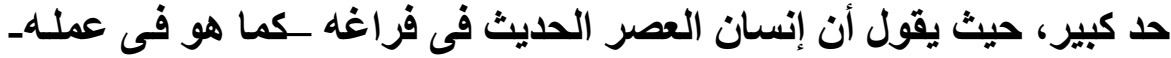

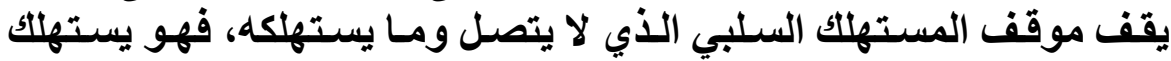

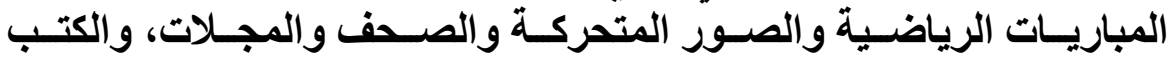

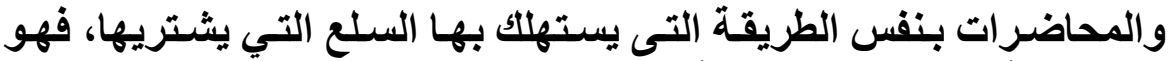

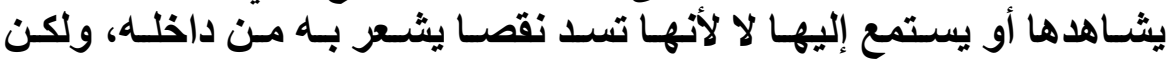

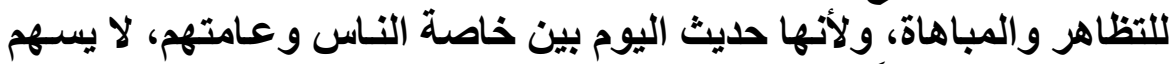

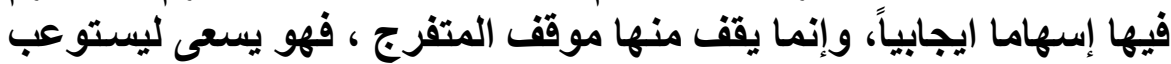

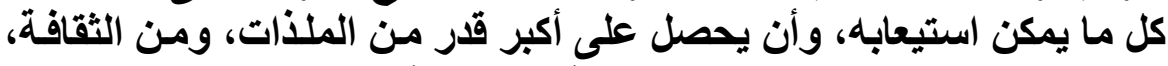

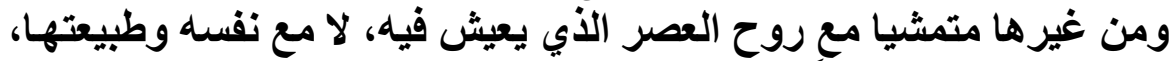

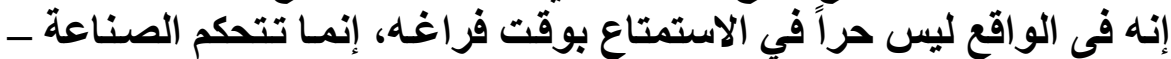

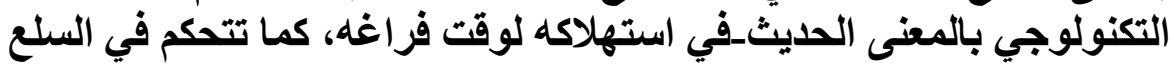

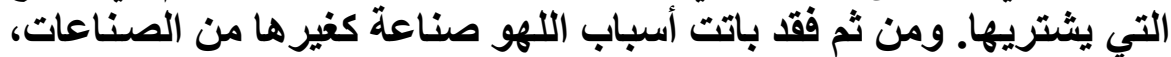

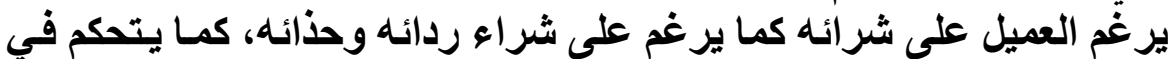

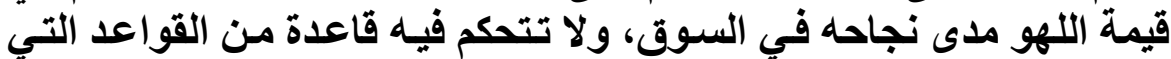
يمكن قياسها بالمعايير الإنسانية (فروم، 1960: 102-101).

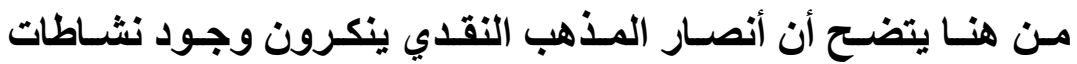

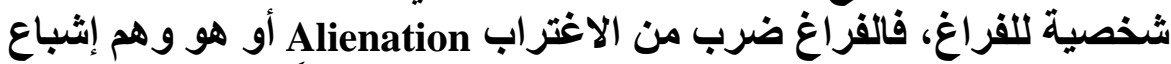

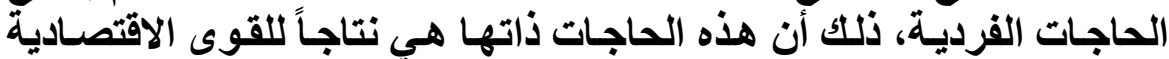

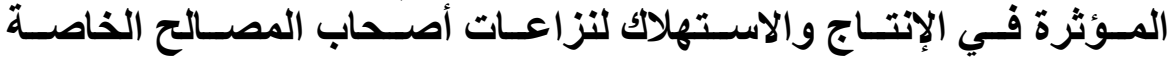

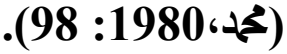




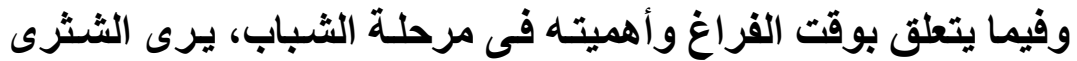

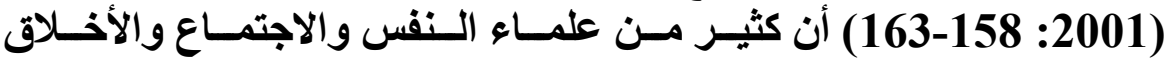

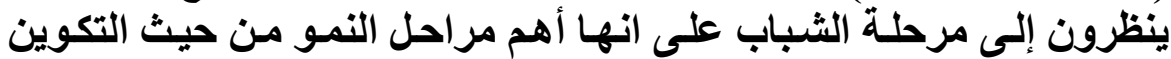

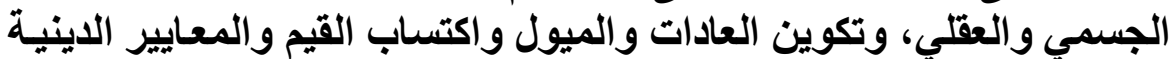

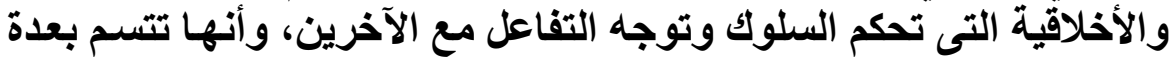

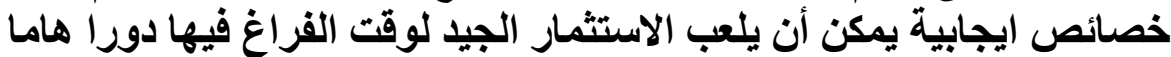

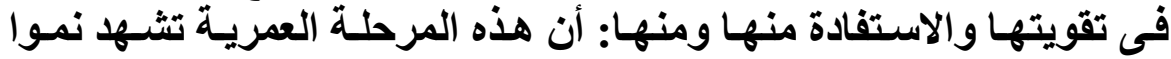

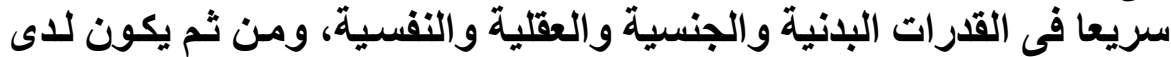

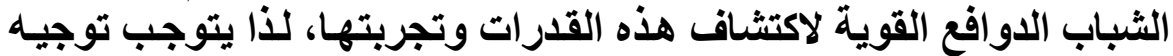

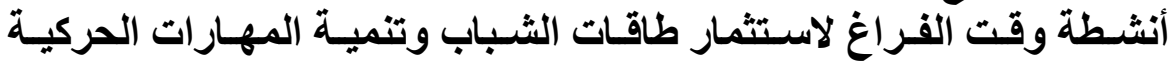

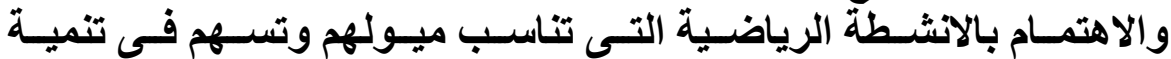

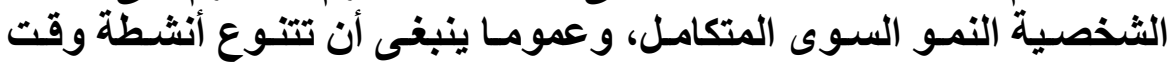

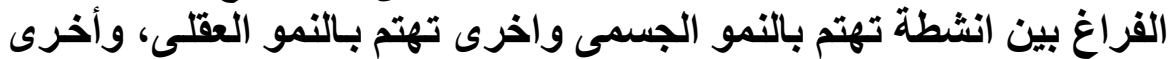

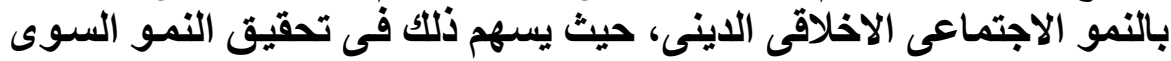

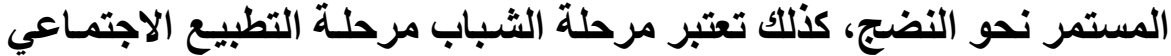

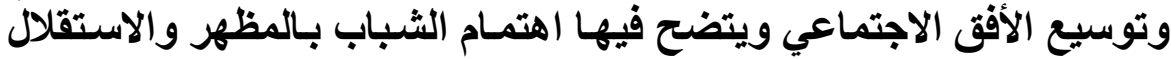

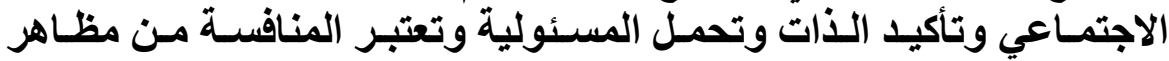

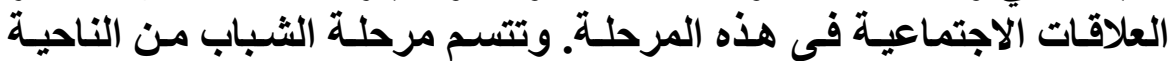

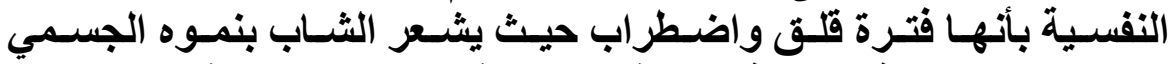

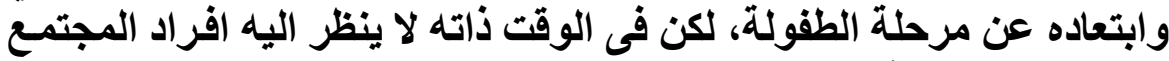

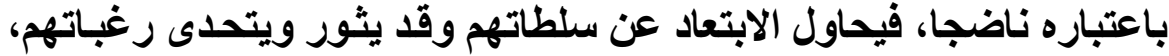

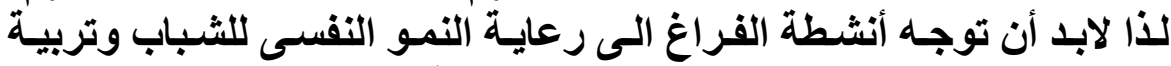

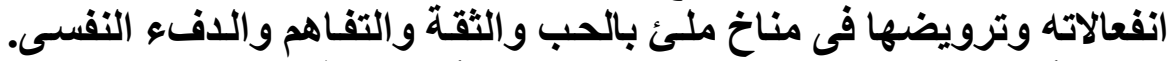

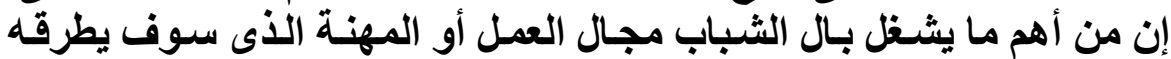

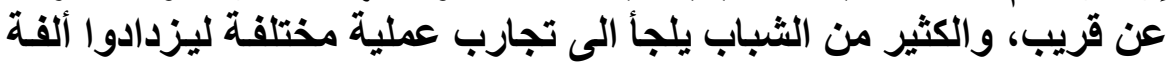

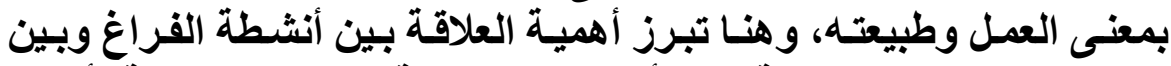

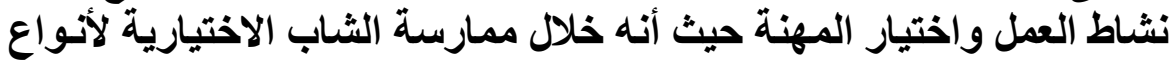

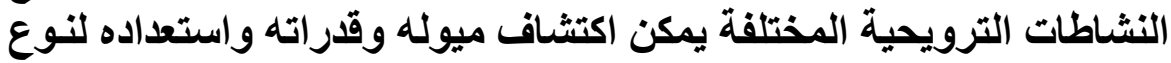

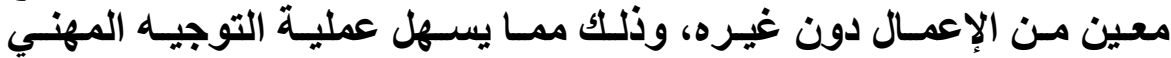

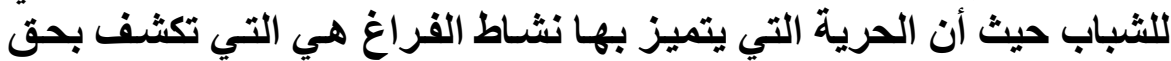

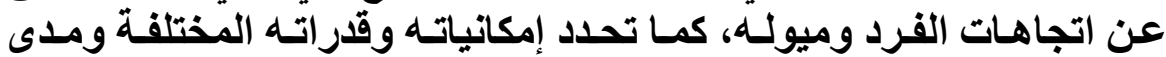
تحمله لأعباء مهنة معينة دون غيرهات الجها 


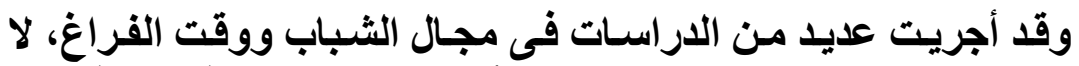

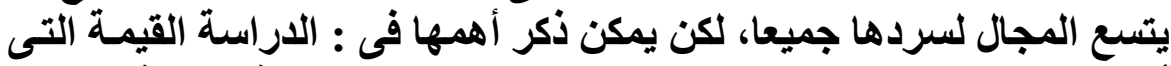

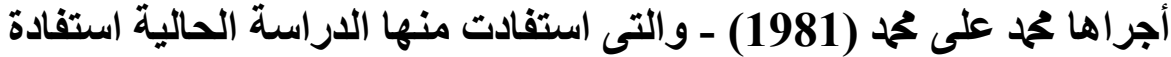

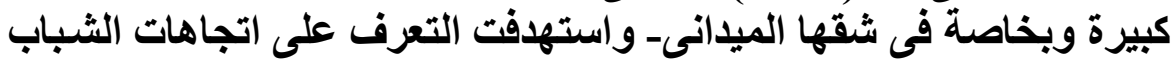

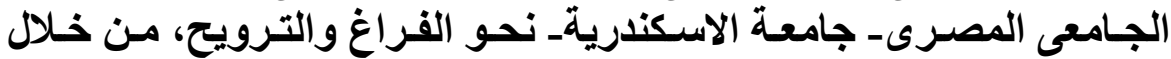

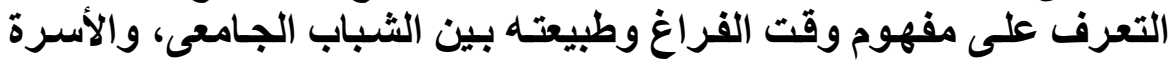

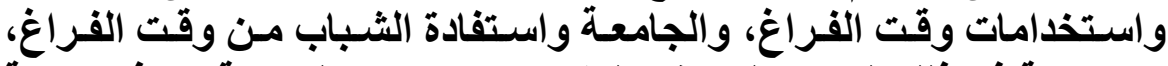

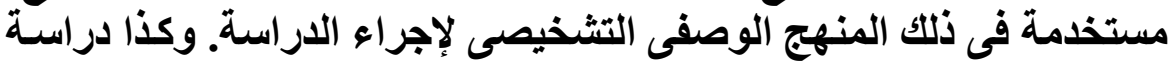

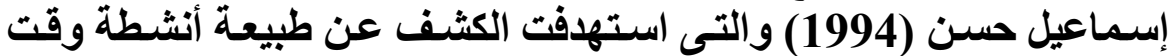

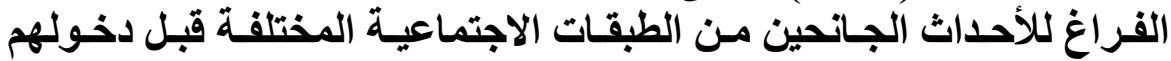

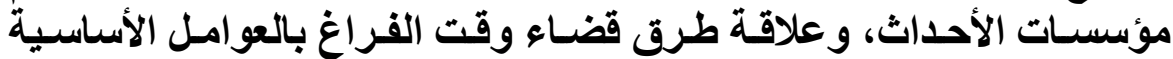

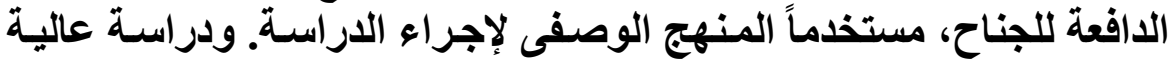

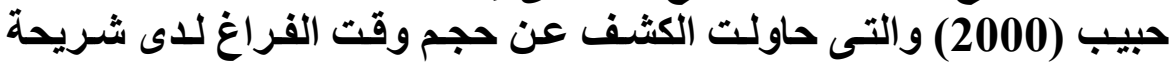

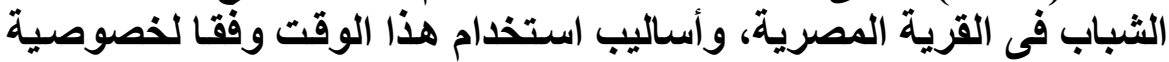

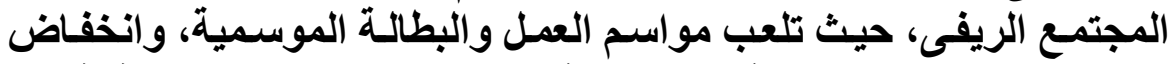

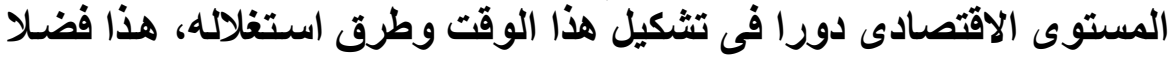

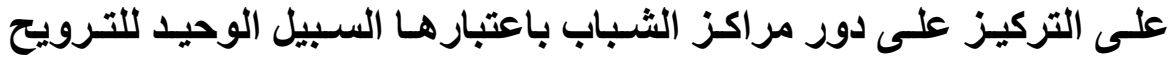

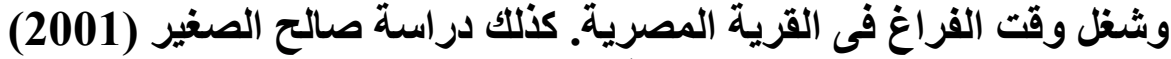

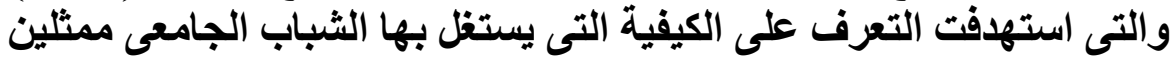

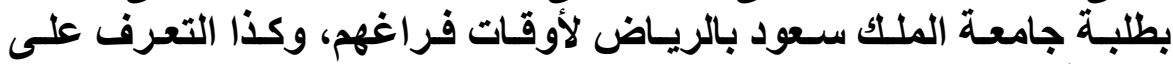

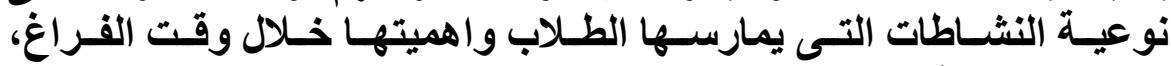

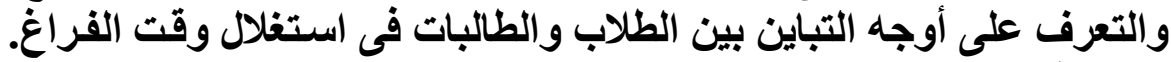

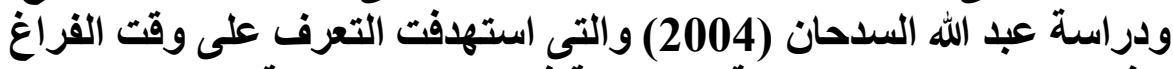

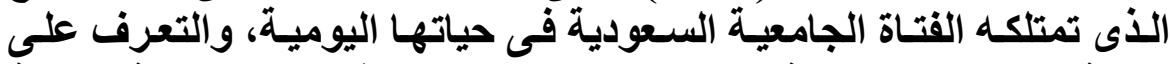

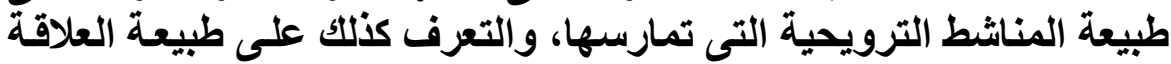

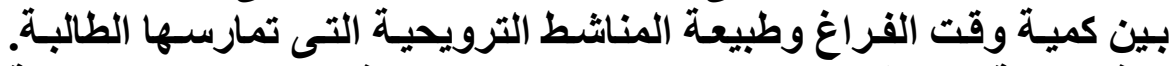

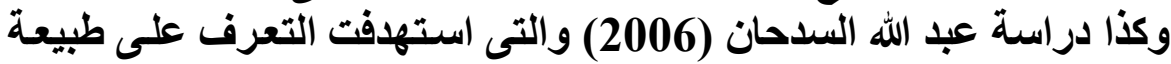

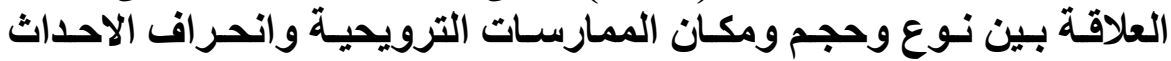

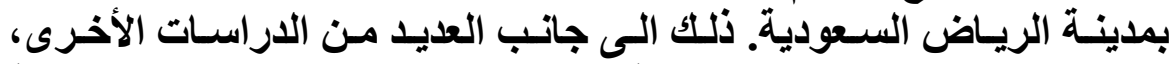

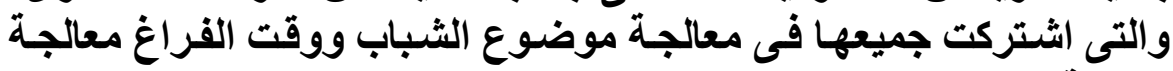

$$
\text { أولاً : مجالات الإراسة البهة:ة }
$$


تثــتمل مجـالات الاراســة عـــي المجـالات الجغرافيـة، والبثـرية،

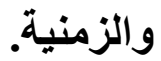
أ) المجال الجغرافي:

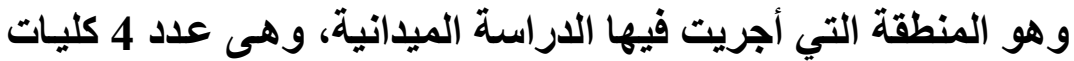

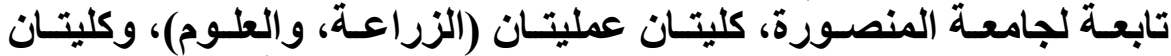
نظريتان هما كليتي (الآداب و التجارة)، تم اختيار ها عشوانيأ الئاً بطريقة السلة.

ب) المجال البشري:

ويقصد بالمجـال البثري الأفراد الذين سيطبق عليهم أدوات البحث

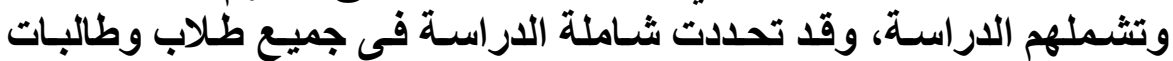

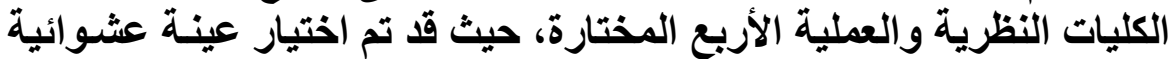

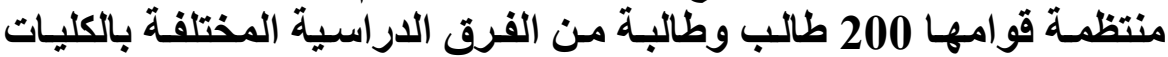
الأربع، بواقع 50 طالب وطالبة تم اختيارهم من سجلات القيد بكل كلية.

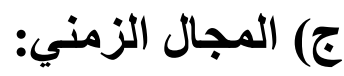

يقصد بالمجال الزمني الفترة الزمنية التي تم جميع البيانـات فيها من التهن

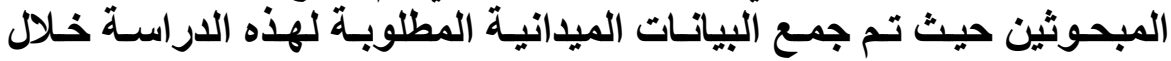

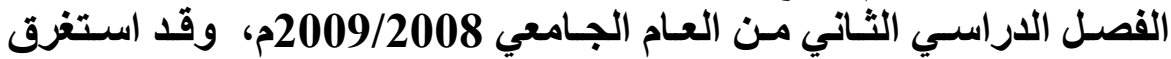
استيفاء كل استمارة نحو ساعتين فى المتوسط.

ثنانياً: قياس متغيرات الدراسة

استخدمت الدراسـة 21 متغيـرا بحثيـاً منهـا 17 متغيـرا مستقلاو و 4 متغيرات تابعة تم قياسها كالآتي : أ_قياس المتغيرات المستقلة:

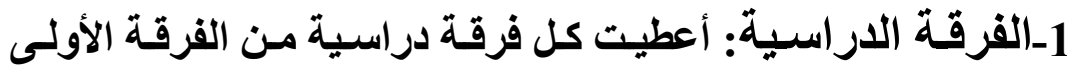
للرابعة درجات 1، 2، 3، 4 على الترتيب.

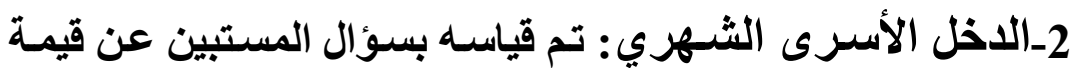

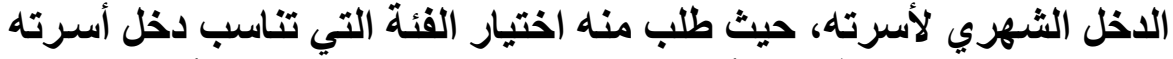

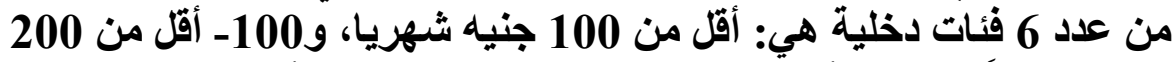
جنيه شهرياً، و300- أقل من 500 جنيه شهريا، و500- أقل من 700 جنيه 


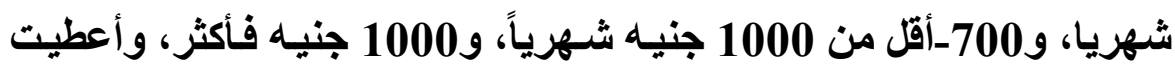

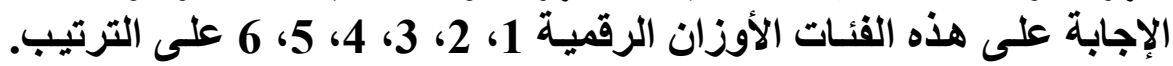
بمتوسط 5.2 درجة وانحراف معياري قردان الرهية 1.1 درجة.

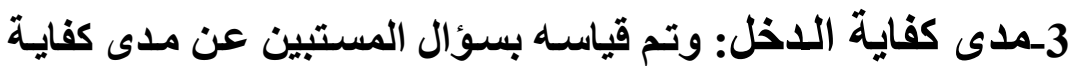

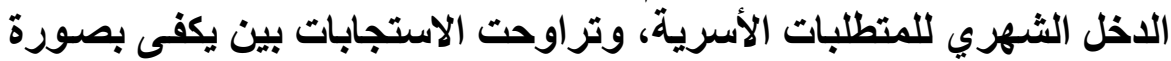

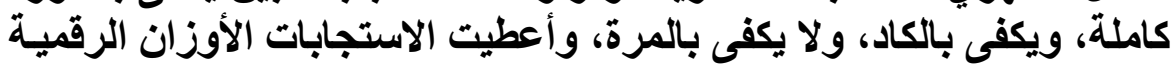

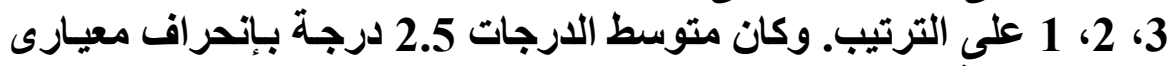

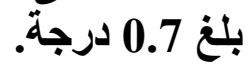

4ـعدد غرف المسكن: رقم خام يعبر عن عدد غرف المسكن الذى الذى

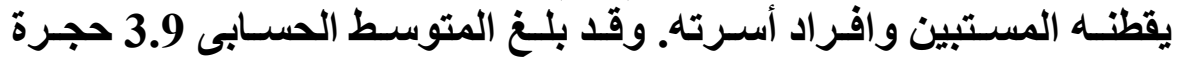
بإنحر اف معيارى بلغ وافئ 1.03 حجرة.

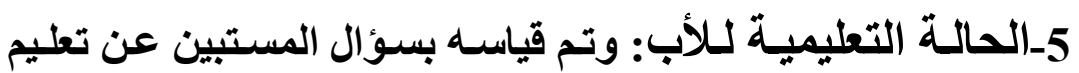

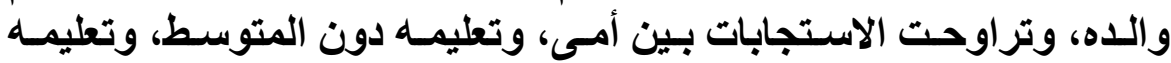

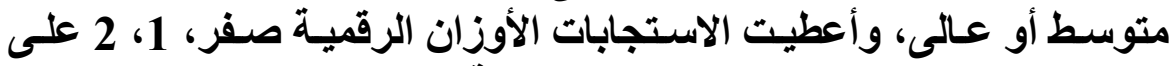

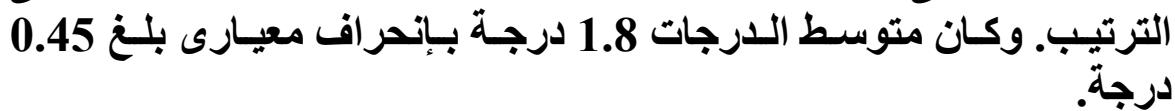

6_الحالة العملية للأب: وتم قياسه بسؤال المستبين عن عمل والدهاه،

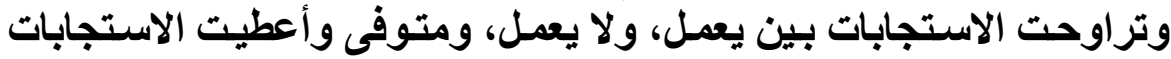
الأوزان 2.8 درجة بإنحراف معيارى بلغ 0.44 درجة.

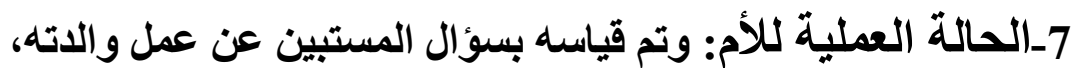

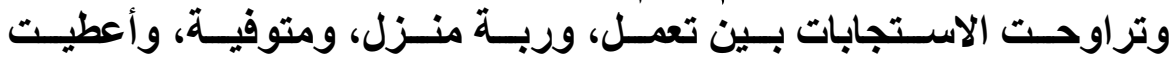

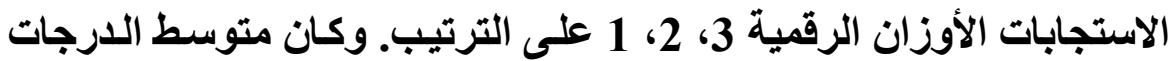
2.3 درجة بإنحراف معيارى بلغ الأغ 0.7 درجة.

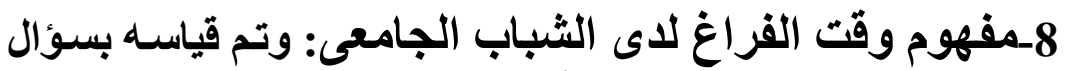

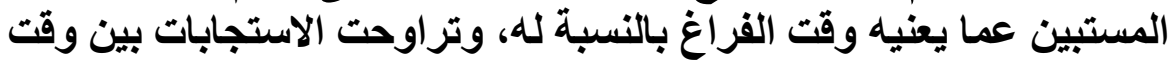

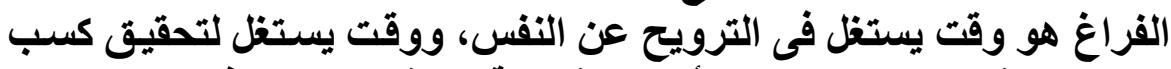

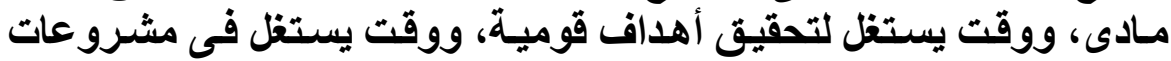

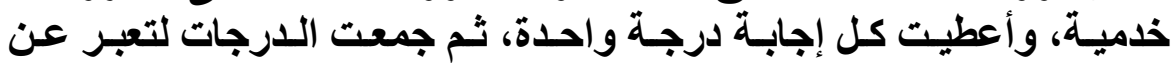

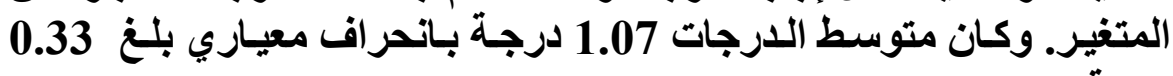
درجة. 


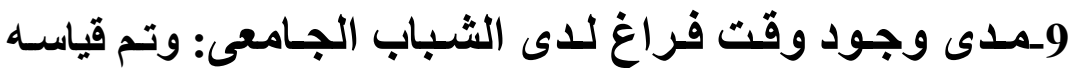

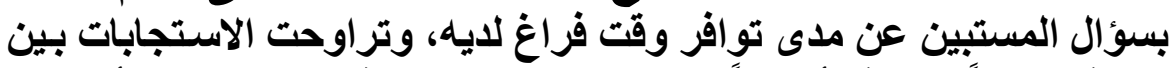

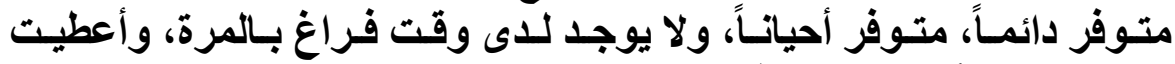

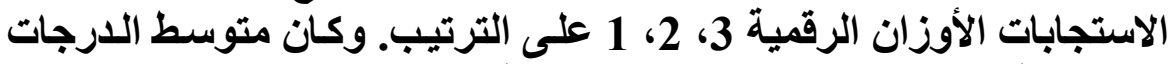
2.3 درجة، بإنحراف معيارى بلغ 6.6 الردرجة.

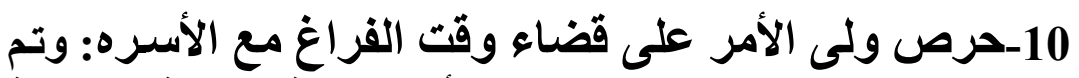

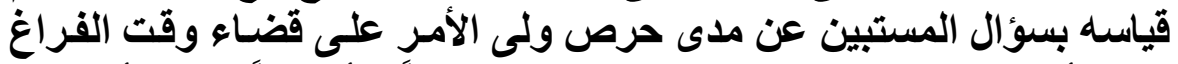

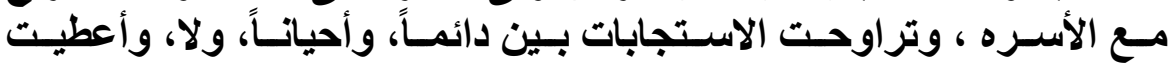

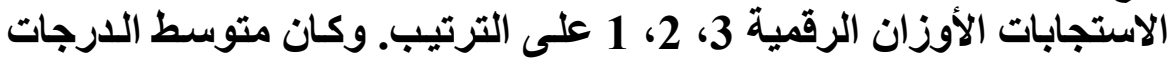
2.06 درجة بإنحر افت معيارى بلغ 0.63 درجة.

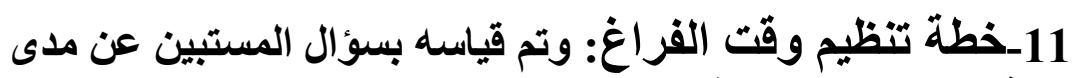

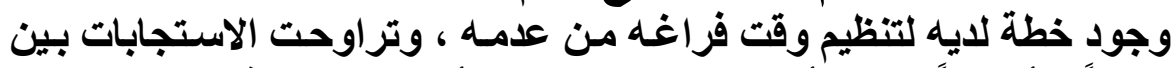

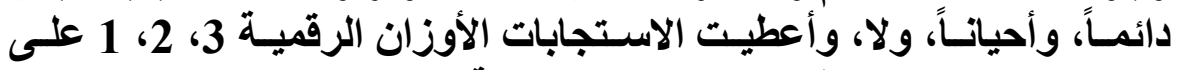
الترتيب. وكان متوسط الدارجات 2.06 درجة بإنحراف معيارى بلغ 20.

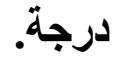

12-إدراك الثباب الجامعى لاهمية الاستفادة من وقت الفراغ:

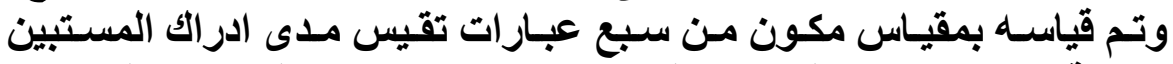

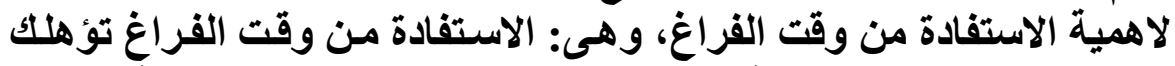

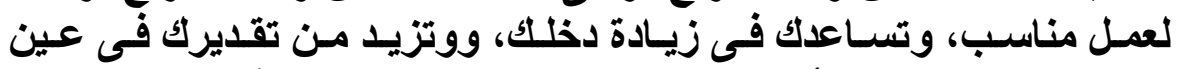

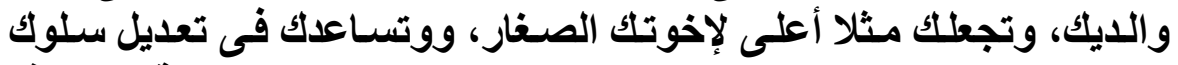

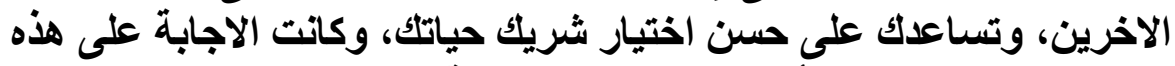

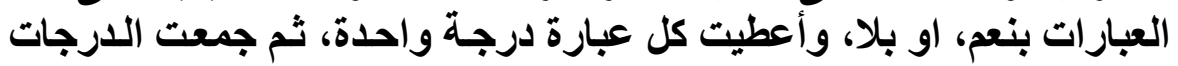
لتعبر عن المتغير. وكان متوسط الدرجات 4.85 درجة بإنحراف معيارى بلغ الغ

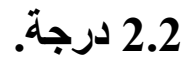

13-عقبات تحول دون الاستفادة من وقت الفراغ: وتم اغت قياسـه

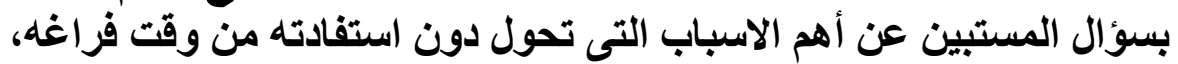

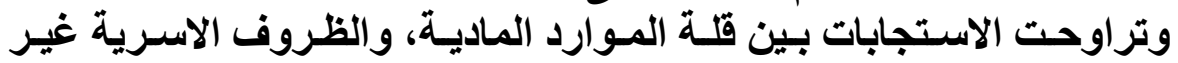

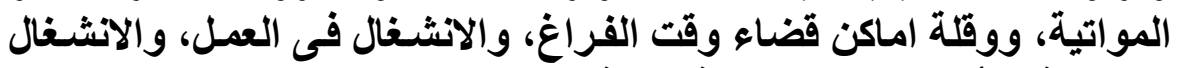

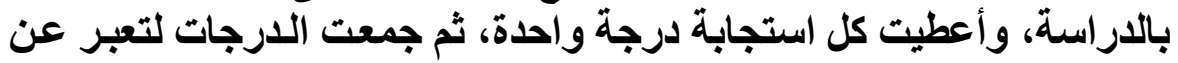

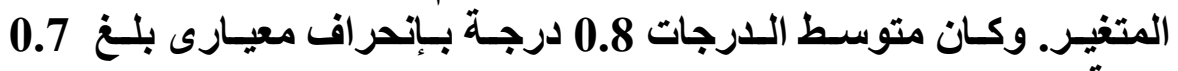


14-المتوسط اليومى لعدد سـاعات مشـاهدة التلفـاز: رقم خـام

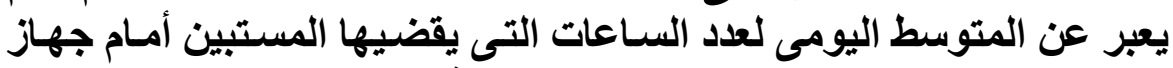

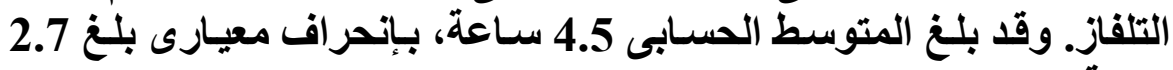

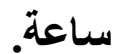

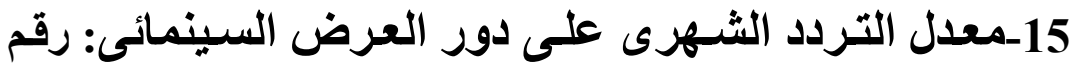

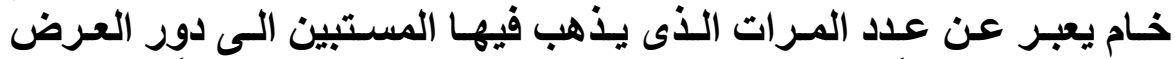

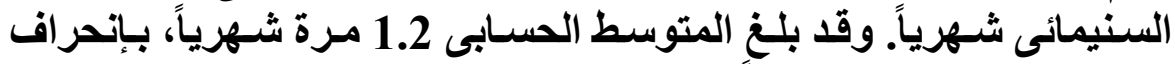
معيارى بلغ 1.1 مرة شهرياً.

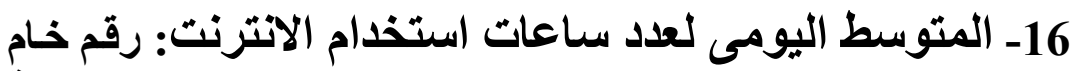

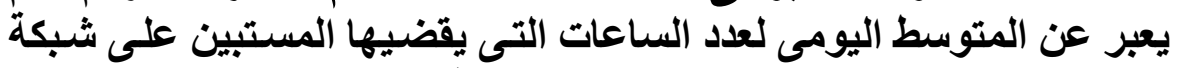
الانترنت. وقد بلغ المتوسط الحسابى 2.6 ساعة، بإنحراف معيارى بلغ النغ 2.3

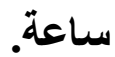

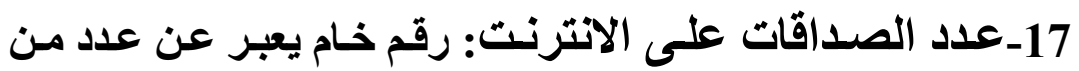

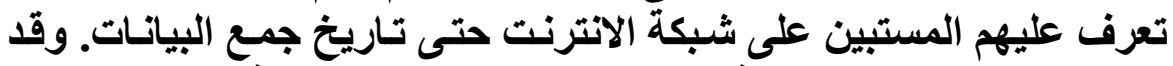
بلغ المتوسط الحسابى 5.8 فرد، بإنحر افت معيارى بلغ 5.4 فرد. ب-قياس المتغيرات التابعة:

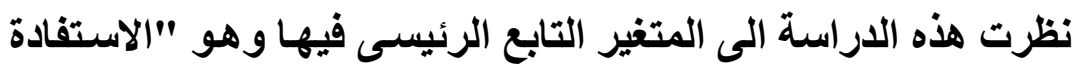

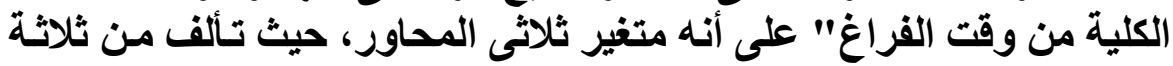

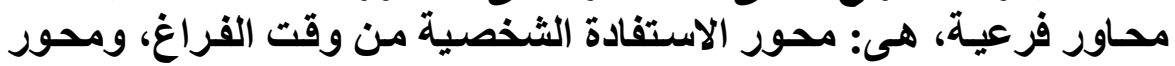

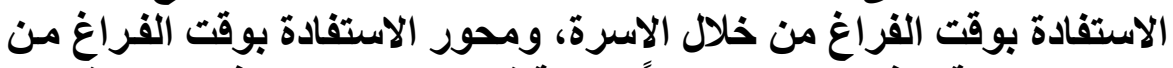

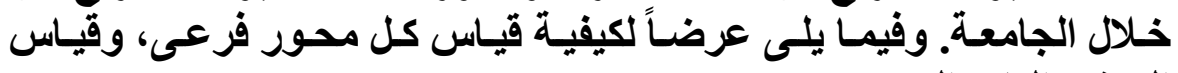

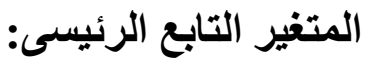
أولاً: محور الاستفادة الشخصية من وقت الرئية الفراغ:

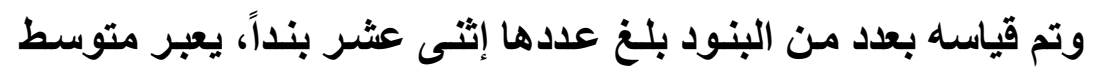

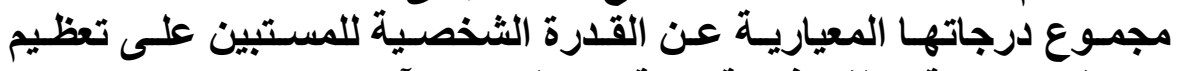
الاستفادة من وقت الفراغ، وقد تم قياس البنود كالآتى:

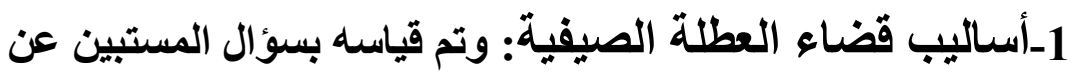

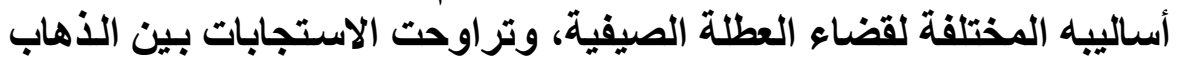

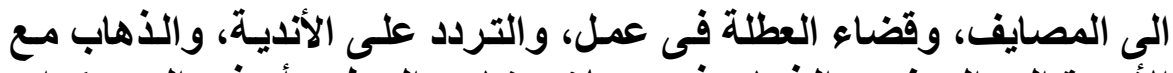
الأسرة الى الريف، والذهاب فى رحلات خـارج الوطن، أو في المعسكرات 
الثبابية الجامعية. وأعطيت كل استجابة درجة واحدة، ثم جمعت الدرجات لتعبر عن المتفير.

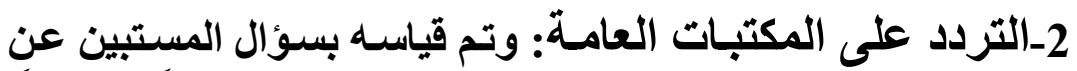

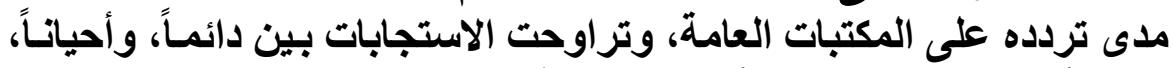
ولا، وأعطيت الاستجابات الأوزان الرقمية 3، 2، 1 على الترتيب.

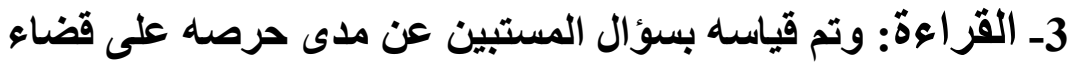

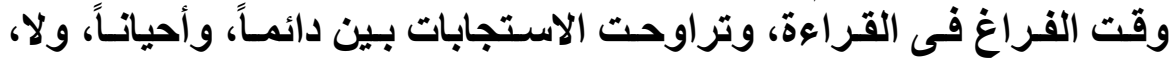
وأعطيت الاستجابات الأوزان الرقمية 3، 2، 1 على الترتيب.

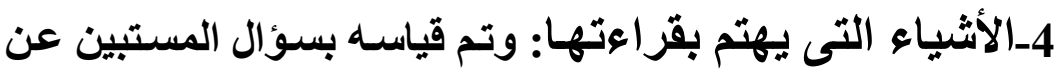

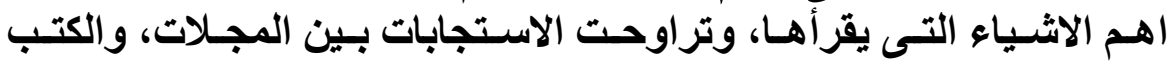

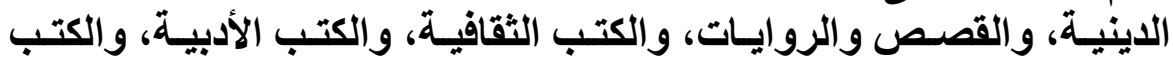

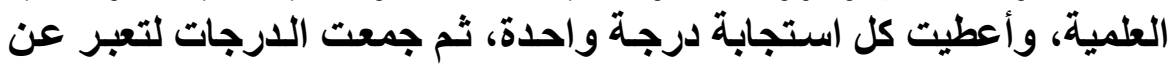

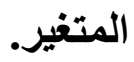

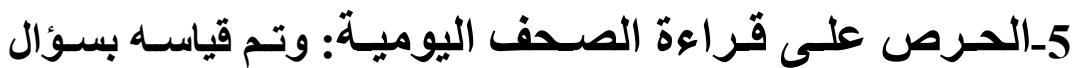

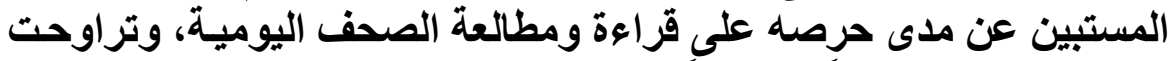

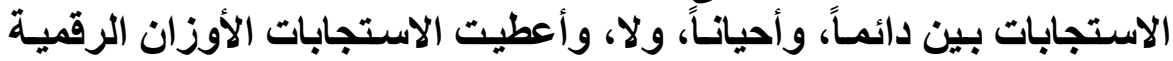

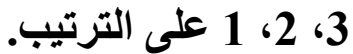

6-اولويـات الموضوعات بالصحف اليوميـة: وتم قياسـه بسؤال

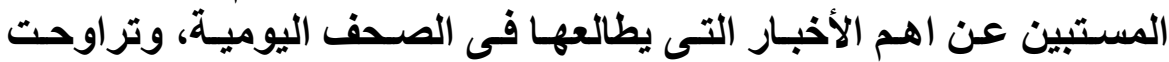

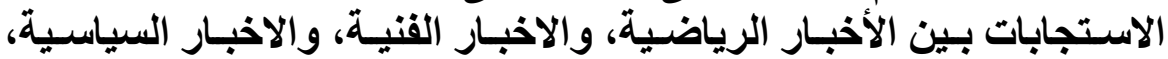

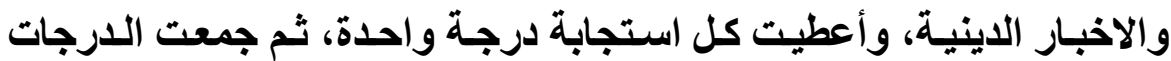

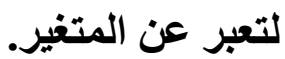

7-الاهتمام بمتابعة الأحداث والاخبـار السياسية العالميسة: وتم

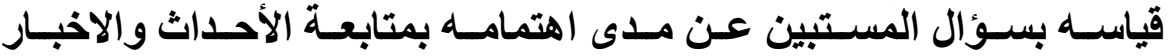

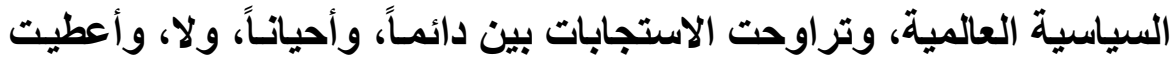
الاستجابات الأوزان الرقمية 3، 2، 1 على الترتيب.

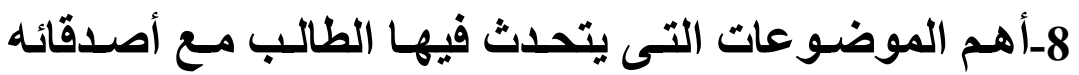

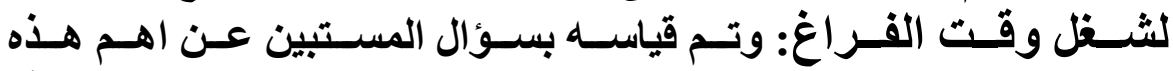

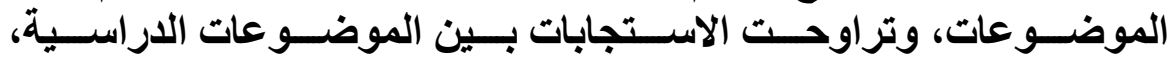

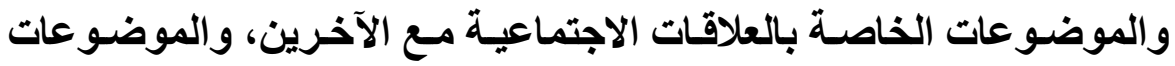


الاينية، وعدم وجود موضوعات محددة، وأعطيت كل استجابة درجة واحدة، ثم جمعت الارجات لتعبر عن المتود عات منغير.

9_النشاط الرياضى: وتم قياسه بسؤال المستبين عن مدى حرصـه

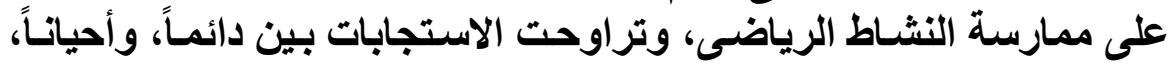
ولا، وأعطيت الاستجابات الأوزان الرقمية 3، 3، 2، 1 على الترتيب.

10-مكان مزاولة النشـاط الرياضسى: وتم قياسـه بسؤال المستبين

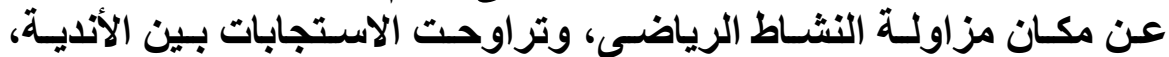

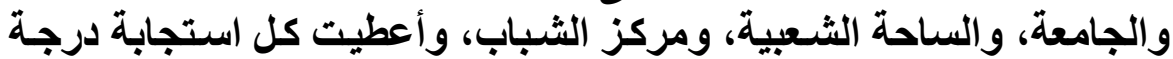
واحدة، ثم جمعت الدرجات والتعبر عن المتغير.

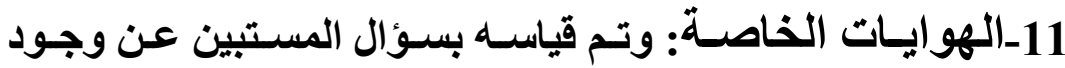

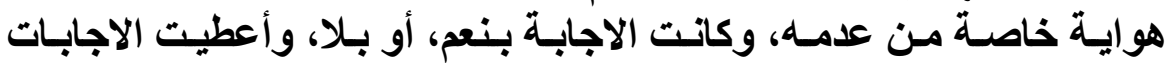

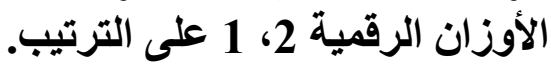

12-توافر الوقت لممارسة الهواية: وتم قياسـه بسؤال المستبين

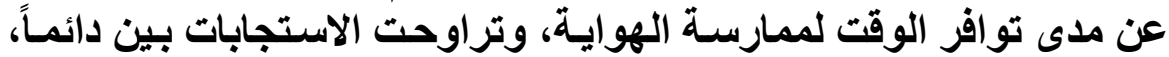

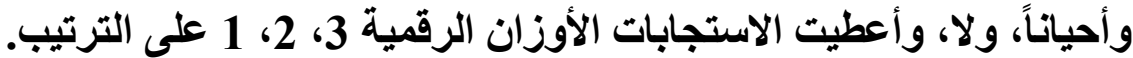
ولما كانت درجات قياس البنود الاثنى عشر مختلفة في وحدات فئ قياسها

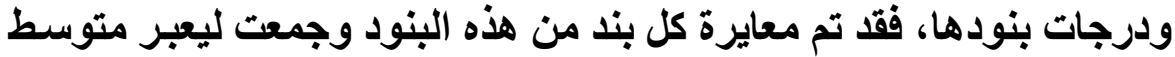

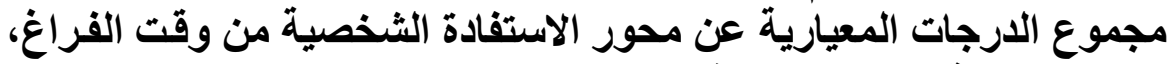
وقد بلغت قيمة معامل ثبات هذا المحور (

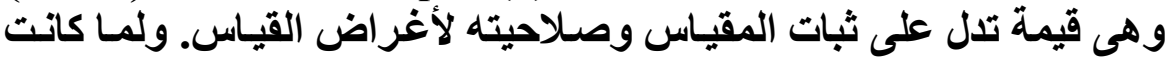

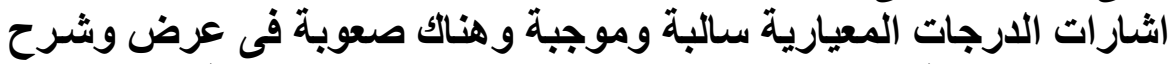

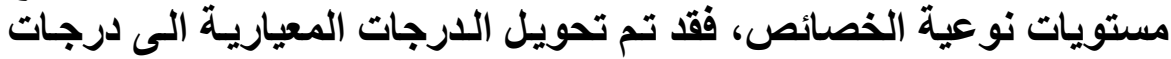

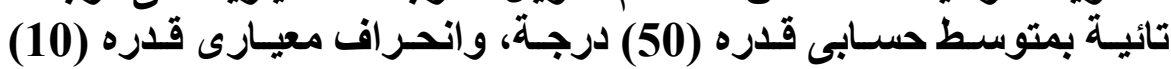

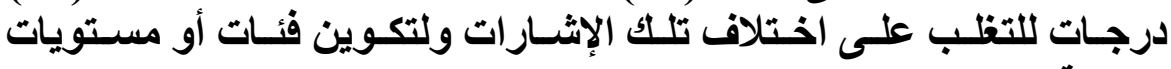
وصفية للمتغير.

ثانياً: محور الاستفادة بوقت الفراغ من خلال الأسرة:

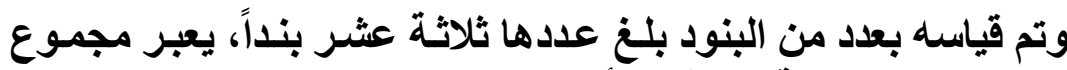

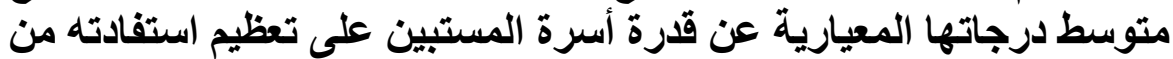
وقت الفراغ، وقد تم قياس البنود كالآتى: 


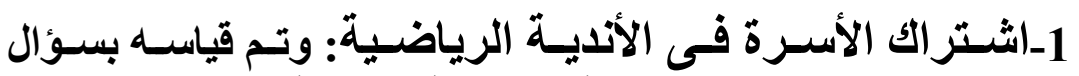

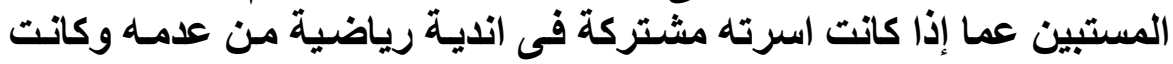

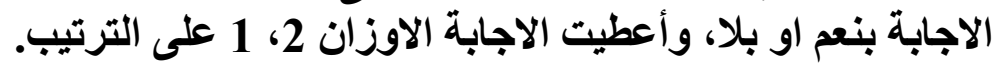

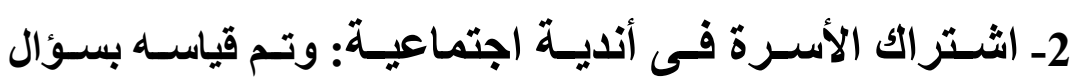

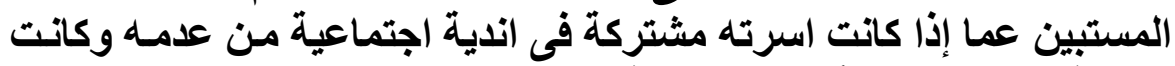

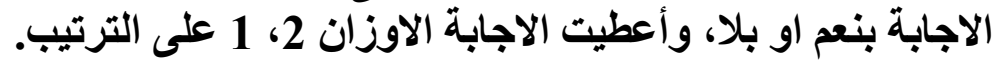

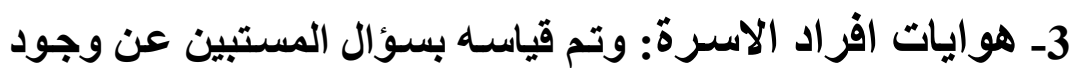

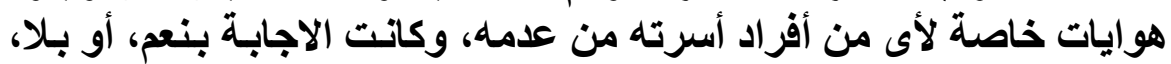
وأعطيت الاجابات الأوزان الرقمية 2، 1 على الترتيب.

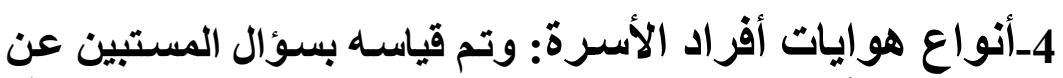

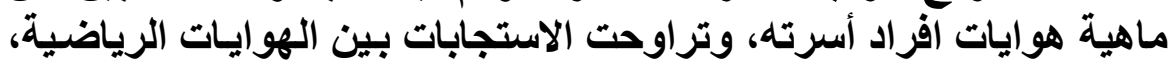

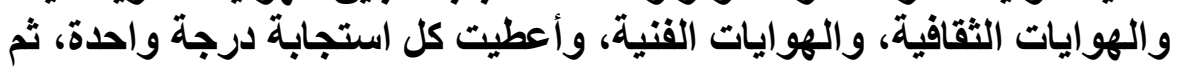
جمعت الارجات لتعبر عن المتغير.

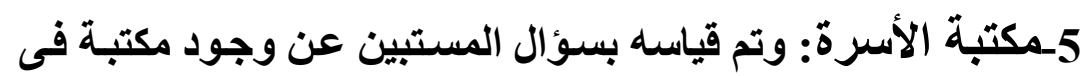

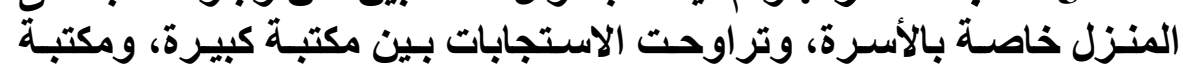

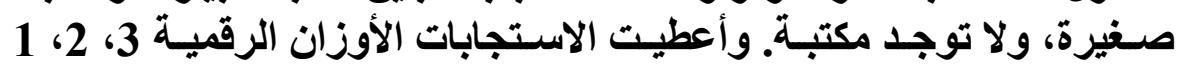

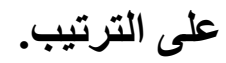

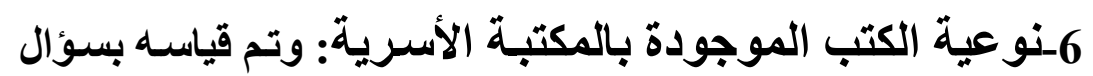

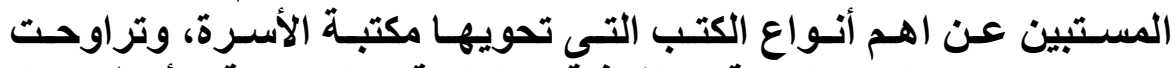

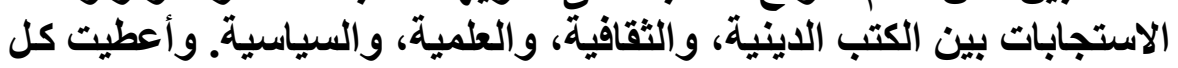
استجابة درجة واحدة، ثم جمعت الارجات لتعبنة والتبر عن المتغير.

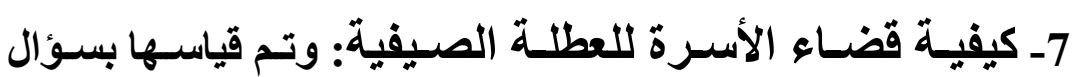

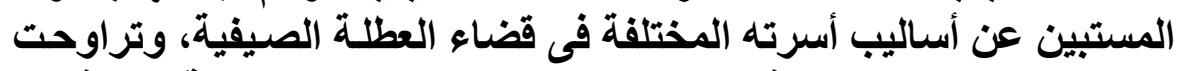

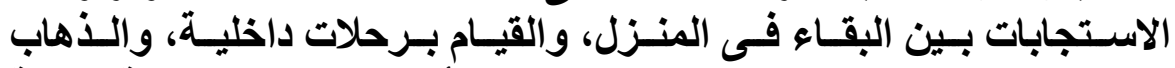

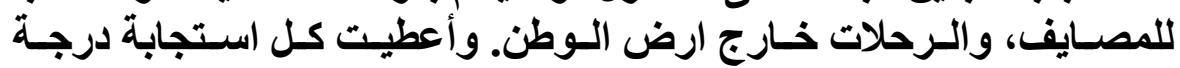
واحدة، ثم جمعت الدرجات لتعبر عن المتغير.

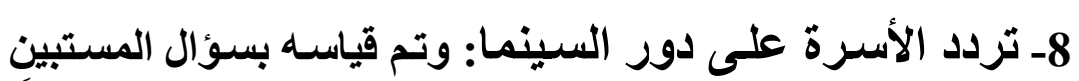

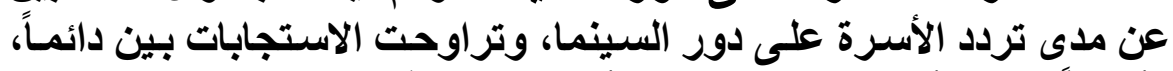
وأحياناً، ولا، وأعطيت الاستجابات الأوزان الرقمية 3، 2، 1 على الترتيب. 


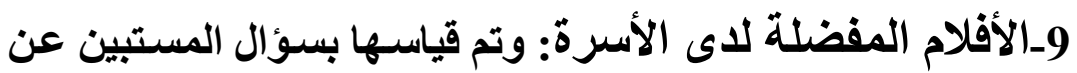

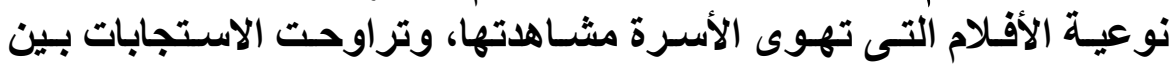

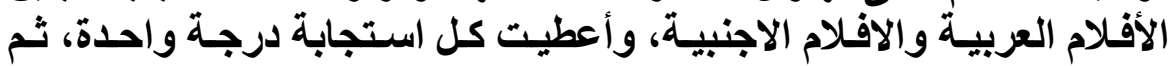
جمعت الارجات لتعبر عن المتغير.

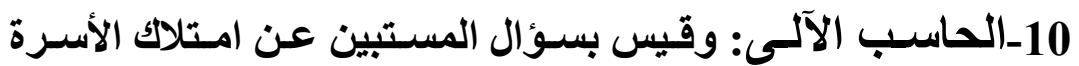

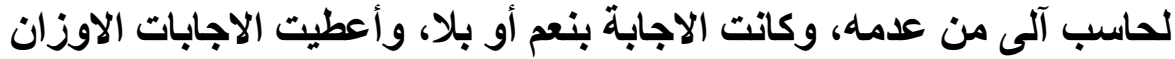
الرقمية 2، و 11 على الترتيب.

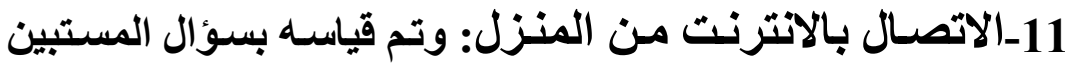

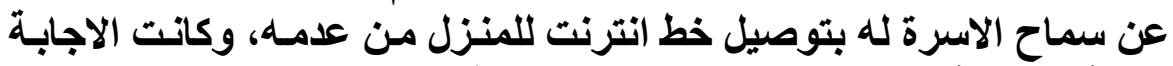
بنعم أو بلا، وأعطيت الاجابات الاوزان الرقمية 2، و1 على الترتيب.

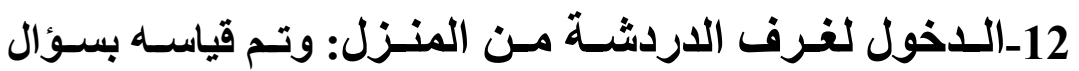

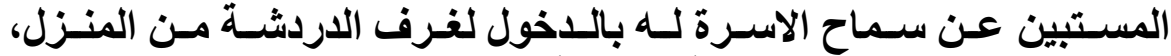
وتراوحت الاستجابات بين دائماً، وأحياناً، ولا، وأعطيت الاستئن الاستجابات الأوزان الرقمية 3، 2، 1 على الترتيب.

13-السماح بتكوين صداقات على الانترنت: وتم قياسـه بسؤال

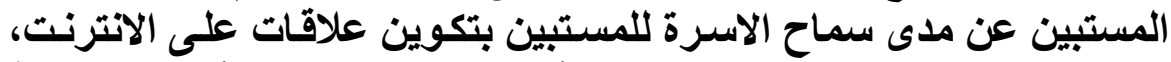
وتراوحت الاستجابات بين نعم، ولا، وأعطيت الاستجابات الأوزان الرقميـة

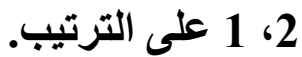

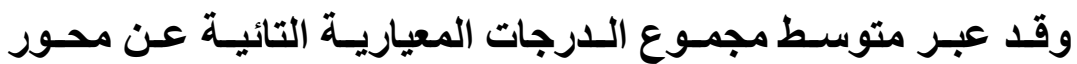

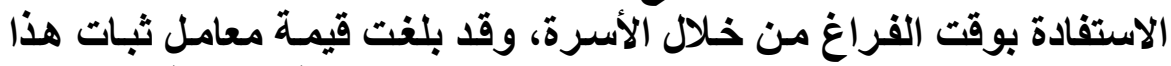
المحور( ثبات المقياس وصلاحيته لأغراض القياس. ثالثاً: محور الاستفادة بوقت الفراغ من خلادل الجامعانة

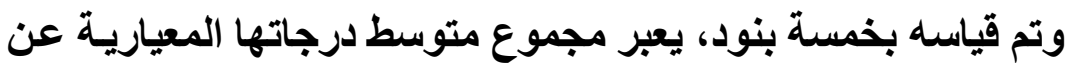

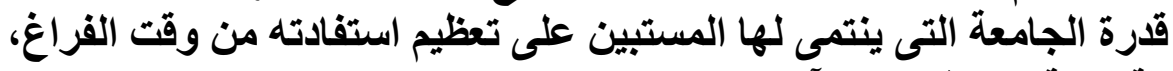

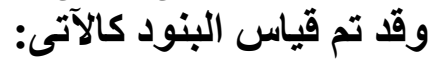

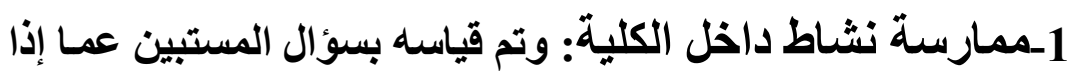

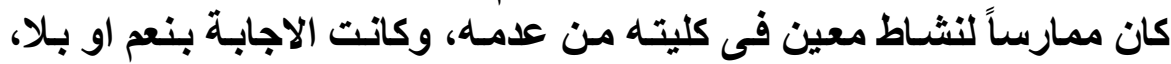
وأعطيت الاجابة الاوزان 2، 1 على الترتيب. 


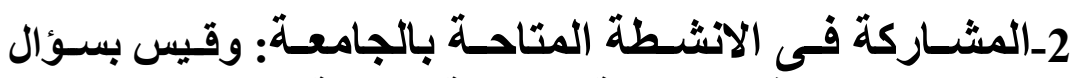

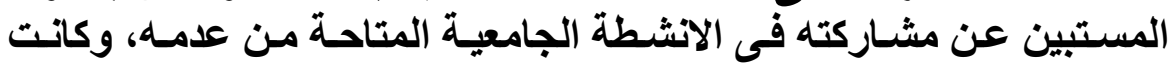
الاجابة بنعم او بلا، وأعطيت الاجابة الاوزان الرقية الجمية 2، و 1 على الترتيب.

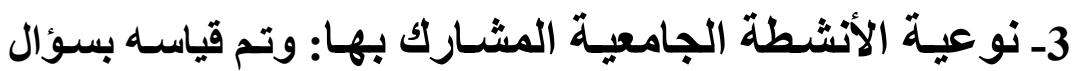

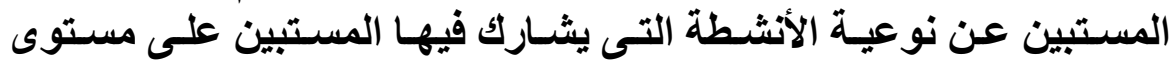

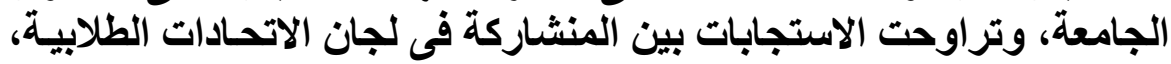

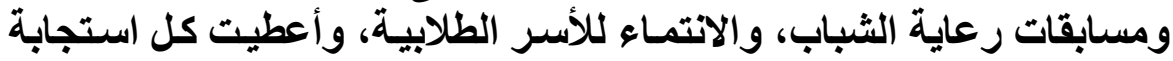
درجة واحةة، ثم جمعت الدرجات لتعبر عن المتغير.

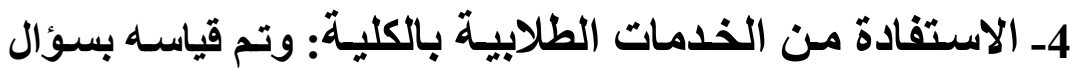

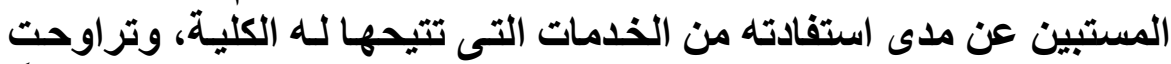

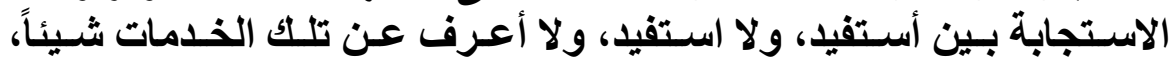
وأعطيت الاستجابات الأوزان الرقمية 3، 2، 1 الاعلى الترتيب.

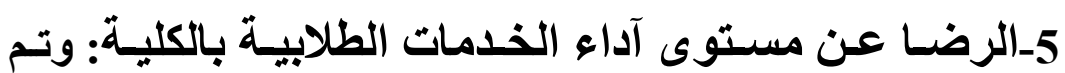

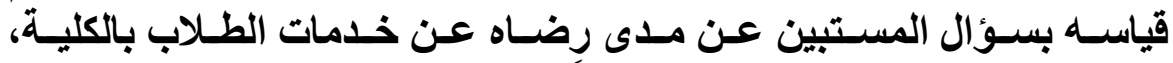

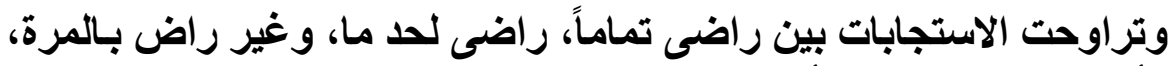
وأعطيت الاستجابات الأوزان

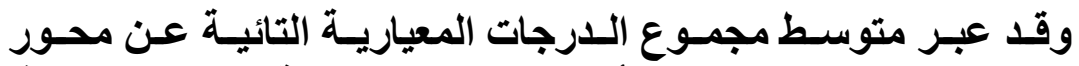

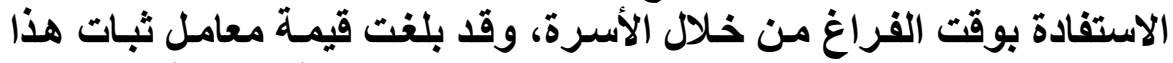

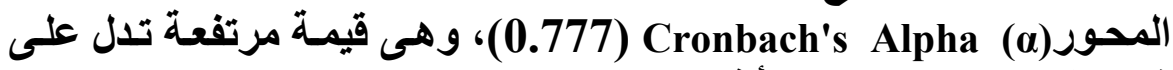
ثُبات المقياس وصلاحيته لأغراض القياس.

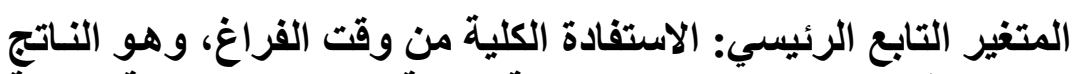
النهائى لمتوسط مجموع الارجات المعيارية التائية للمحاور الفرعية الفية الثلاثئة

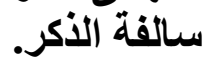
ثالثاًَ: أسلوب جمع البيانات الميدانية:

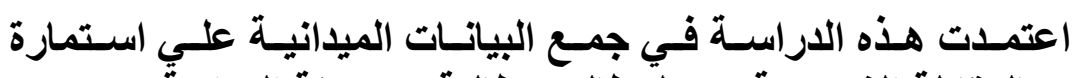

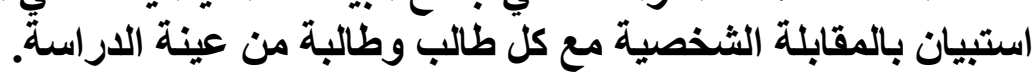
رابعاًَ: الاختبار المبلئي لاستمارة الاستبيان:

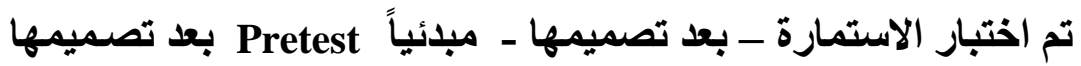
علي عينة مكونة من عشرين طالبا وطالبة من خارج عينة الدراسة، حيث تم 
تعديل بعض الأسئلة وإعـادة صباغة بعضـها كمـا تم حذف بعض الأنس الأسئلة

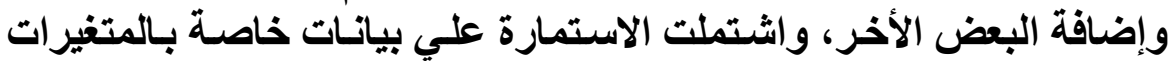
البحثية المستقلة والتابعة.

خامساً: الفروض البحثة البهية

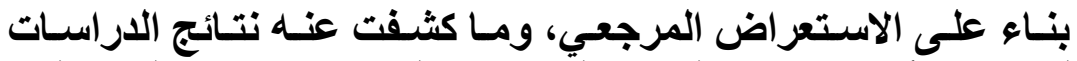

السابقة، ووفقا لأهداف الاراسة الحالية تم صياغة الفروض البحثيّة الآتية:

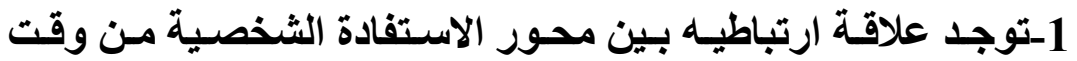

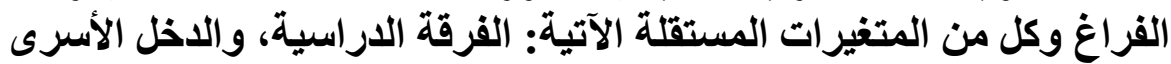

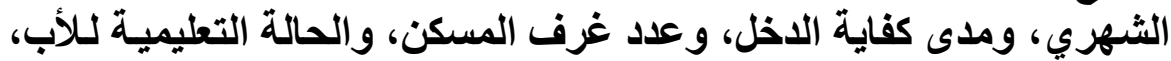

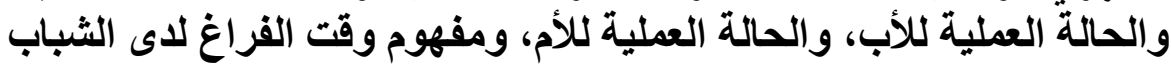

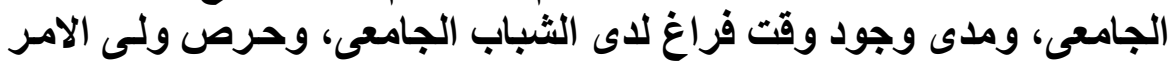

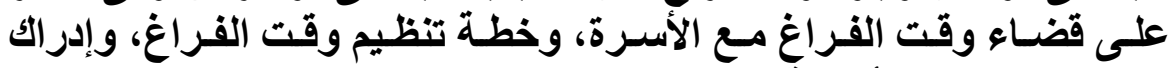

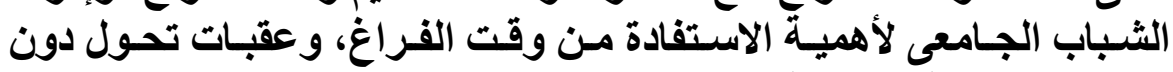

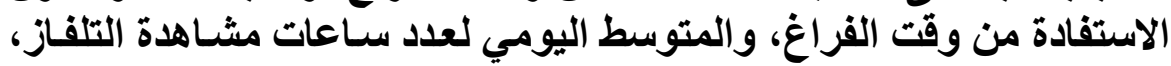

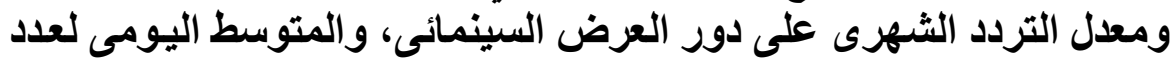
ساعات إستخدام الانترنت، وعدد الصداقات دور على الانترنت.

2-تسهم المتفيرات المستقلة السبعة عشر سالفة الذكر إسهاماً معنوياً

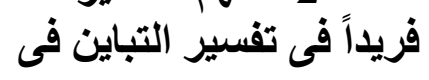

محور الاستفادة الشخصية من وقت الفراغ.

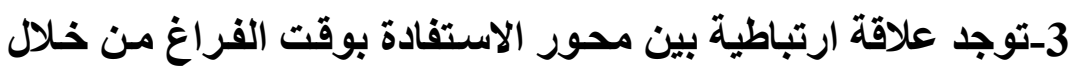

الأسرة وبين المتغيرات المستقلة السبعة عشر سالفة الذكر كل على حداه

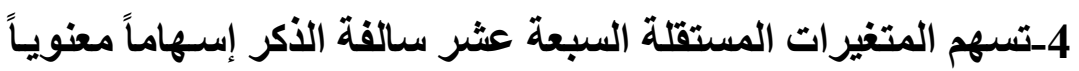

فريداً فى تفسير التباين فى محور الاستفادة بوقت الفراغ الفئ من خلال الأسرة.

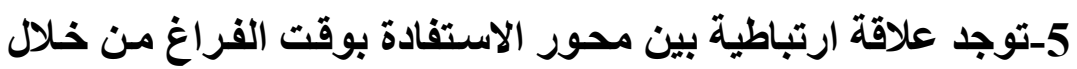

الجامعة وبين المتفيرات المستقلة السبعة عشر سالفة الذكر كل على حداده

6-تسهم المتفيرات المستقلة السبعة عثر سالفة الذكر إسبهاماً معنوياً

فريداً في تفسير التباين في محور الاستفادة بوقت الفراغ المعن من خلال الجامعة.

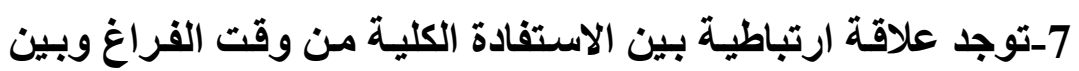

المتغيرات المستقلة السبعة عشر سالفة الذكر كل على حذه. 
8-تسهر المتغيرات المستقلة السبعة عثر سالفة الأكر إسـهاماً معنوياً

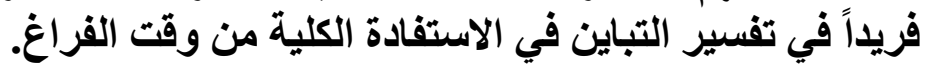

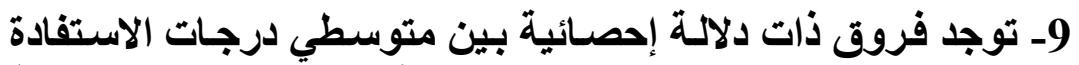
الكلية من وقت الفراغ بين طلاب الكليـات العملية وطلاب الكليات النظريـة

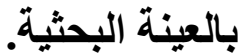

\section{سادساً: الأساليب الإحصائية المستخدمة}

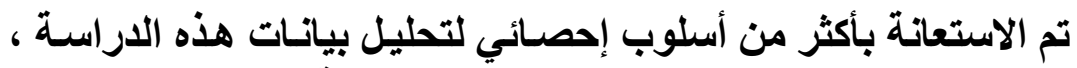

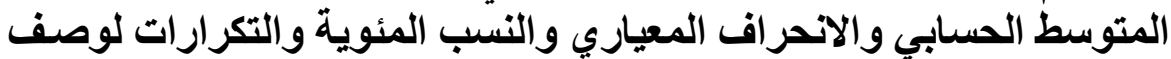

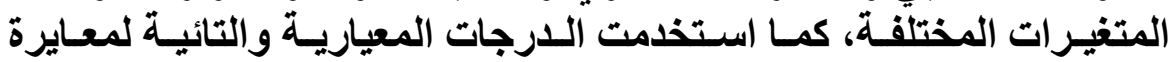

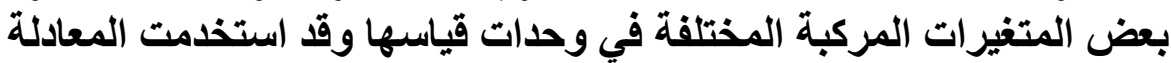

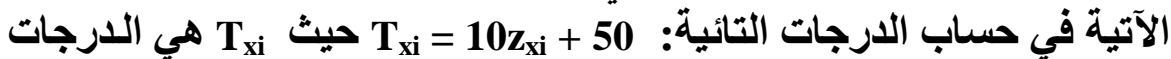

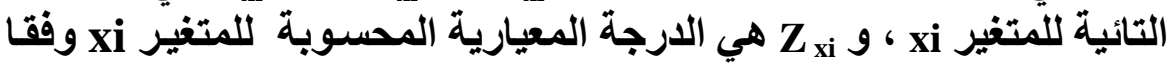

للمعادلة الآتية : لاليفير ،

حيث Xi $Z_{\text {xi }}=x i$ - xi/ SD الحسابي ، SD هي الانحراف المعياري (علام،

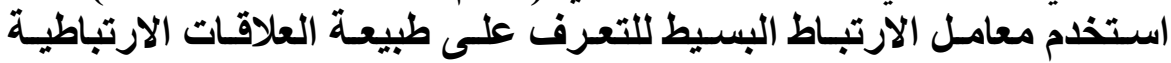

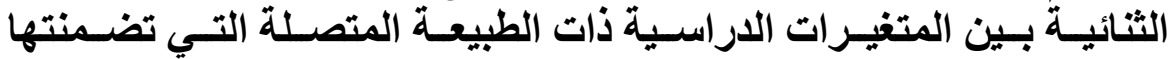

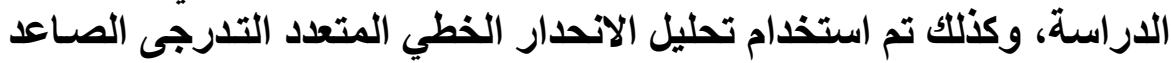
(ألفـاع)

كمـا اسـتخدم معامـل ثبـات كرونبـاخ Cronbach's Alpha (a)

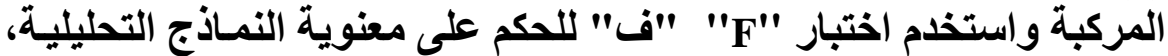

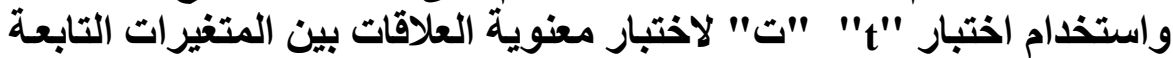

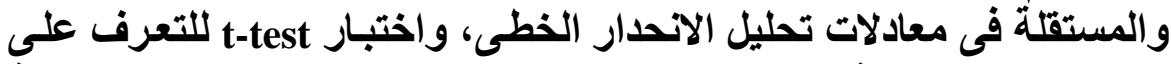

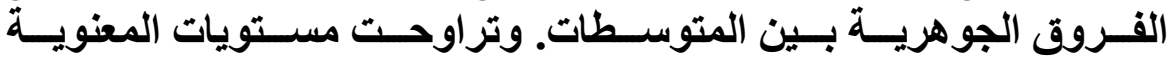

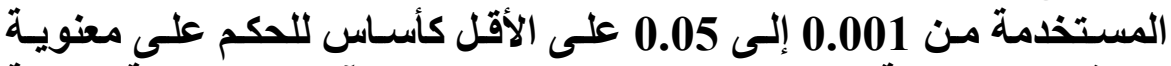

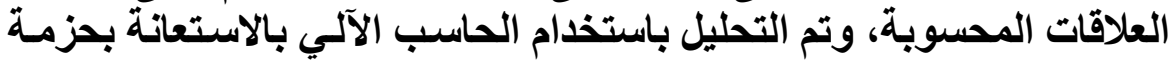

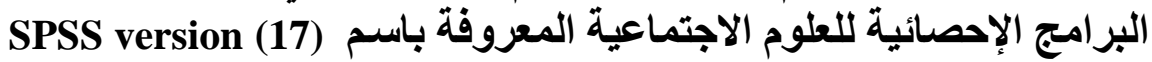
فى المعالجة الإحصائية لبيانات الاراسة.

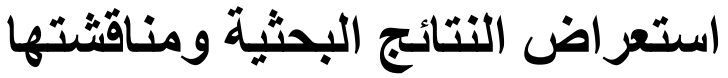
أـاستعراض النتائج البحثية: أولاً: وصف أهم ملامح عينة الدراسة: 
يوضـح الجدول المتـــ رقم (1) النتائج المتعلقة بوصف أهم ملامسح

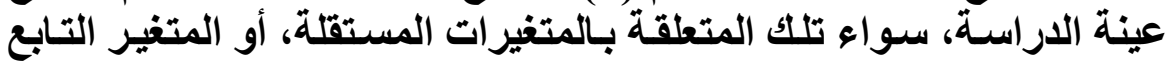

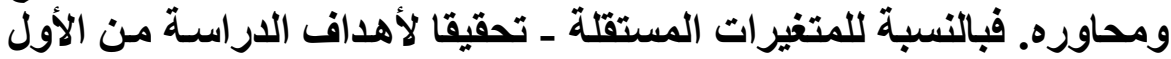

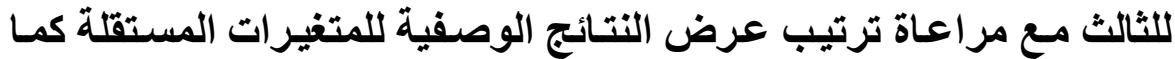

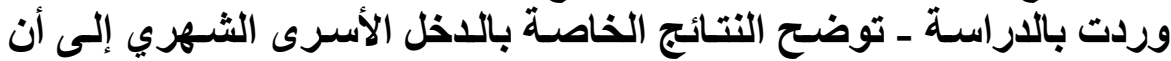

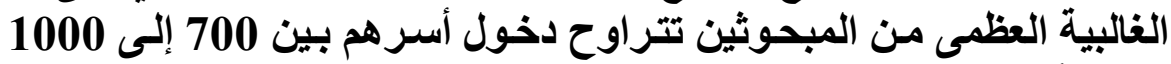

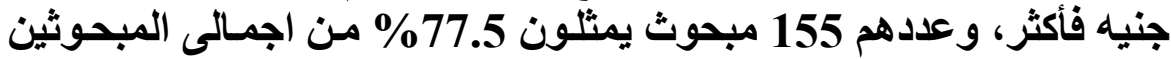

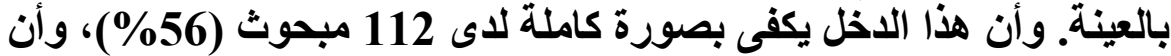

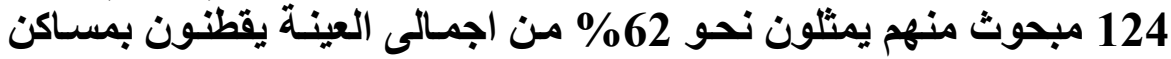

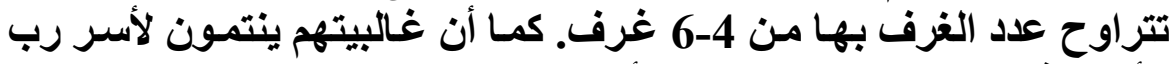

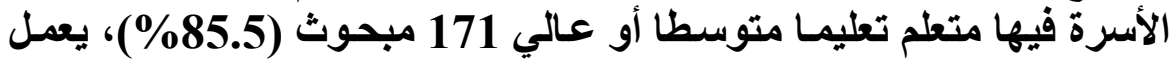

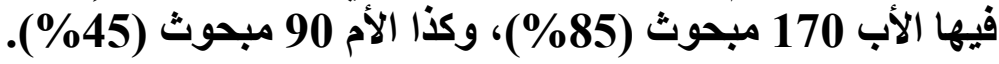

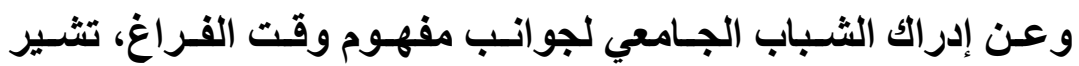

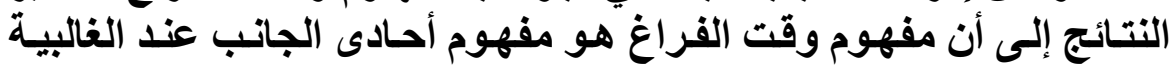

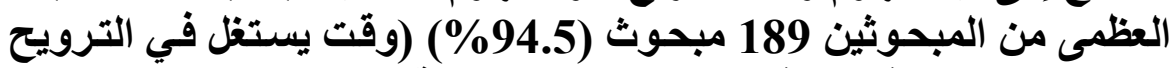

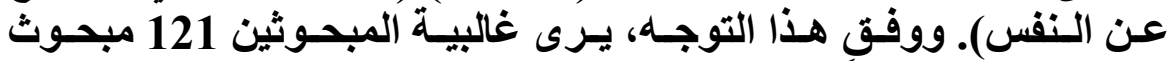

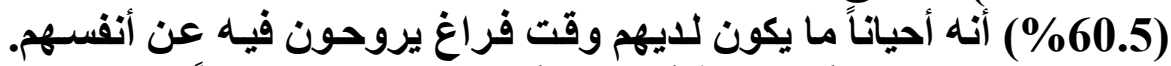

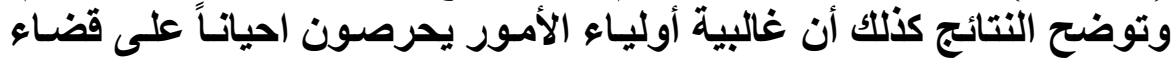
وقت الفراغ مع الأسرة 120 مبحوث (60\%) (610)، كذلك فِإن غالبيـة المبحوثين 102 مبحوث (51\%) يضعون خططاً لتنظيم أوقات فراغهر.

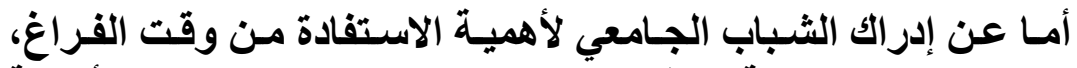

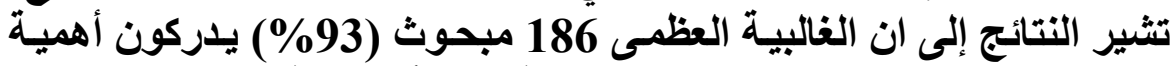

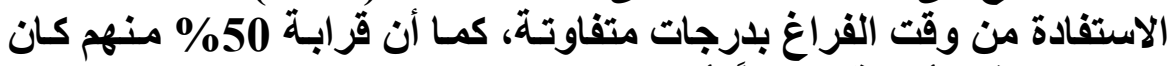

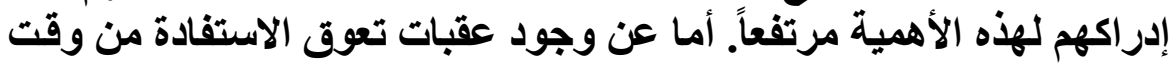

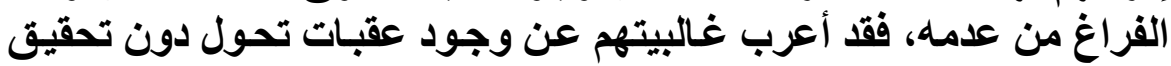

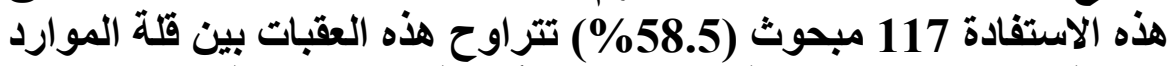

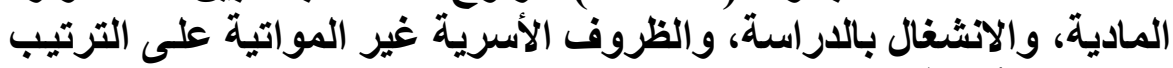
من حيث الأهمية.

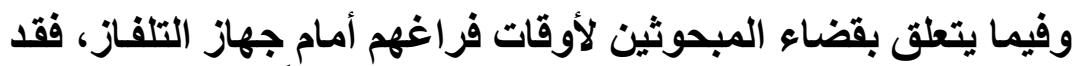

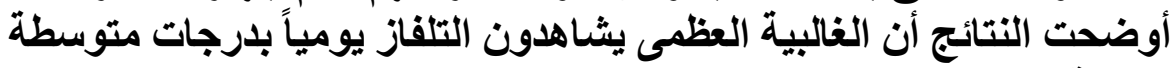

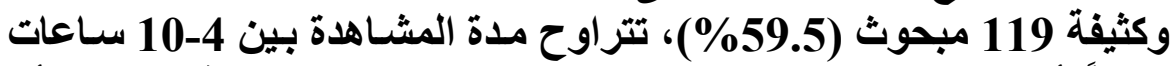

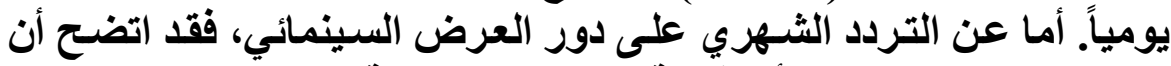
97 مبحوث (48.5\%) (أى قرّابة نصف حجم العينة) لا يترددون على دور العرد 
السينما مطلقاً، أما النسبة الباقية والتي تمثل الغالبية فيإنهم يترددون بثكيل

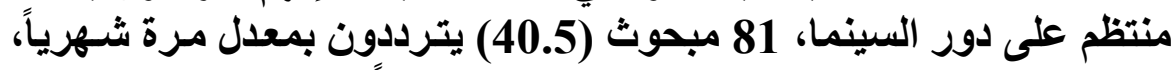

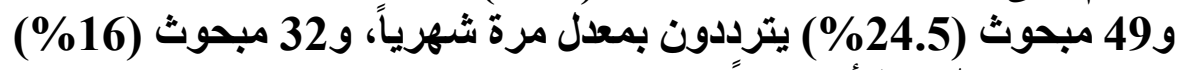
يتردون بمعدل مرة أسبوعياً. 


\section{جدول (1): النتائج الوصفية للاراسة}

أ-وصف المتغيرات المستقلة

\begin{tabular}{|c|c|c|c|}
\hline$\%$ & 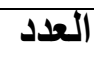 & فئات المتغير & م \\
\hline & & الفرقة الدراسية & 1 \\
\hline 29.5 & 59 & الاولى & \\
\hline 22 & 44 & الثانية & \\
\hline 18.5 & 37 & التّالثَّة & \\
\hline 30 & 60 & الرابعة - ابع & \\
\hline 100 & 200 & المجموع & \\
\hline $\begin{array}{c}16 \\
6.5 \\
21.5 \\
56 \\
\end{array}$ & $\begin{array}{r}32 \\
13 \\
43 \\
112 \\
\end{array}$ & 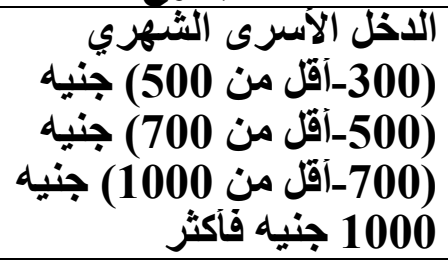 & 2 \\
\hline 100 & 200 & المجموع & \\
\hline
\end{tabular}

\begin{tabular}{|c|c|c|c|}
\hline $\begin{array}{c}9.5 \\
35 \\
55.5 \\
\end{array}$ & $\begin{array}{c}19 \\
70 \\
111\end{array}$ & 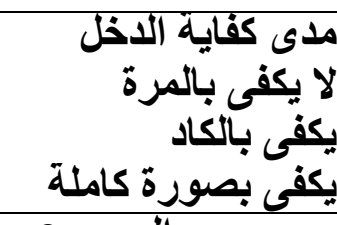 & 3 \\
\hline 100 & 200 & المجموع & \\
\hline & & عدد غزف المسكن & 4 \\
\hline 38 & $\begin{array}{c}76 \\
124\end{array}$ & 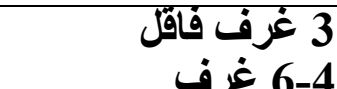 & \\
\hline 100 & 200 & المجموع & \\
\hline & & الحالة التعليمية للآب & 5 \\
\hline 3 & 6 & & \\
\hline 11.5 & 23 & تعليم دون المتوسط & \\
\hline 85.5 & 171 & تطليم متوسط آو عالي & \\
\hline 100 & 200 & المجموع & \\
\hline & & الحالة العملية للاب & 6 \\
\hline 2.5 & 5 & متوفى & \\
\hline 12.5 & 25 & & \\
\hline 85 & 170 & يعمل & \\
\hline 100 & 200 & المجموع & \\
\hline
\end{tabular}

تابع: جدول (1) 


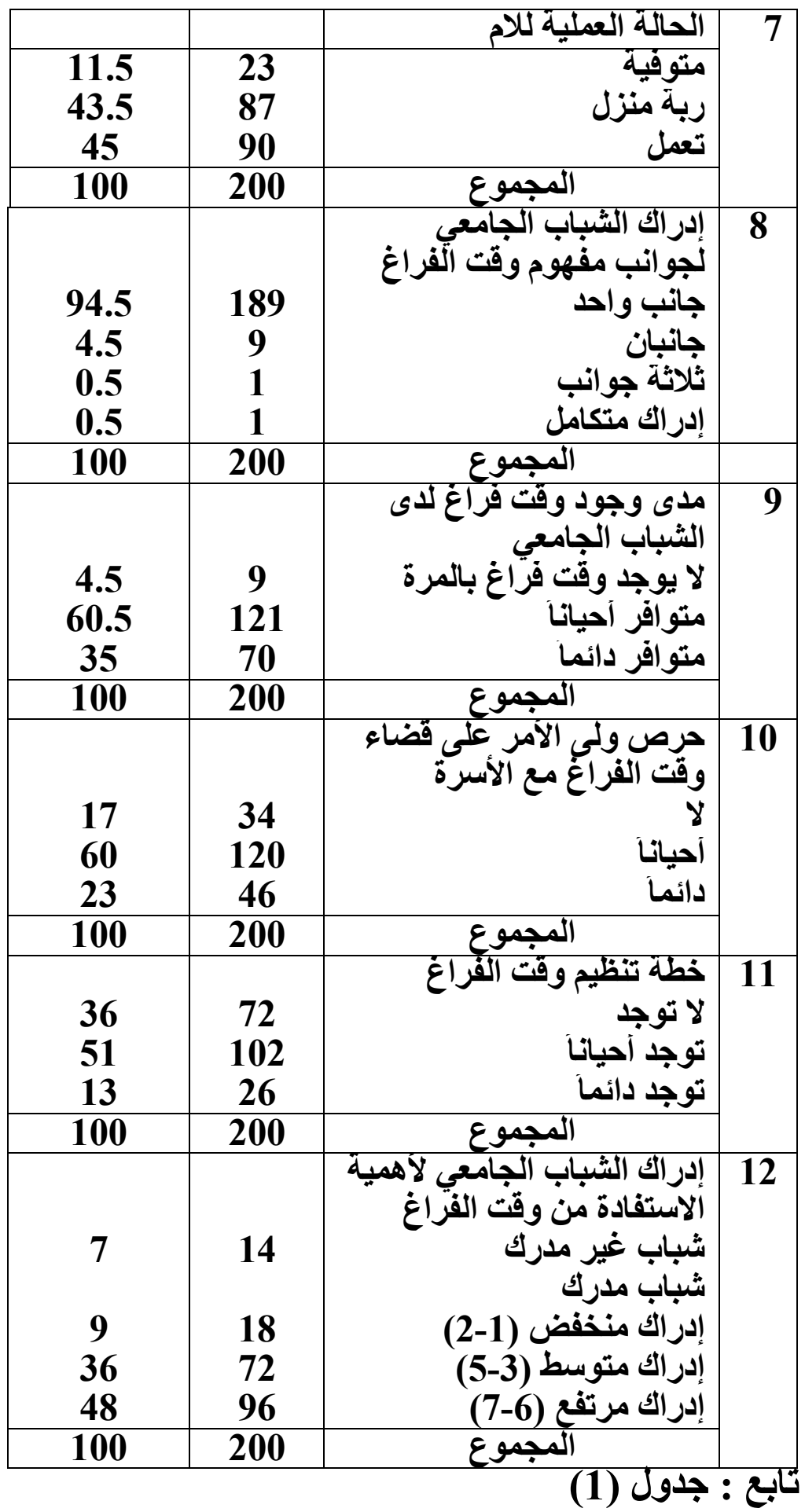




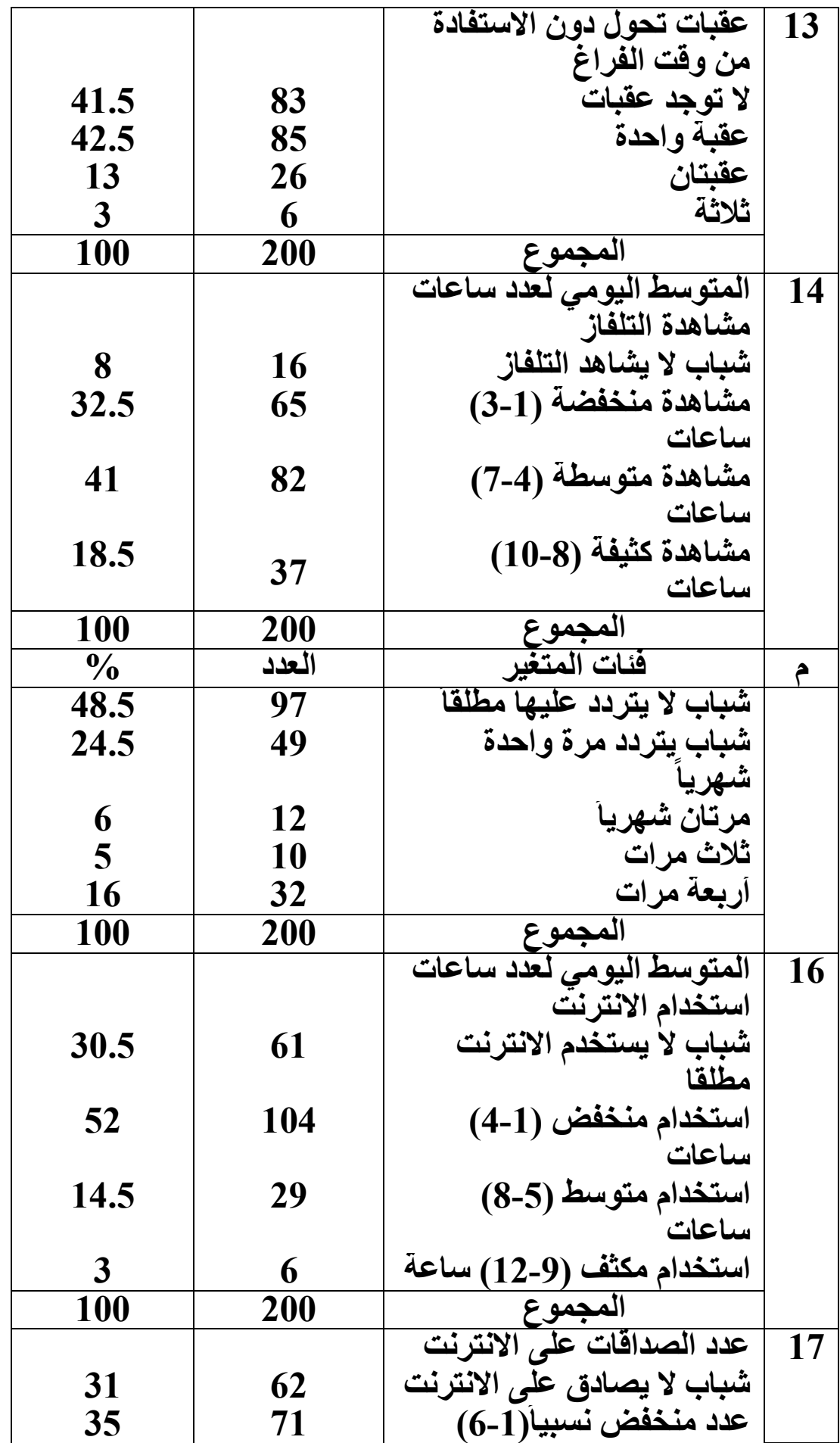




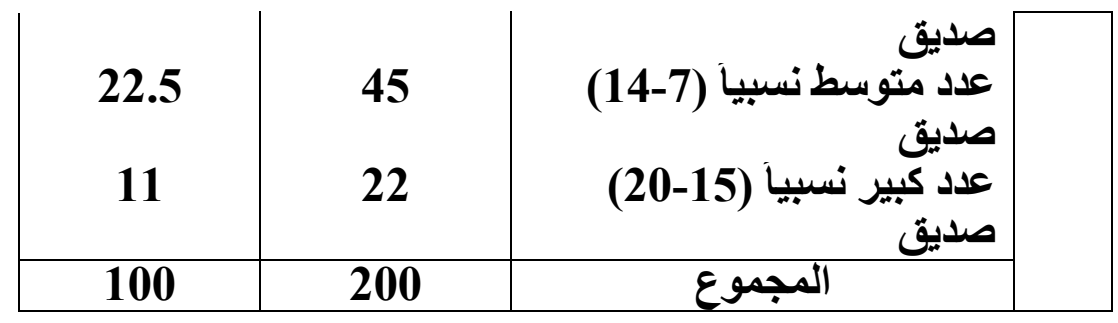




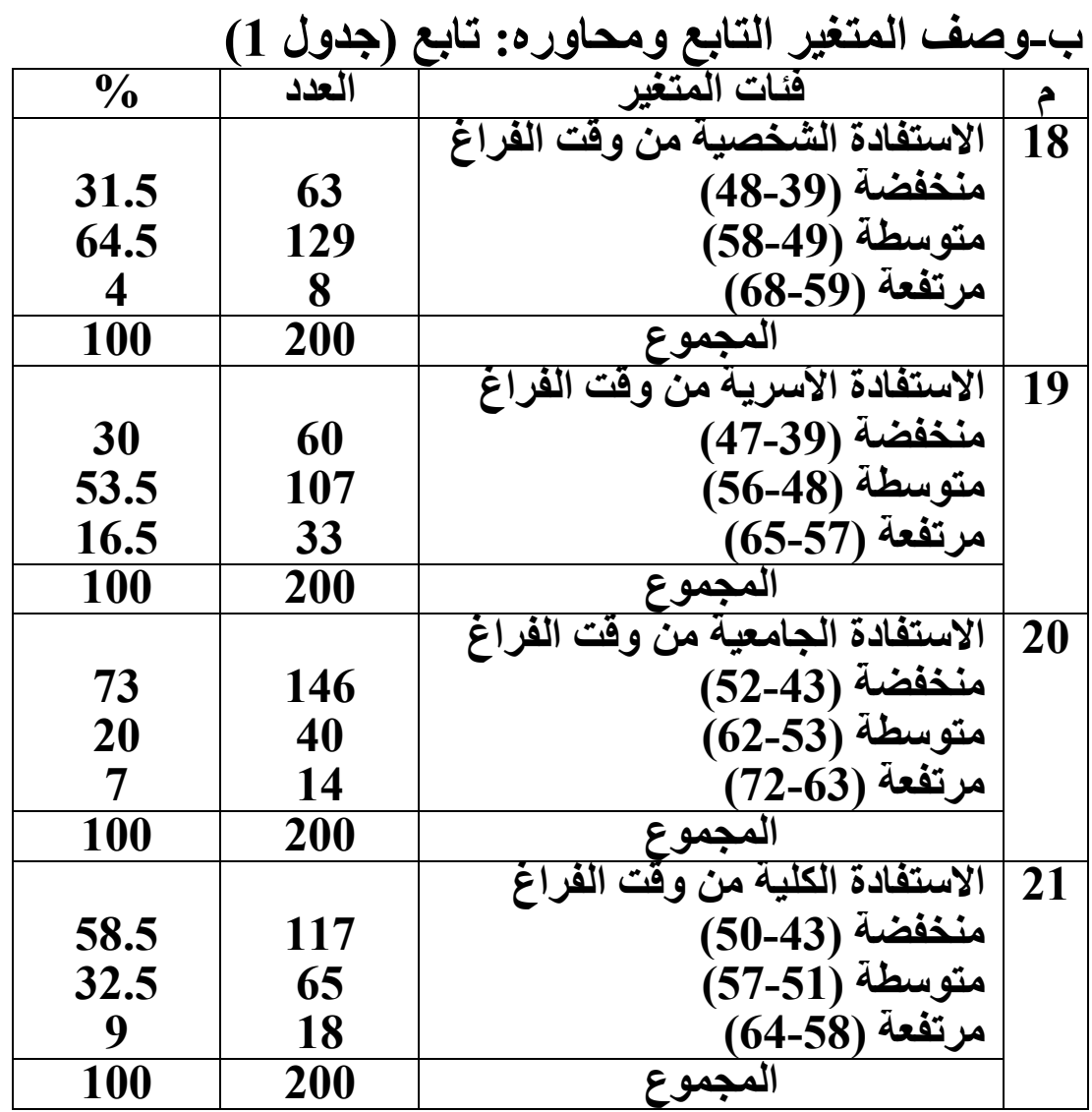

المصدر: جمعت وحسبت من بيانات الدراسة

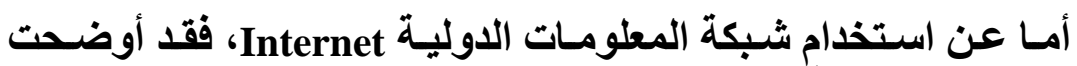

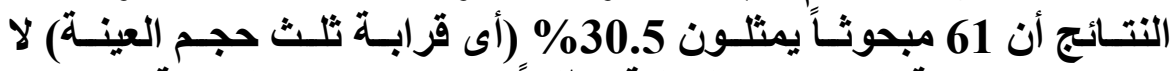

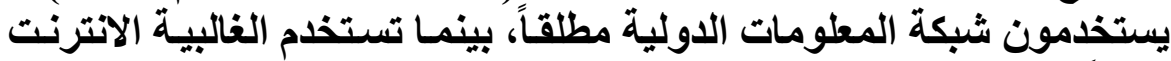

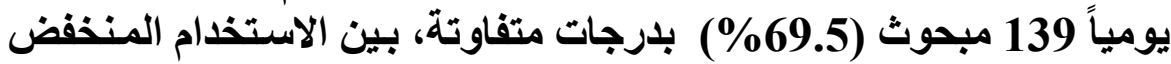

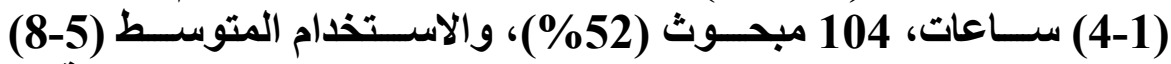

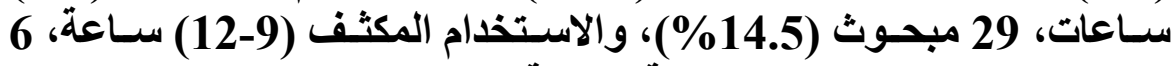
مبحوثين (\%3) من اجمالى العينة البحثية.

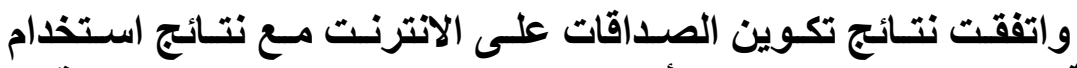

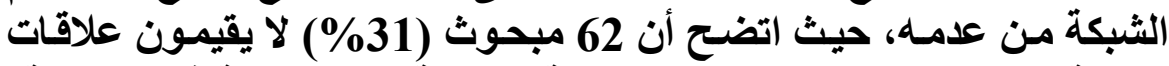

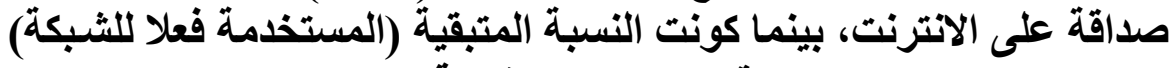
138 مبحوث (\%69) صداقات بلاترنات منفاوتة. 
أما بالنسبة للمتغير التابع ومحاوره، فقد أوضحت نتائج نفس الجدول

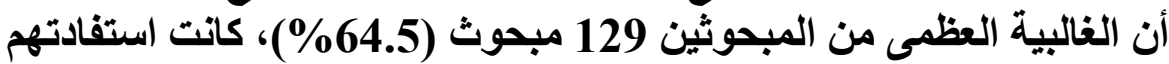

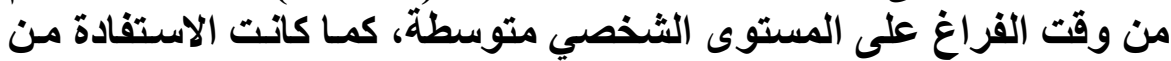

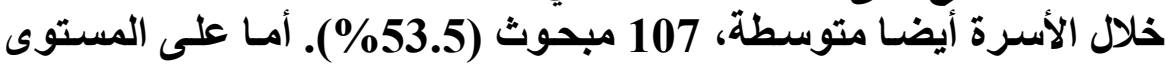

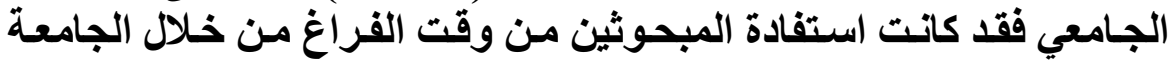
منخفضة، 146 مبحوث (73\%).

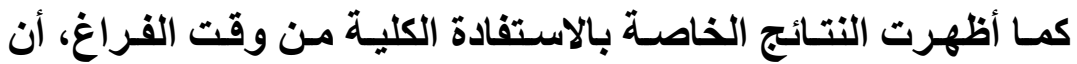

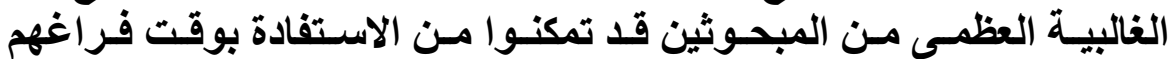

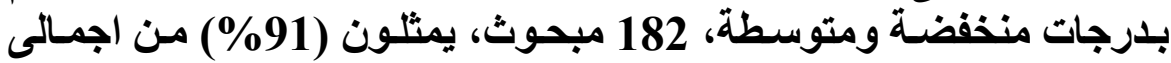
المبحوثين بالعينة.

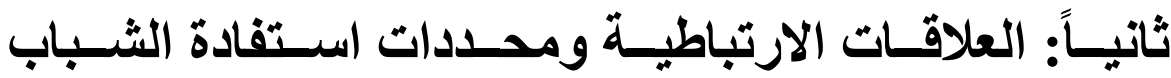

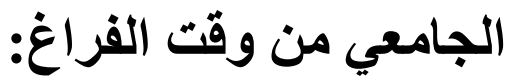

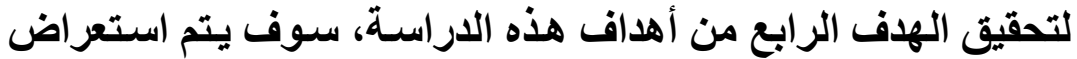

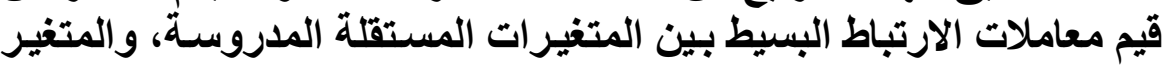
التابع الرئيسي ومحاوره الثلاثة، وكذا الوقوف عليرات الهى أهم محددات الاستفادة

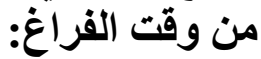

1-العلاقـات الارتباطيـة ومحددات الاستفادة الثخصية مـن وقت

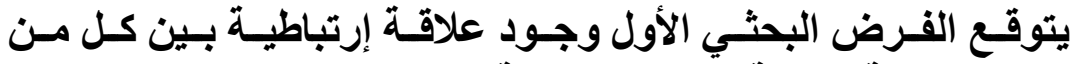

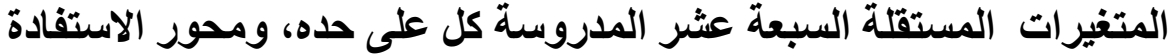

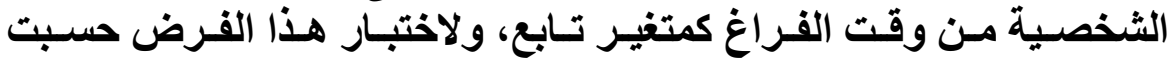

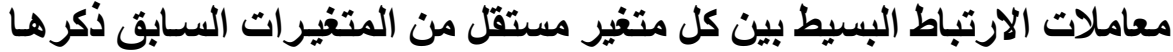
وبين محور الاستفادة الشخصية من وقت الفراغ.

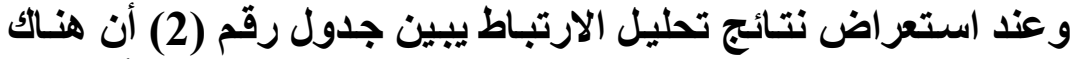

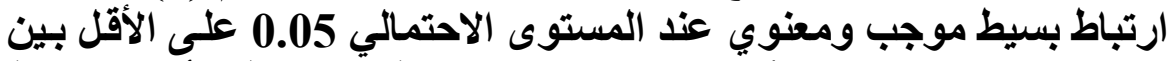

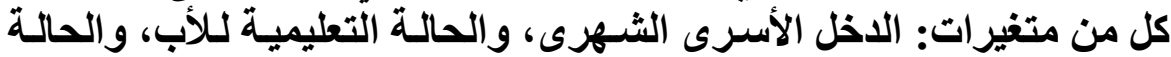

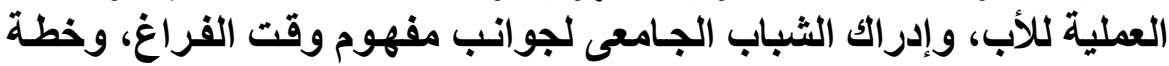

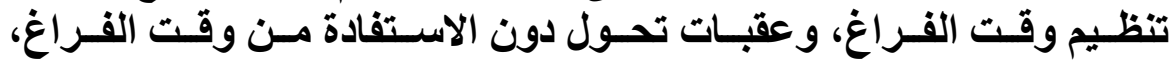

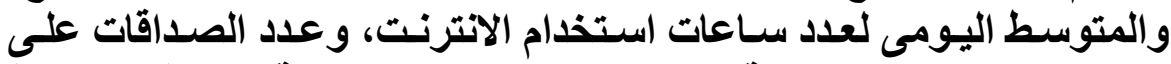

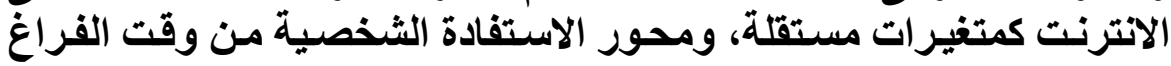

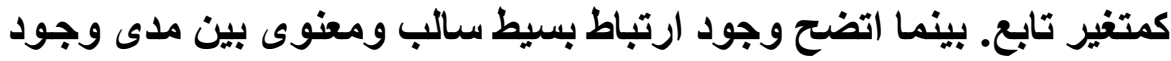




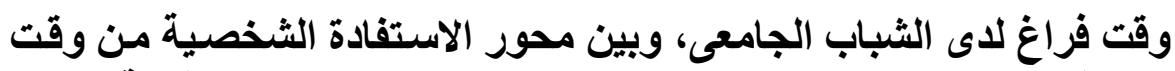

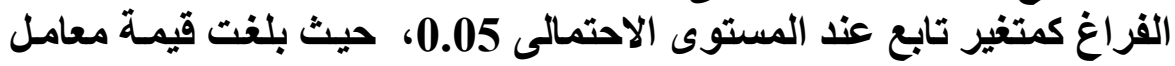

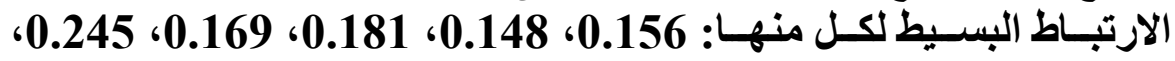

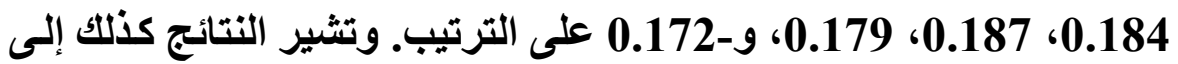

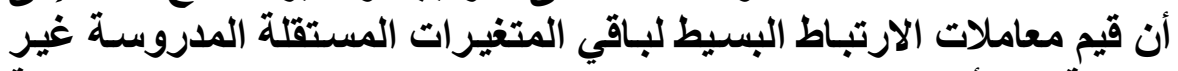

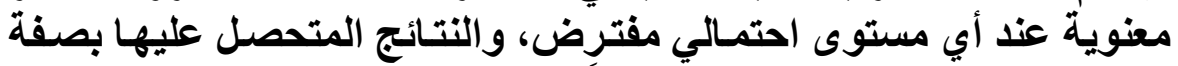

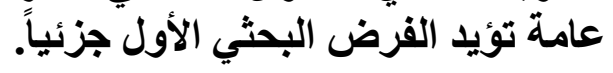

جدول (2): قيم معامل الارتباط البسيط بين المتغيرات المستقلة والمتغير

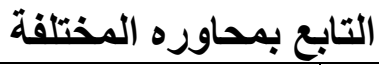

\begin{tabular}{|c|c|c|c|c|c|}
\hline \multicolumn{4}{|c|}{ قيم معامل الارتباط البسيط } & \multirow[t]{2}{*}{ المتغير ات المستقلة } & \multirow[t]{2}{*}{ r } \\
\hline الاستتفادة & الثالث & الثخاني & الأولور & & \\
\hline $0.118-$ & 0.055- & $* 0.147-$ & $0.056-$ & الفرقة الدراسية & 1 \\
\hline$* * 0.330$ & 0.113 & $* * 0.464$ & $* 0.156$ & الاخل الأسرى الشهري & 2 \\
\hline$* * 0.194$ & 0.050 & $* * 0.333$ & 0.041 & مدى كفاية الدخل & 3 \\
\hline 0.055 & 0.100 & 0.083 & 0.111- & عدد غرف المسكن & 4 \\
\hline$* * 0.222$ & 0.017 & $* * 0.351$ & $* 0.148$ & الحالة التعليمية للأب & 5 \\
\hline$* * 0.235$ & 0.137 & $* * 0.204$ & $* 0.181$ & الحالة العملية للأب & 6 \\
\hline 0.112 & 0.061- & $* * 0.220$ & 0.133 & الحالة العملية للام & 7 \\
\hline 0.132 & 0.058 & 0.085 & $* 0.169$ & 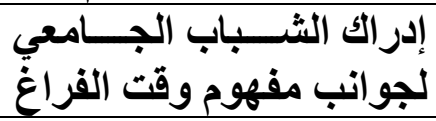 & 8 \\
\hline 0.080- & $0.003-$ & 0.036- & *0.172- & مدى وجود وقت فراغ لاى الشباب الجيعي & 9 \\
\hline$* 0.143$ & 0.077 & $* 0.159$ & 0.075 & 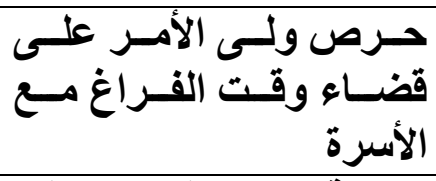 & 10 \\
\hline$* * 0.332$ & $* * 0.385$ & 0.057 & $* * 0.245$ & خطة تنظيم وقت الفراغ & 11 \\
\hline$* * 0.242$ & $* * 0.184$ & $* * 0.206$ & 0.126 & 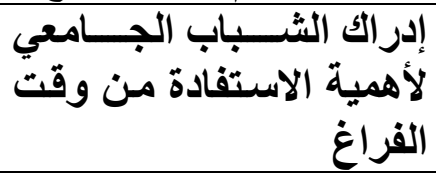 & 12 \\
\hline 0.105 & 0.067 & 0.002 & $* * 0.184$ & 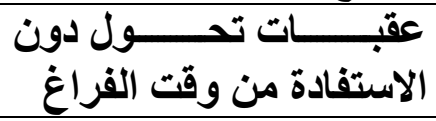 & 13 \\
\hline
\end{tabular}




\begin{tabular}{|c|c|c|c|c|c|}
\hline 0.111- & 0.033- & 0.118- & 0.109- & 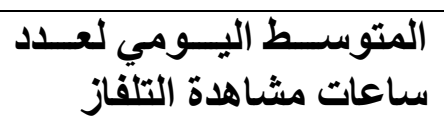 & 14 \\
\hline$* * 0.279$ & 0.065 & $* * 0.444$ & 0.113 & دور العرض التردد الشينهرئي على & 15 \\
\hline$* * 0.443$ & $* * 0.242$ & $* * 0.526$ & $* * 0.187$ & 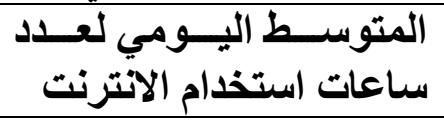 & 16 \\
\hline$* * 0.411$ & $* * 0.237$ & $* * 0.469$ & $* 0.179$ & الانترنــد الصـــــاقات علـــى & 17 \\
\hline
\end{tabular}

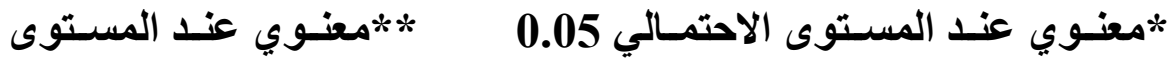
الاحتمالي 0.01

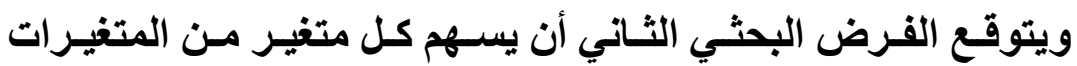

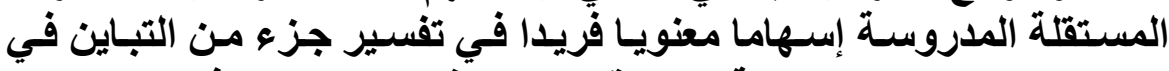

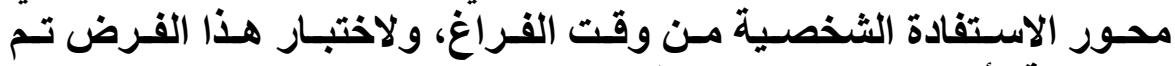

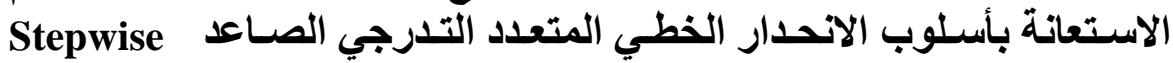
Multiple Regression (Forward Solution) الاستفادة الشخصية من وقت الفراغ، والتعرف معن على الأهمية النسبية لكل

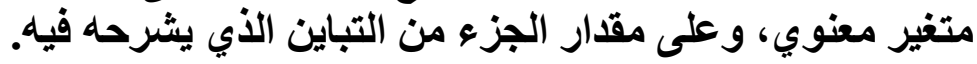

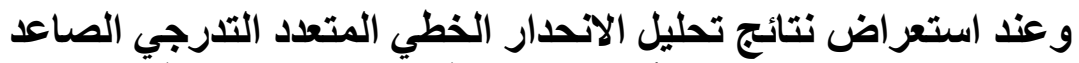

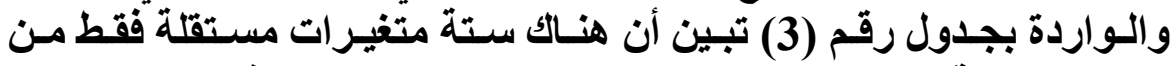

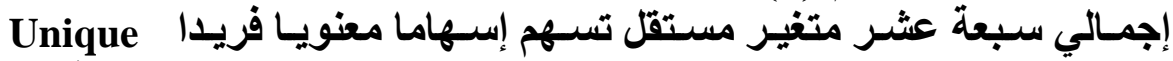

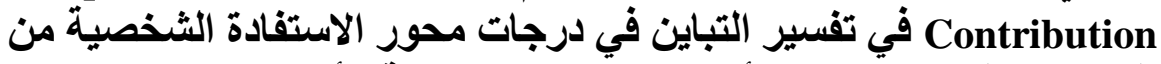

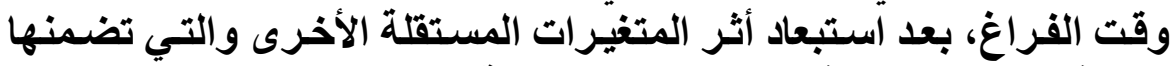

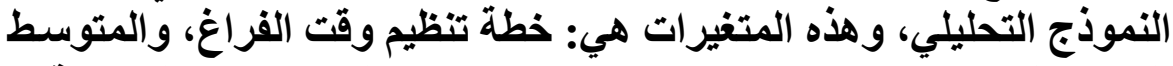

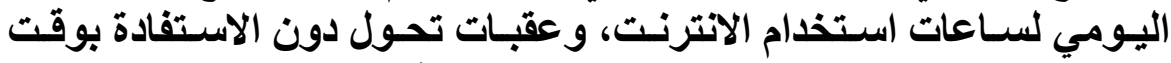

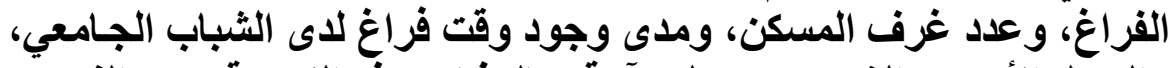

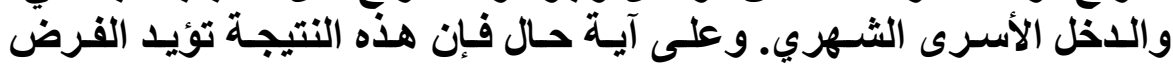
البحثي الثاني جزئيا.

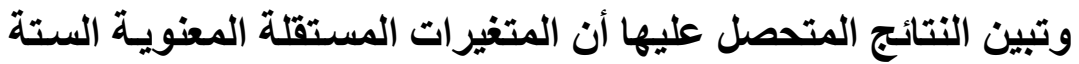

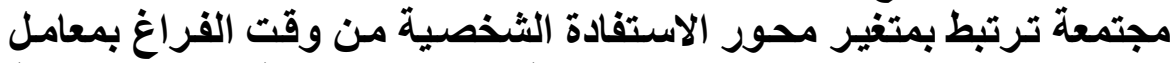

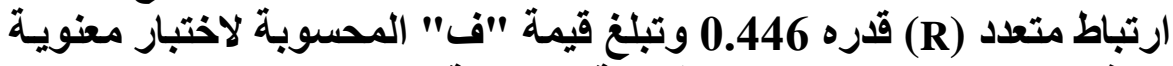

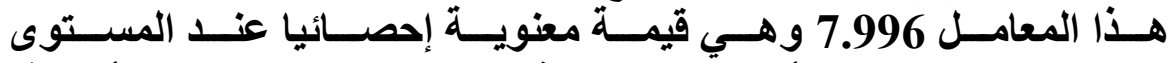

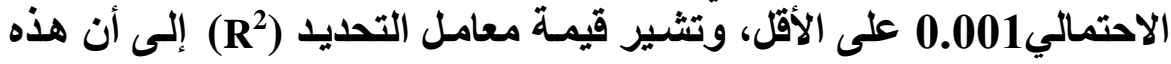


المتغيرات المستقلة الست تفسر نحو 19.9\% من التباين في درجات محور

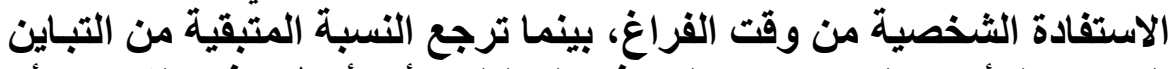
إلى عوامل أخرى لم يتضمنها النموذج التحليلي، أو لأخطاء في القياس، أو الو لغيرها،

وغند الوقوف على نسبة إسـهام كل متغير من المتغيرات المستقلة

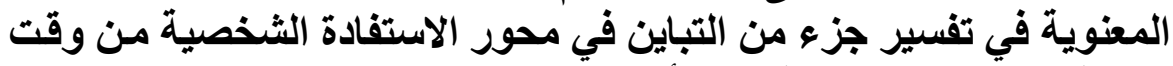

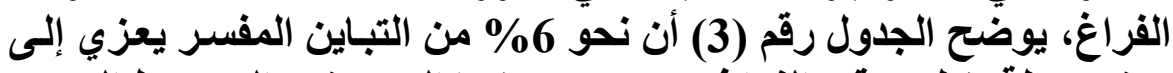

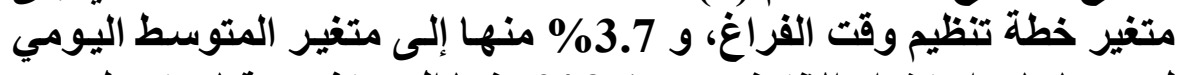

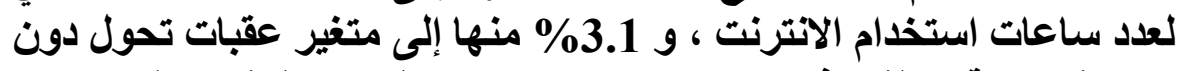

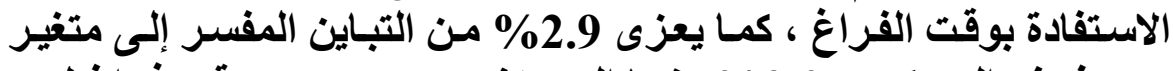

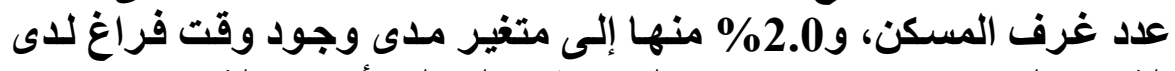

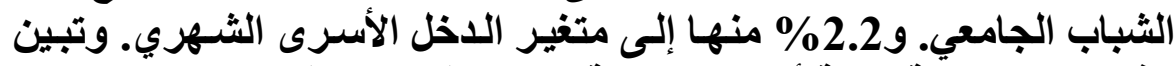

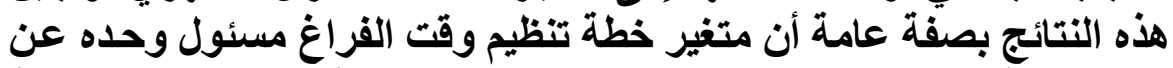

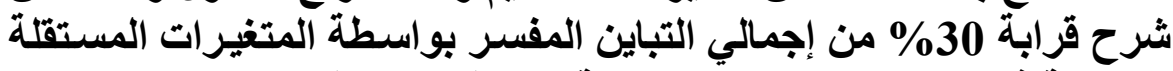
المغنوية في محور الاستفادة ألثخصية من وقت الفراين المفر بواغ. 
جدول (3) : نتائج تحليل الانحدار الخطى المتعدد التّرجي الصاعد بين

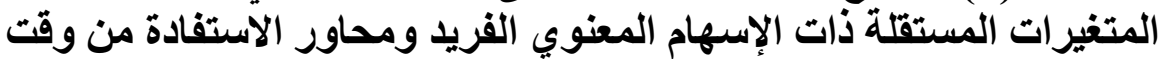
الفراغ والاستفادة الكئية الفيلية 
المصدر : جمعت وحسبت من بيانات الاراسة

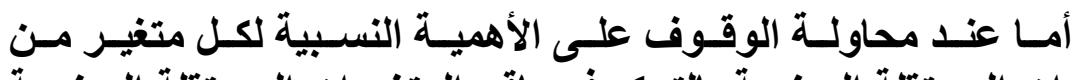

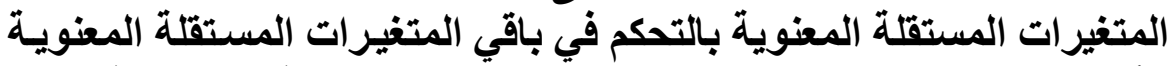

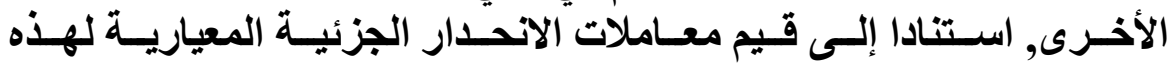

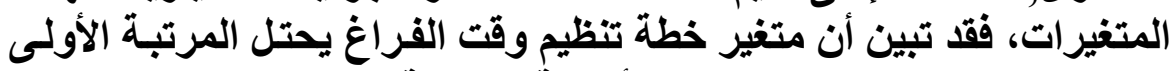

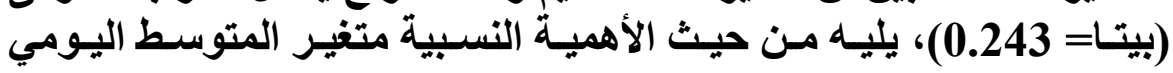

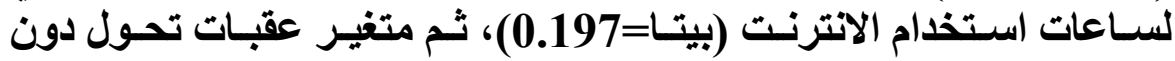
الاستفادة بوقت الفراغ (بيتا=177)

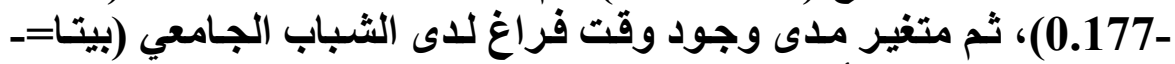

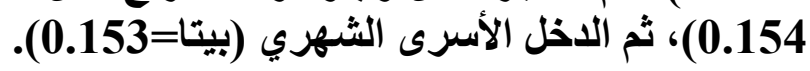

2-العلاقات الارتباطية ومحددات الاستفادة بوقت الفراغ من خلال 


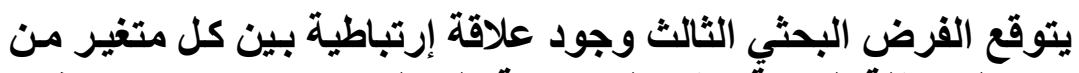

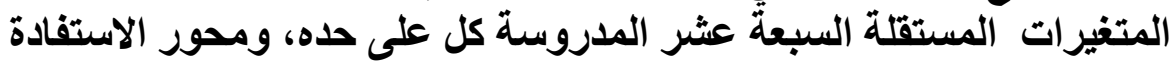

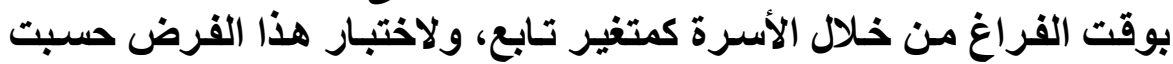

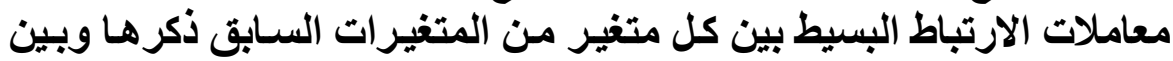

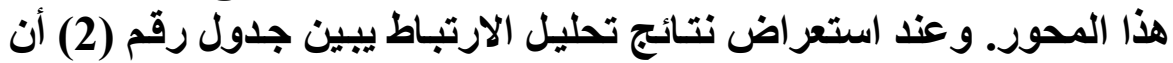

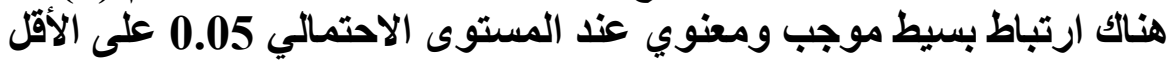

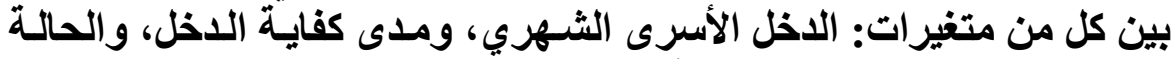

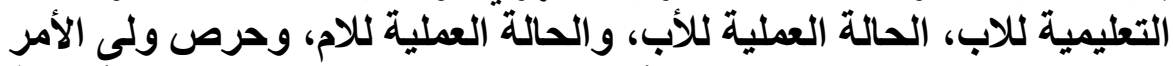

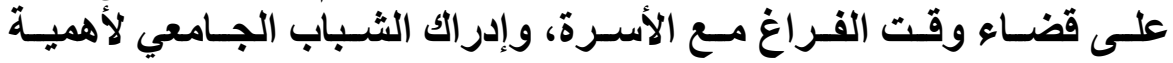

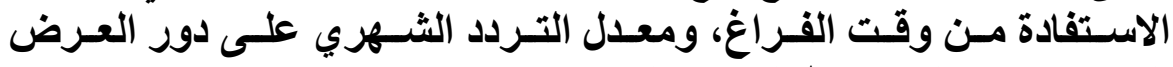

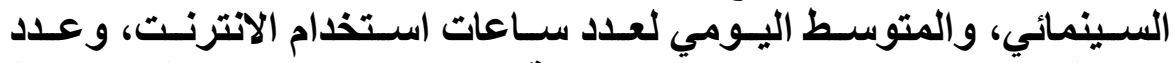

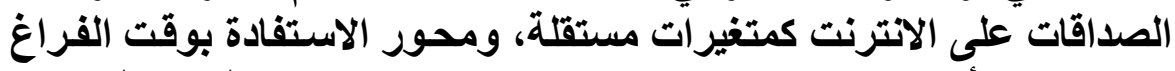

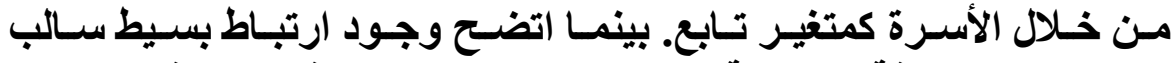

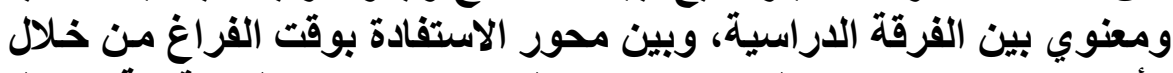

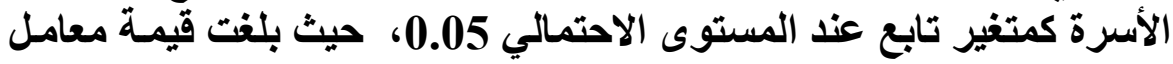

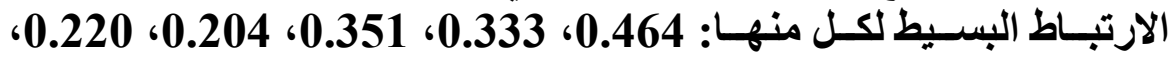

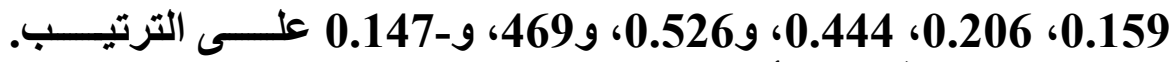
وتثير النتائج كذلك إلى أن قيم معاملات الارتباط البسيط لباقي المتغيرات

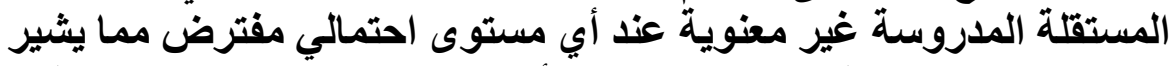

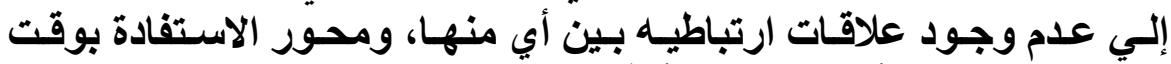

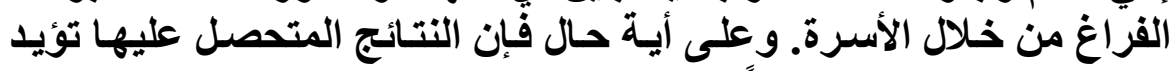
الفرض البحثي الثالث جزئياً.

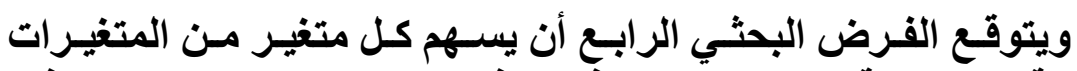

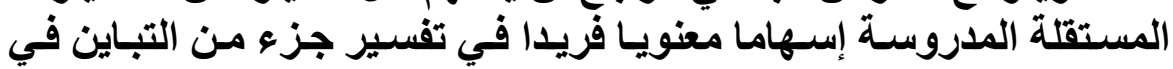

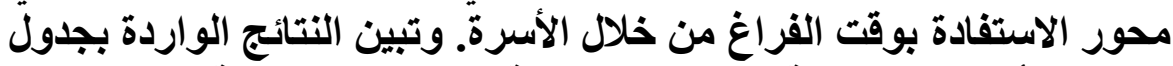

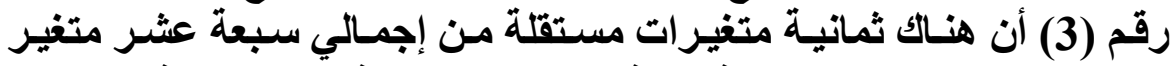

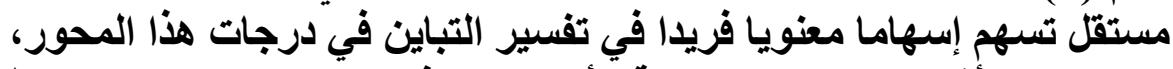

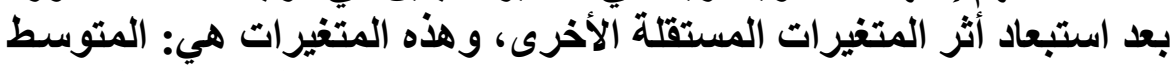

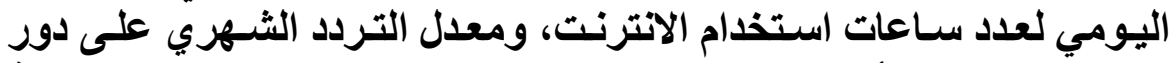

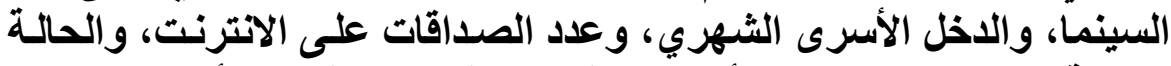

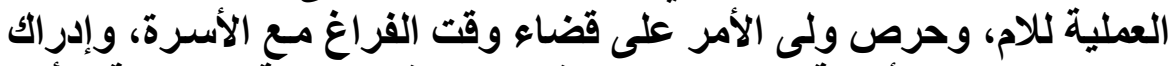

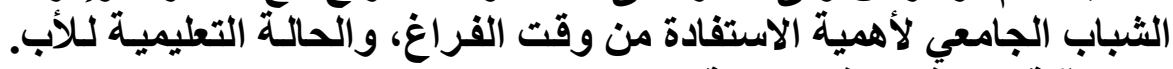

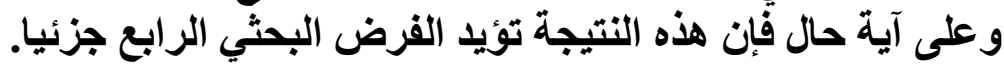




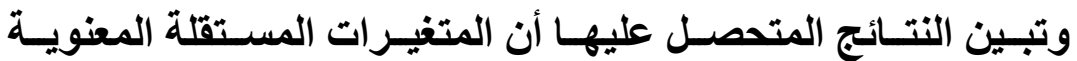

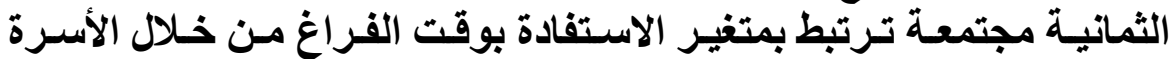

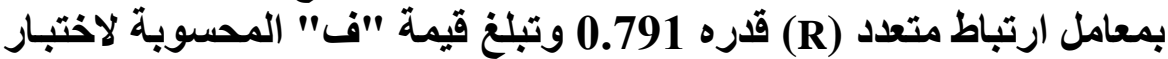

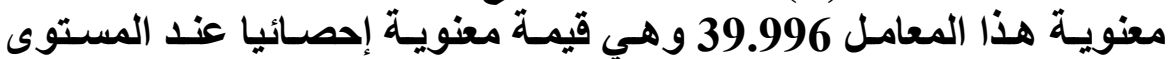

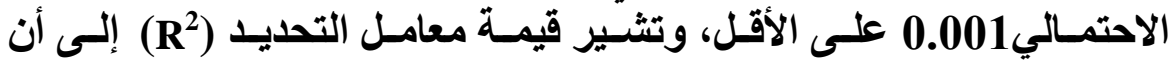
المتغيرات المستقلة الثماتية تفسر نحو 62.6\% من التباين في درجـات هذا المحور.

وعند الوقوف على نسبة إسـهام كل متغير من المتغيرات المستقلة

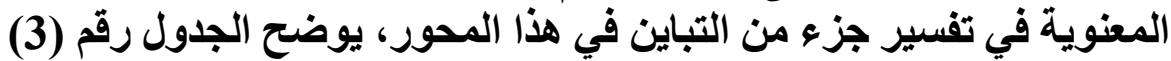

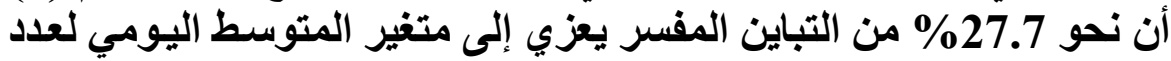

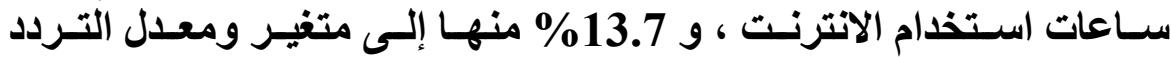

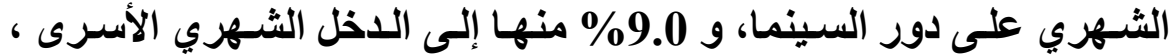

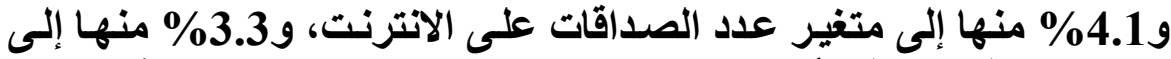

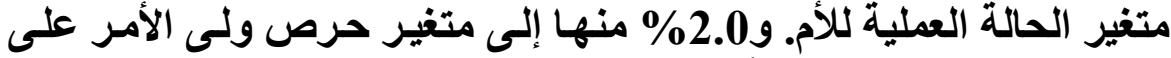

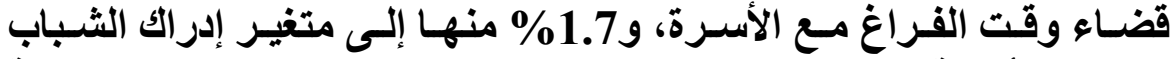

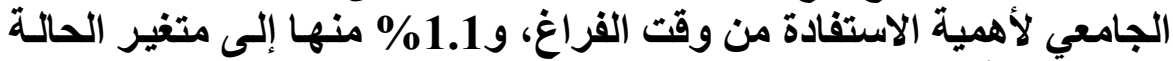

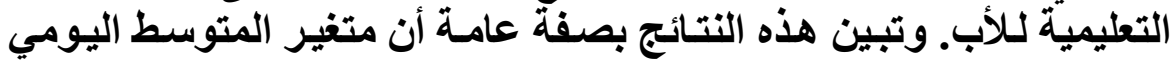

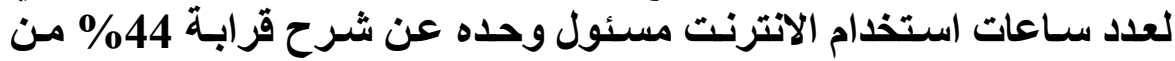

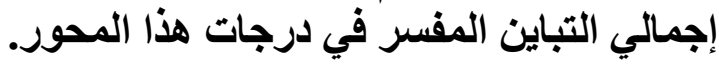

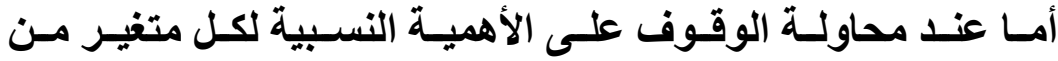

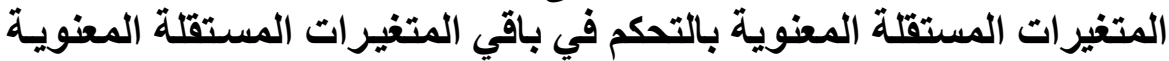

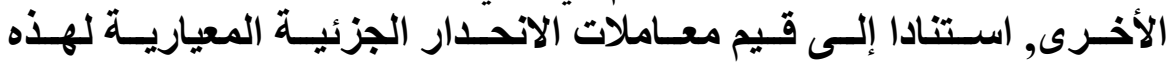

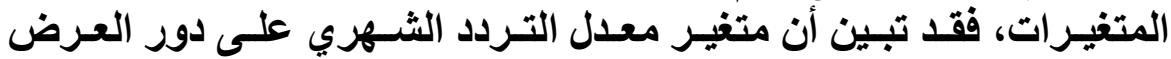

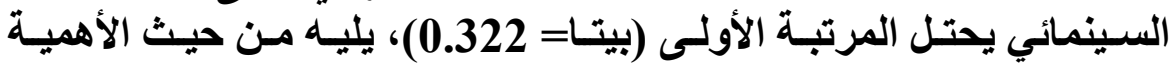

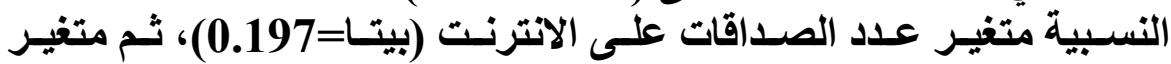

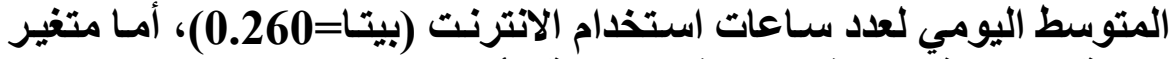

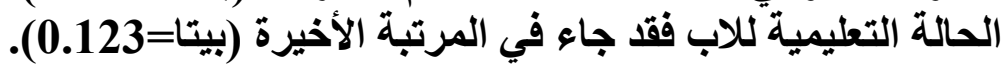

3-العلاقات الارتباطية ومحددات الاستفادة بوقت الفراغ من خلال

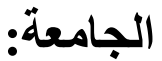

يتوقع الفرض البحثي الخـامس وجود علاقة إرتباطية بين كل متغيز

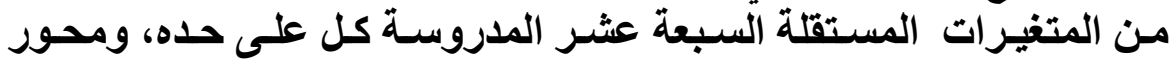

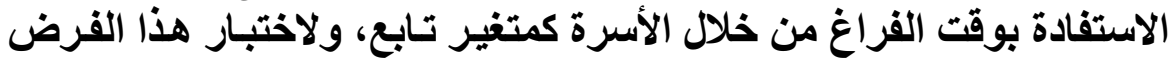


حسبت معاملات الارتباط البسيط بين كل متغير من المتغيرات السـابق ذكرهـا

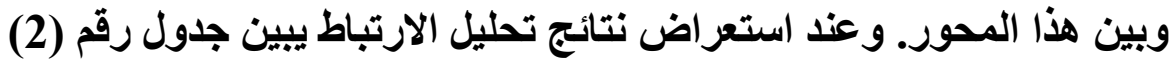

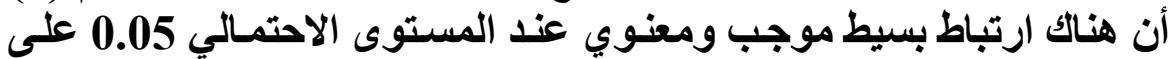

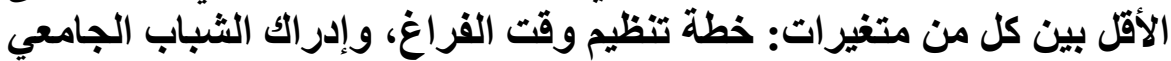

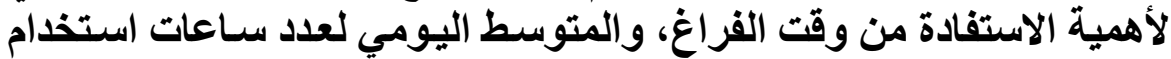

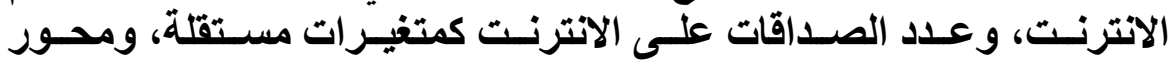

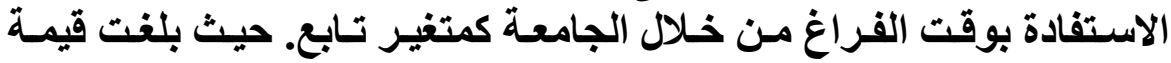

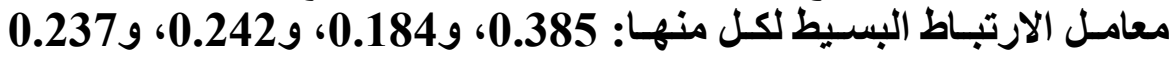

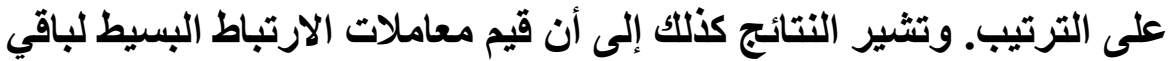

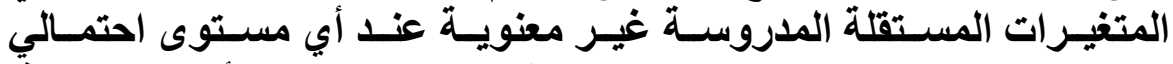

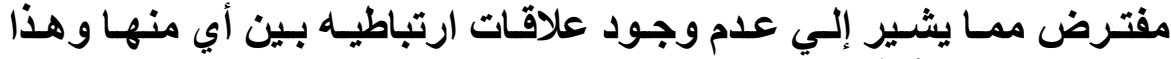

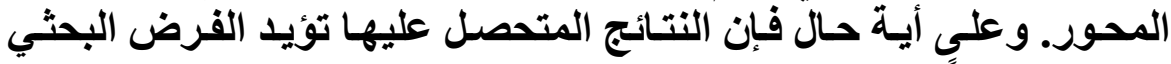
الخامس جزئياً.

ويتوقع الفرض البحثي السـادس أن يسـهم كل متغير من المتغيرات

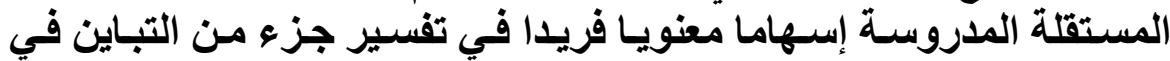

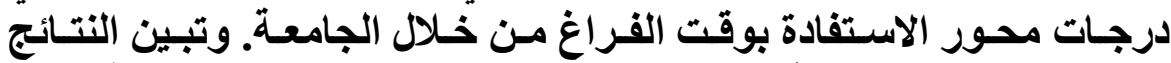

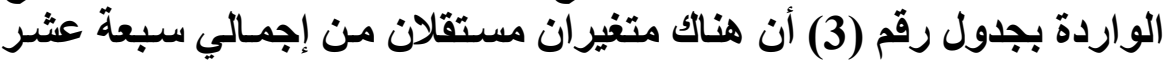

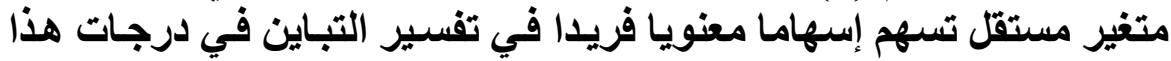

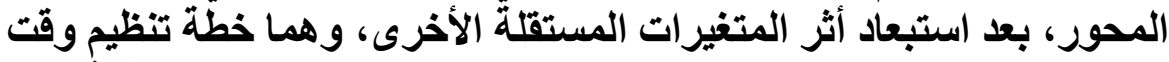

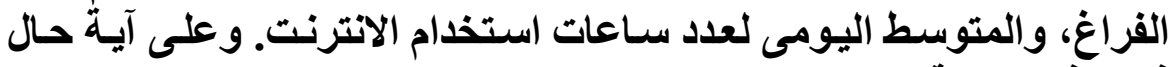

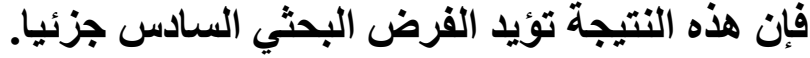

وتبين النتائج المتحصل عليها أن هذين المتغيرين يرتبطان بمتغير

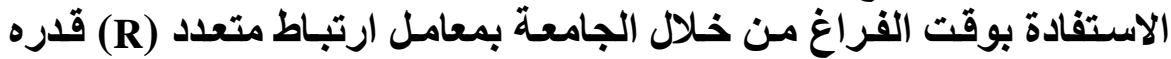

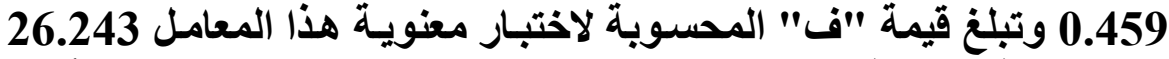

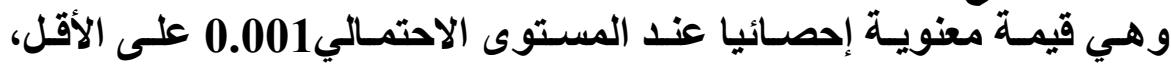

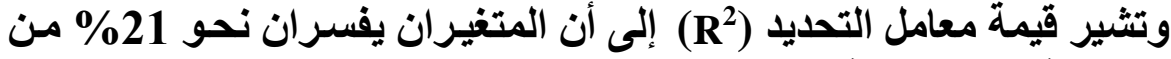
التباين في درجات هذا المحور.

وعند الوقوف على نسبة إسهام كل متغير في تفسير جزء المن من التباين

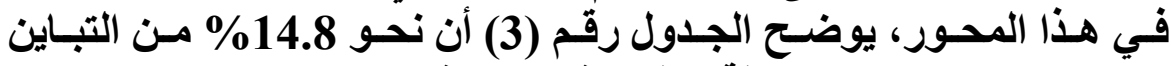

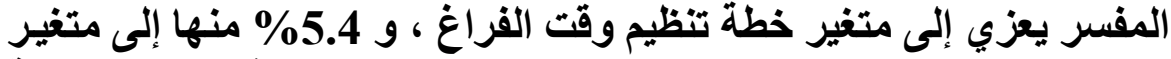

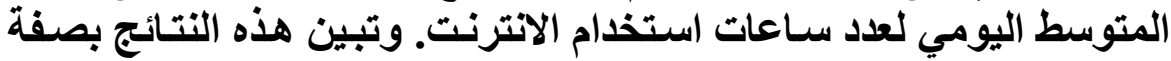

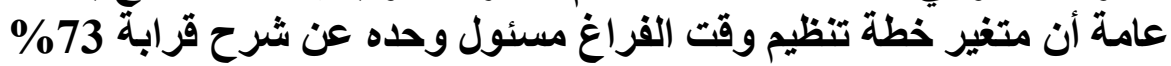

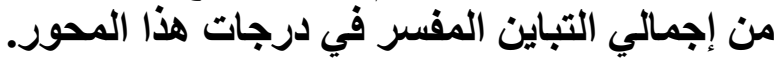




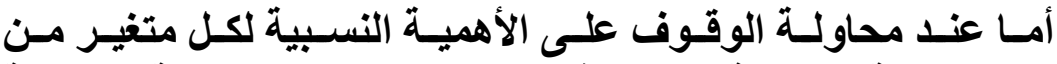

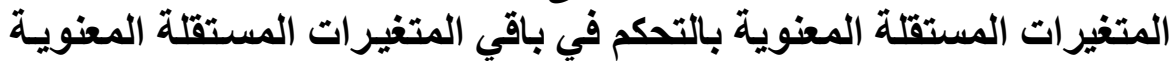

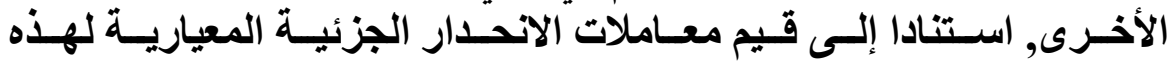

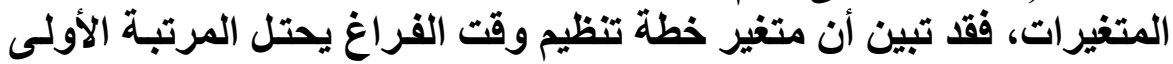

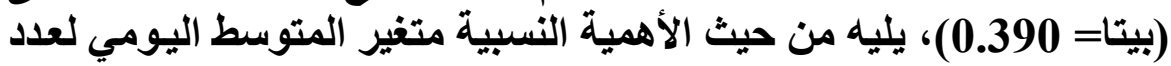

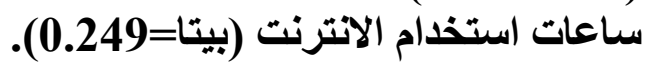

4-العلاقات الارتباطية ومحددات الاستفادة بوقت الفراغ من الن خلاتل

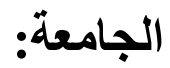

يتوقع الفرض البحثي السابع وجود علاقة إرتباطية بين كل متغير من

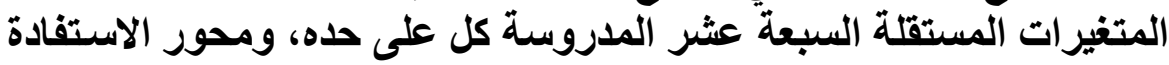

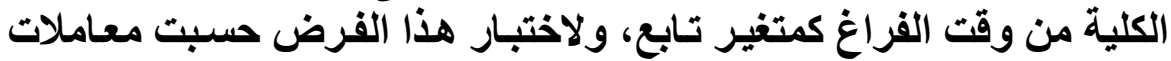

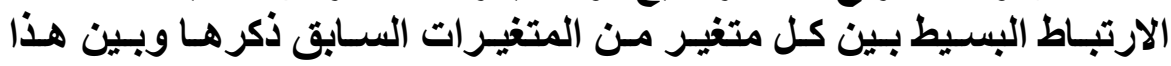

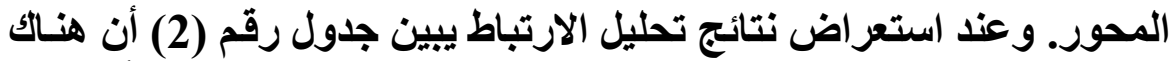

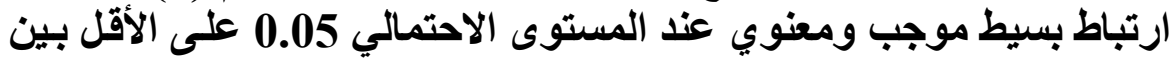

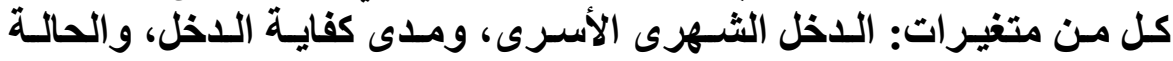

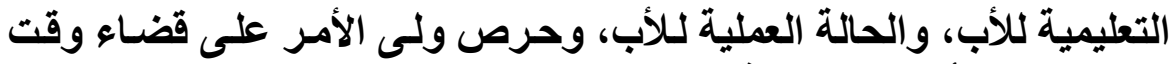

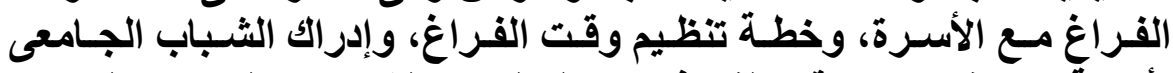

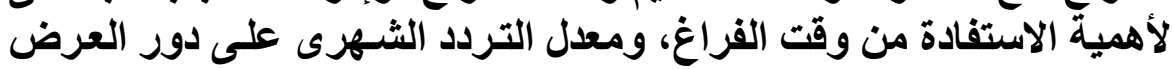

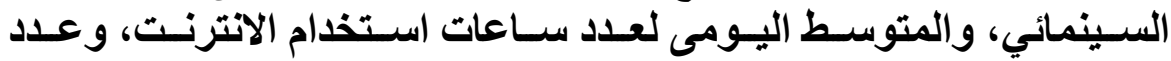

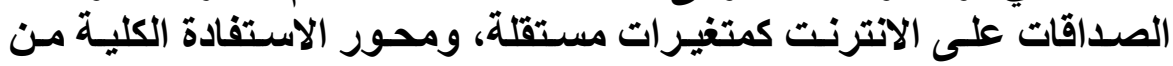

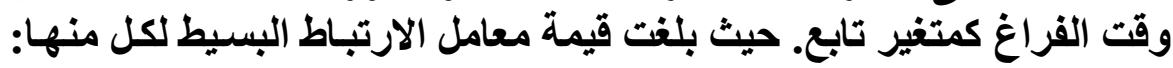

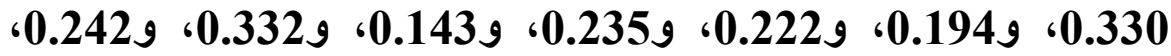
و0.279، و0.443، و0.411 ولى ولى الترتيب. وتثثير النتائج كنلك إلى أن قيم

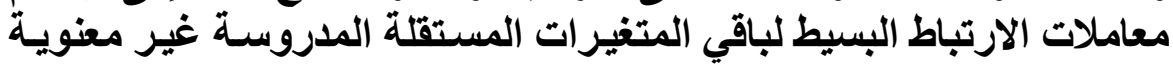

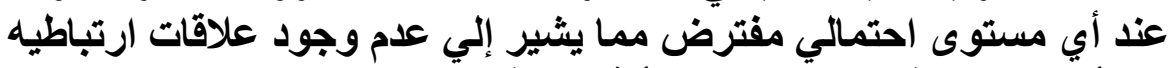

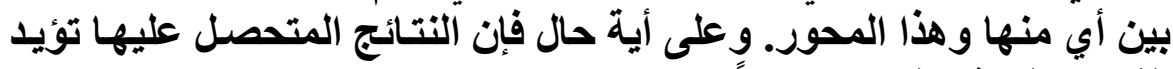
الفرض البحثي السابع جزئياً.

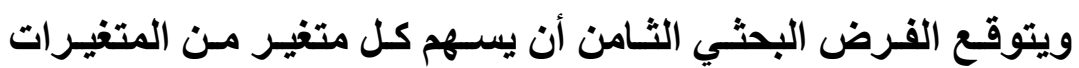

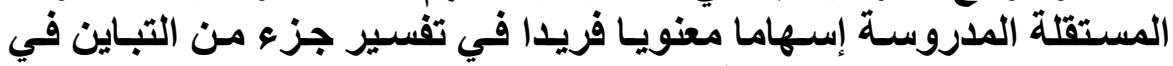

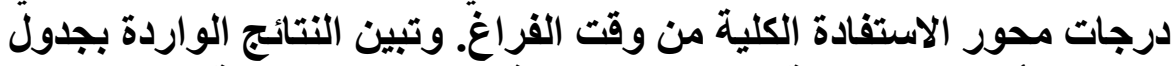

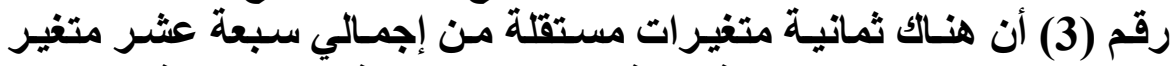
مستقل تسهم إسهاما معنويا فريدا في تفسير التباين في درجات هذان هذا المحور، 
وذلك بعد استبعاد أثر المتغيرات المستقلة الأخرى، وهى: المتوسط اليومي

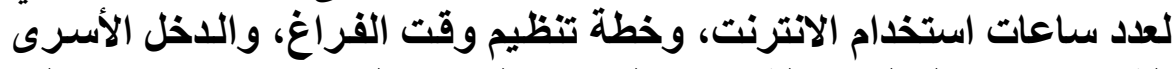

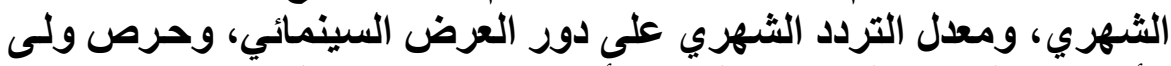

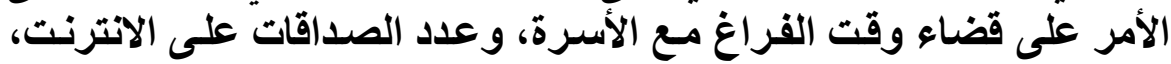

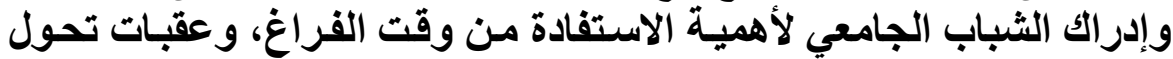

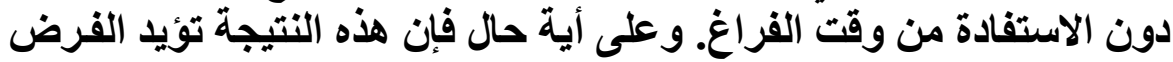

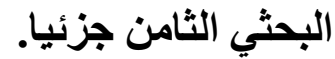

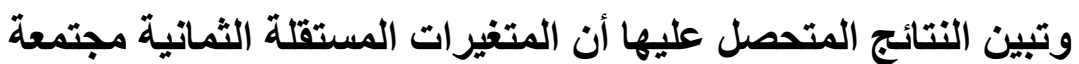

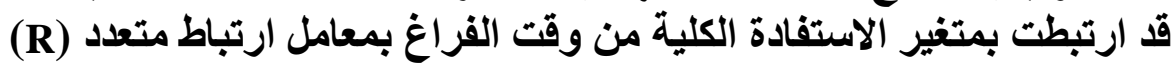

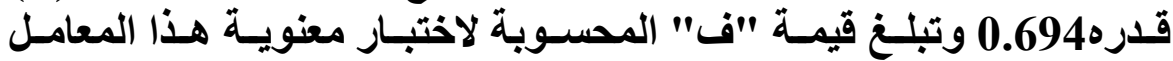

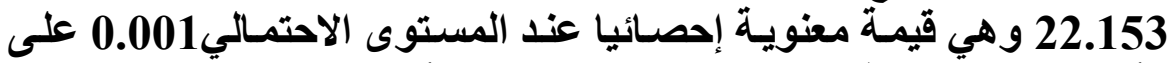

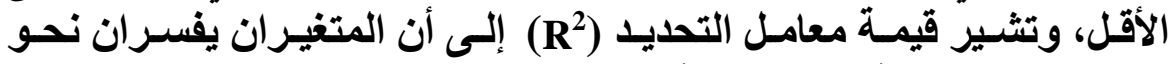
48\% من التباين في درجات هذا المحور.

وعند الوقوف على نسبة إسهام كل متغير في تفسير جزء من من التبائ التباين

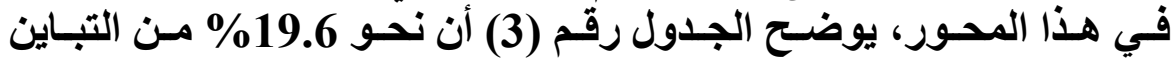

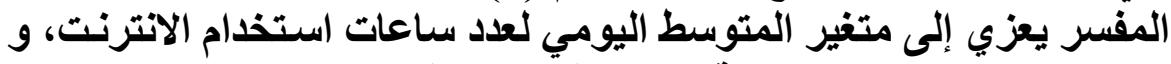

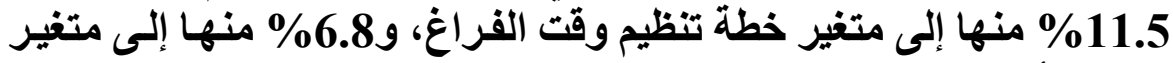

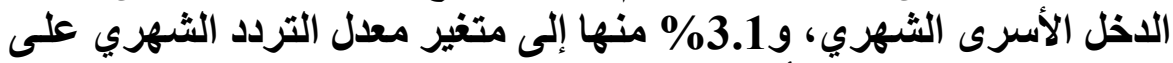

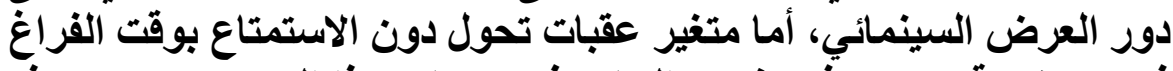

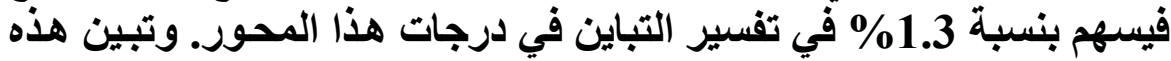

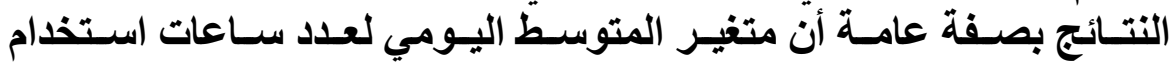
الانترنت مسئول وحده عن شرح قرابة 41\% من إجمالي التباين المفسر في درجات هذا المحور.

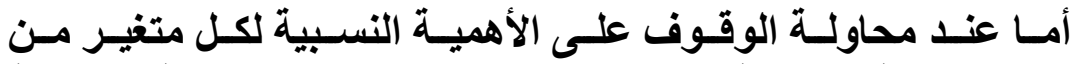

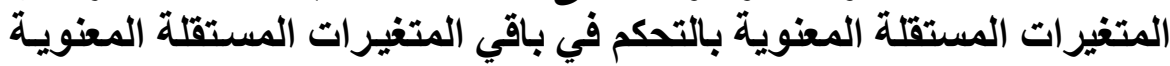

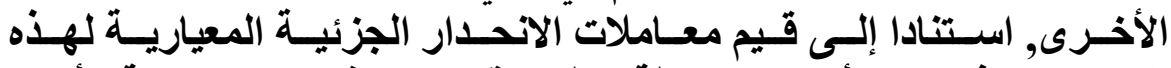

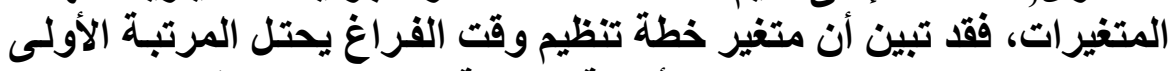

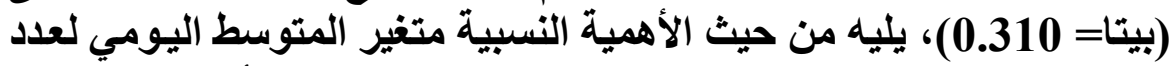

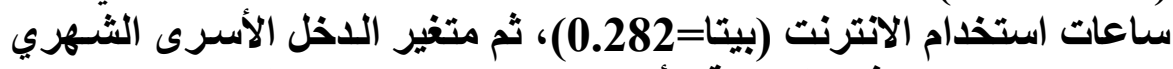
(بيتا= 0.208)، وفى المرتبة الأخيرة متغير عقبات تحول دون الأنت الاستمتاع بوقت الفراغ (بيتا= 0.115). 
ثُالثًاً: الفروق بين طلاب الكليـات العملية وطلاب الكليـات

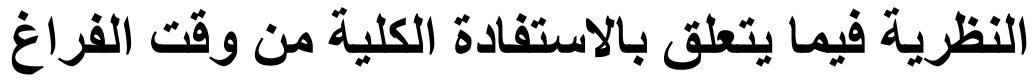

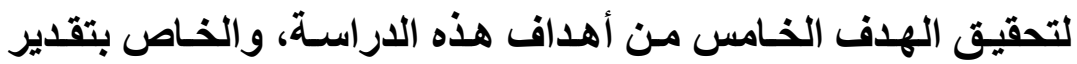

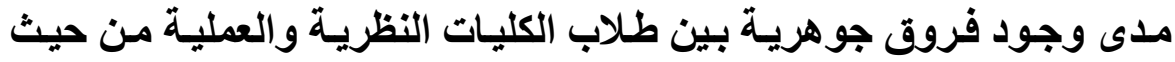

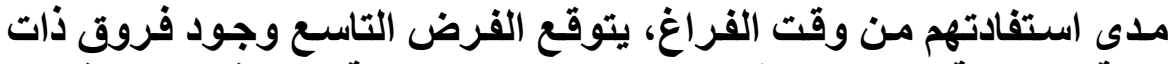

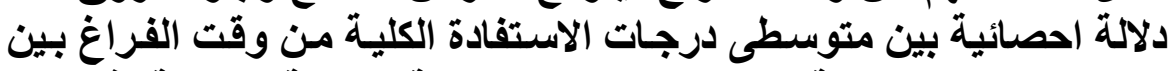

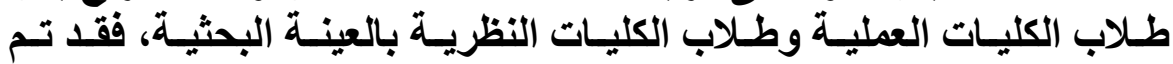

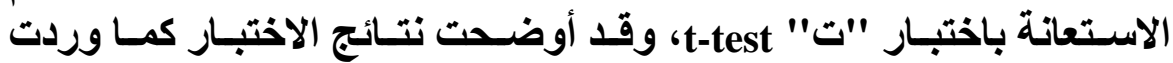

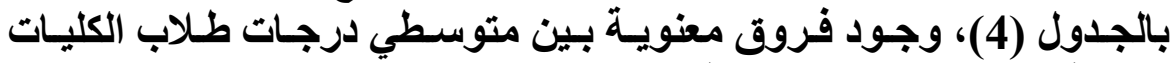

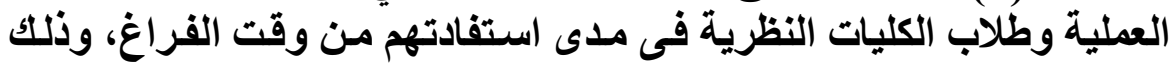

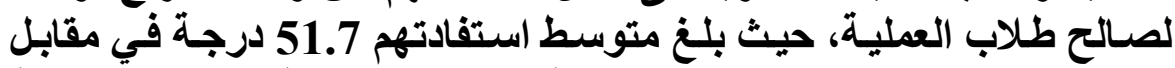

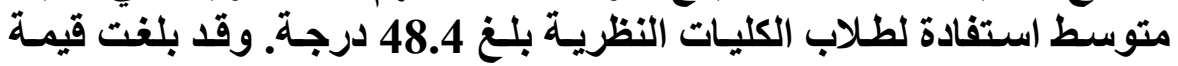

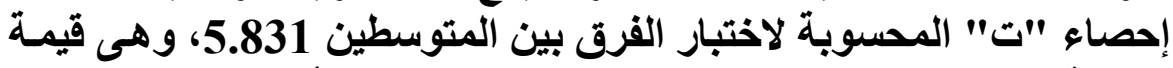
معنوية إحصائيا عن المستوى الاحتمالي 0.001 على الأقل.

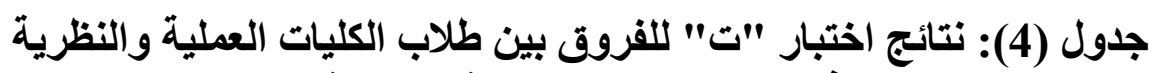

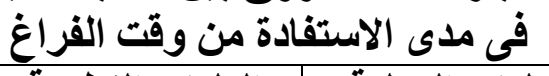

\begin{tabular}{|c|c|c|c|}
\hline \multirow{2}{*}{ "قيمة ومعنوية } & الكليات النظرية & ناب=ات العملية & \multirow[t]{2}{*}{ المتغير التابع } \\
\hline & المتوسط الحسابي & المتوسط الحسابي & \\
\hline$* 5.831$ & 48.4 & 51.7 & من وقتا الإنقاغ الكلية \\
\hline
\end{tabular}

* منوي عند 0.001 على الأقل

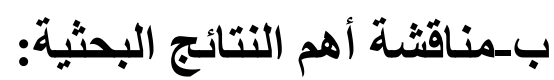

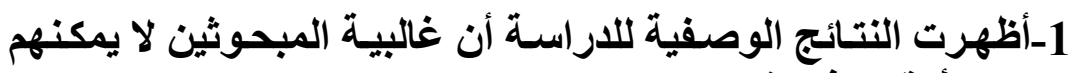

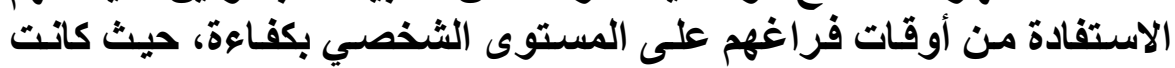

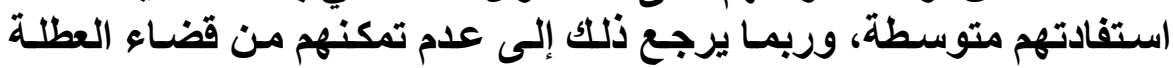

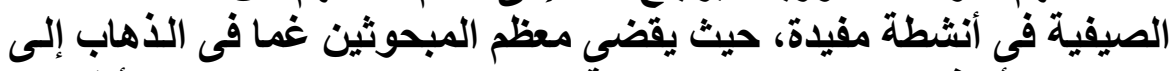

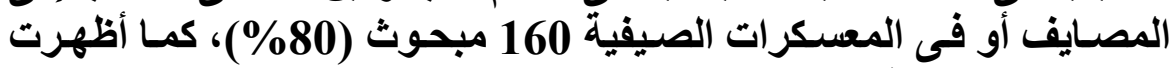

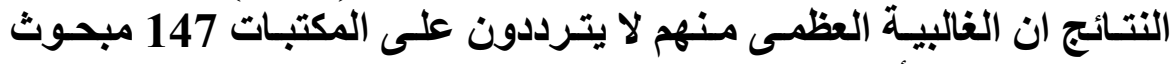

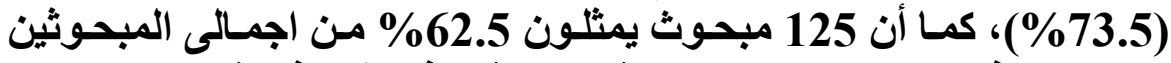
يحرصون فى بعض الاحيان على قضـاء وقت فر اغهم فى قراءة المجلات المبن 
والروايات القصصية والكتب الثقافية على الترتيب من حيث الأولويـة. كذلك

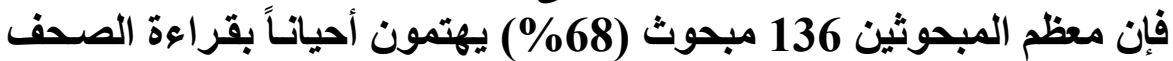

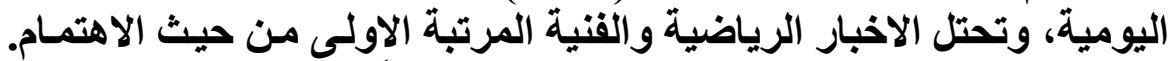

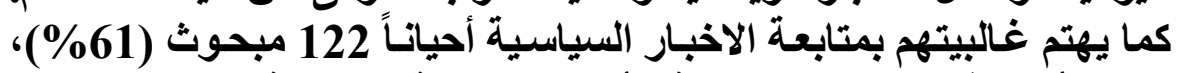
وهو الأمر الذى قد تفرضه طبيعة الأحداث العالمية والمحلية المعاصرة.

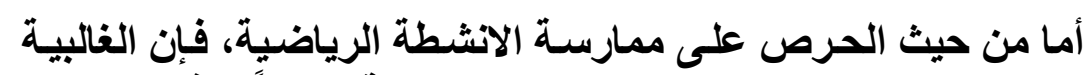

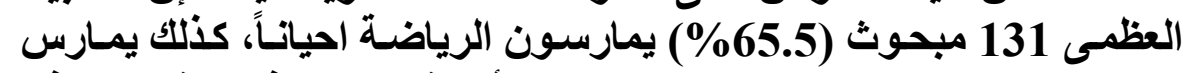

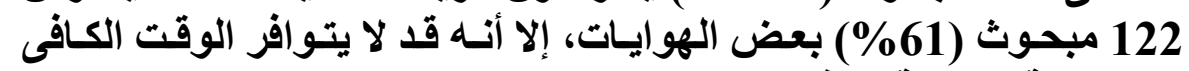

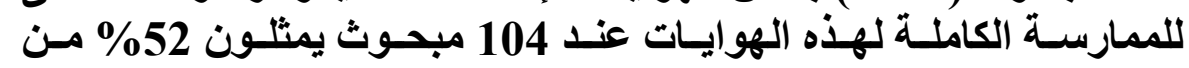
اجمالى مبحوثى العينة.

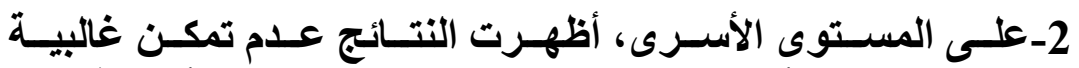

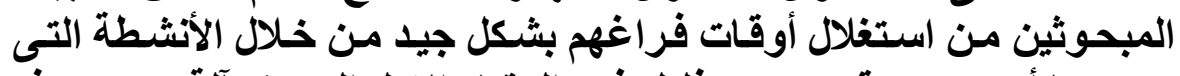

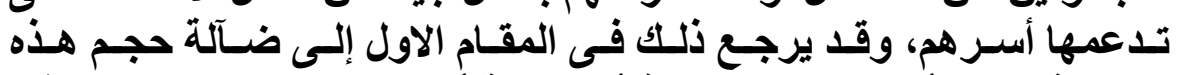

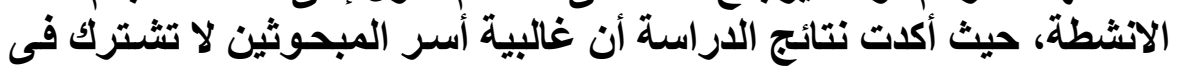

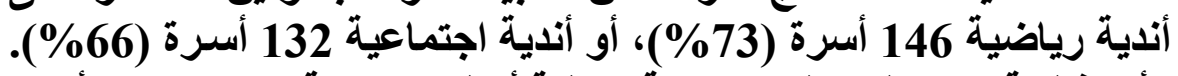

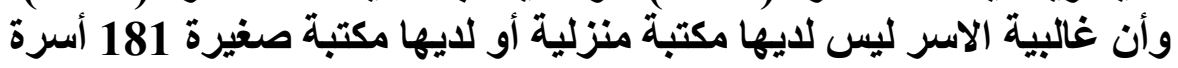

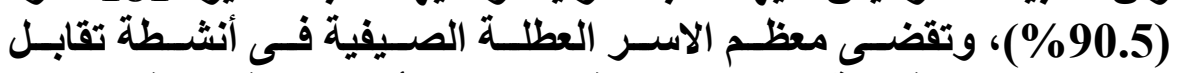

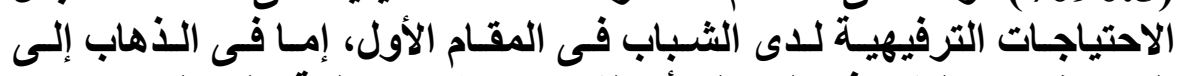

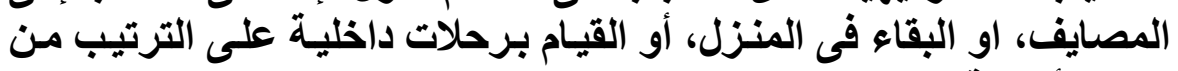

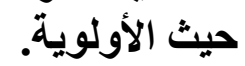

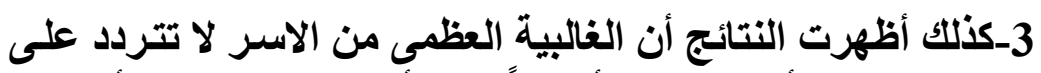

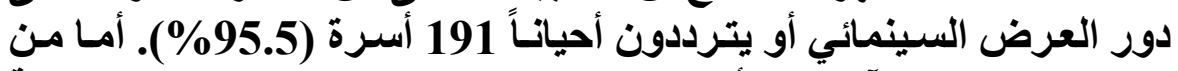

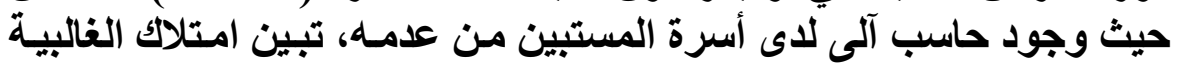

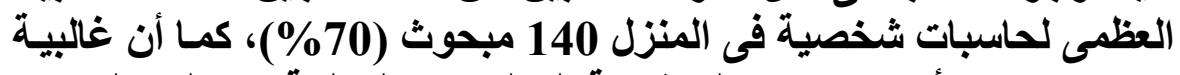

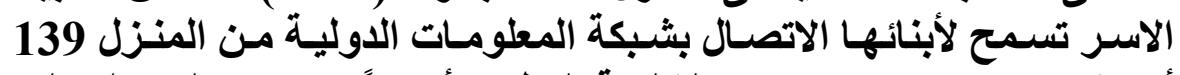

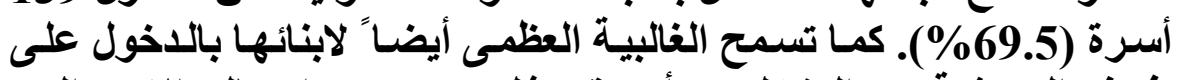

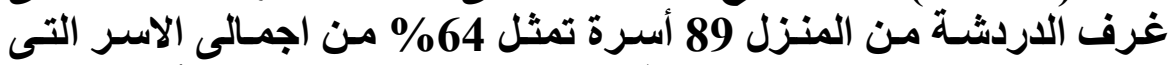

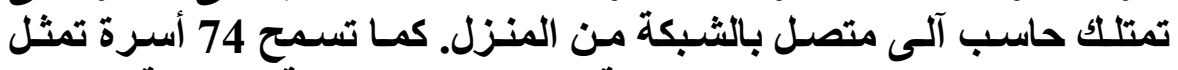

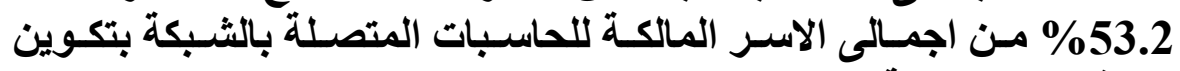
صداقات على شبكة الانترنت.

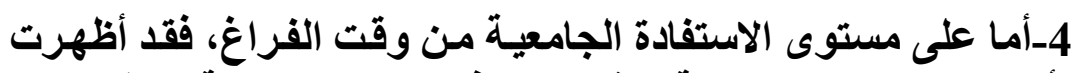
النتائج أن الاستفادة كاتت متدنية، وقد يرجع ذلك إلى ان الغالبية العظمى من 


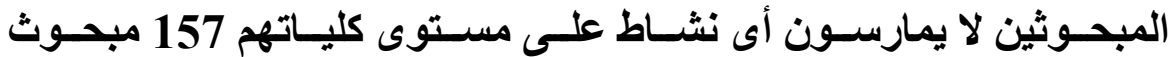

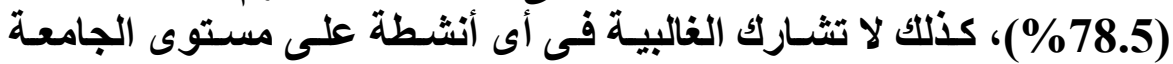

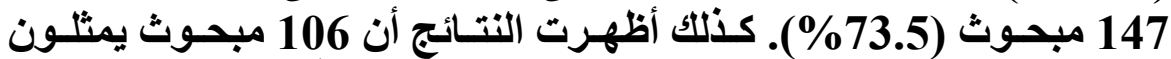

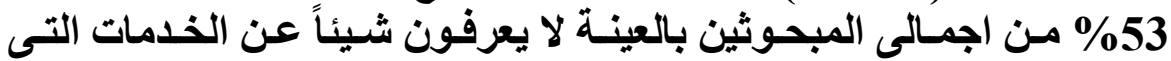

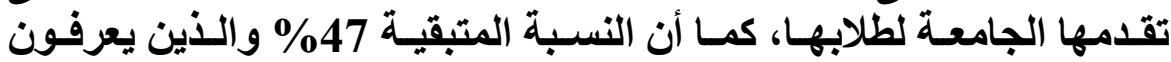

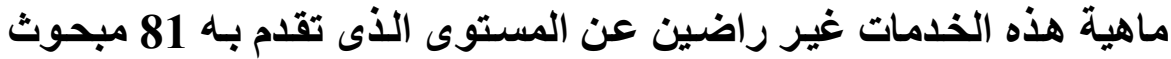
.(\%86.2)

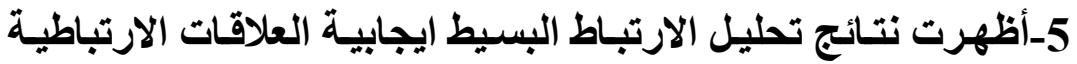

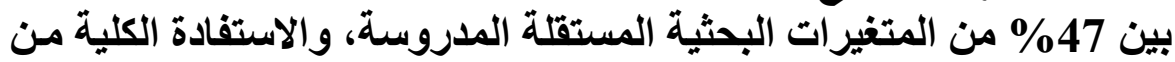

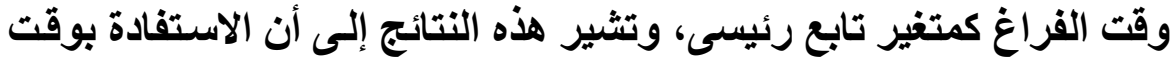

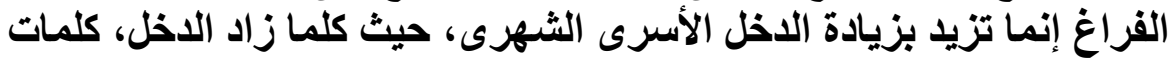

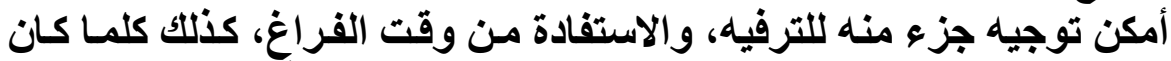

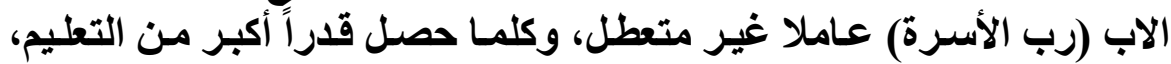

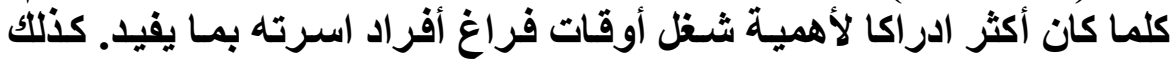

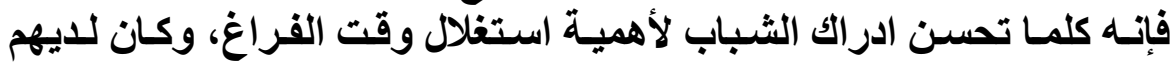
خطة لتنظيم هذا الوقت كلما تمكنوا من تعظيم استفادتهم منهـ.

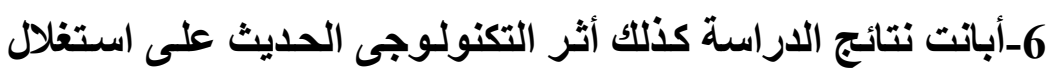

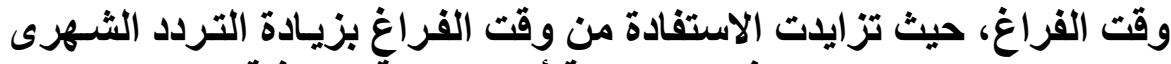

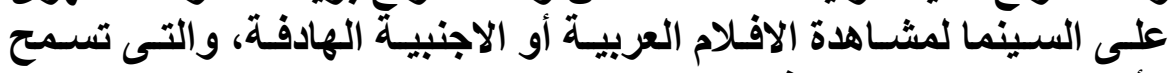

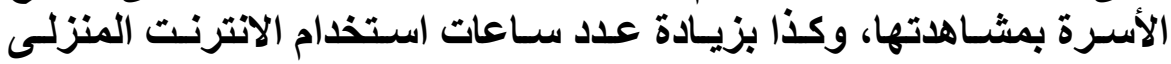
وبتكوين صداقات من خلاله.

7-أكدت نتائج تحليل الانحدار الخطى المتعدد التدرجى الصاعد الاسهام

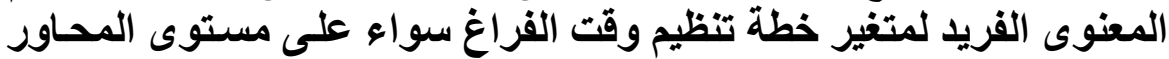

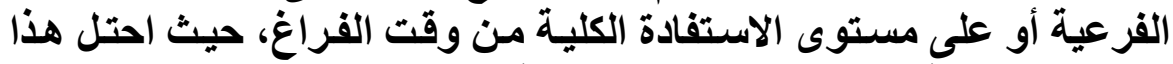

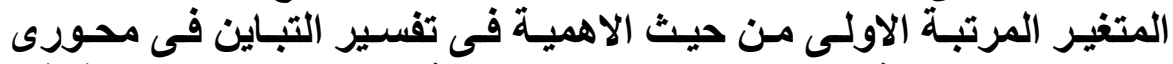

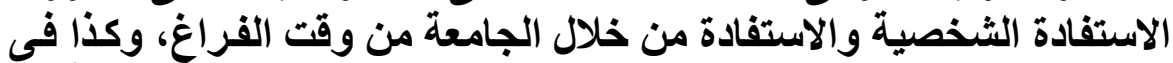

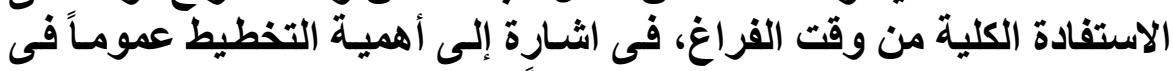

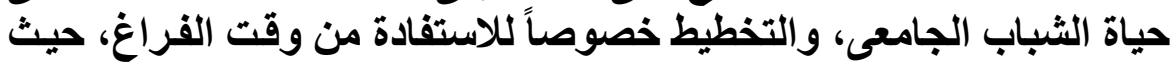

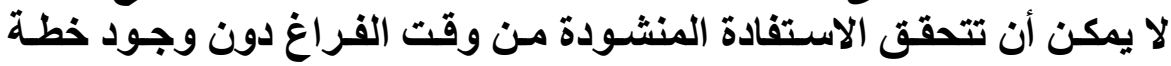

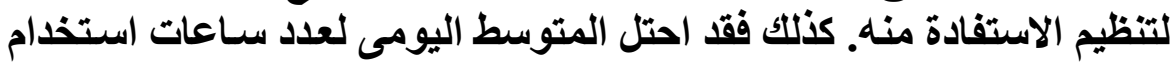

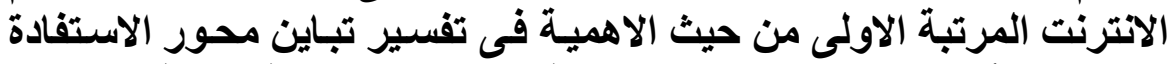

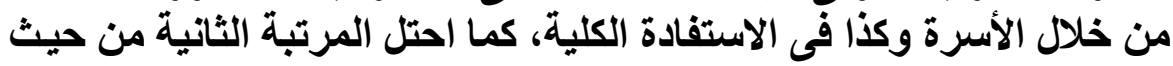

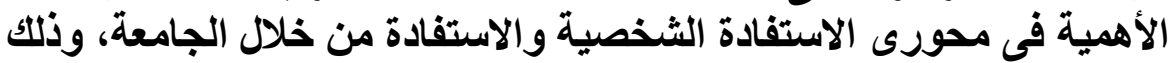




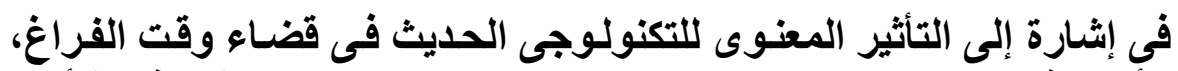

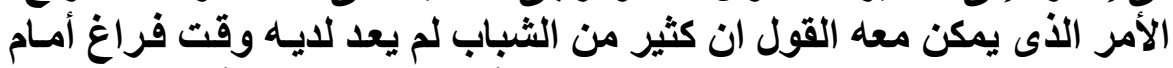

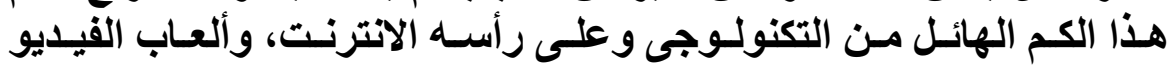

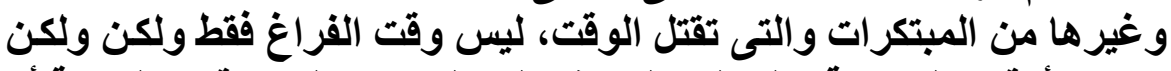

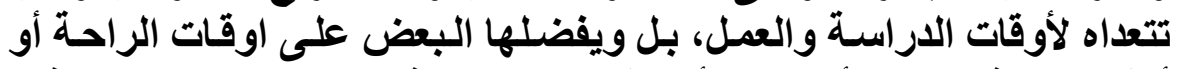

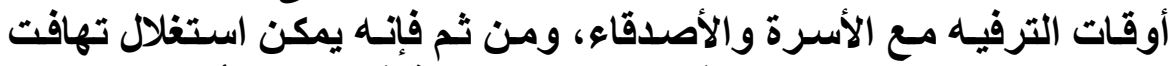

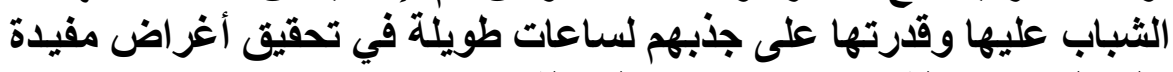

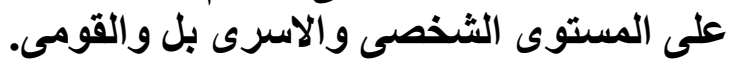

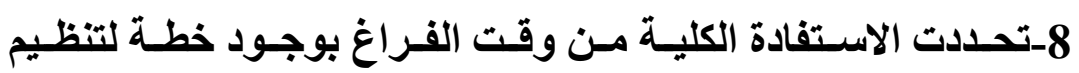

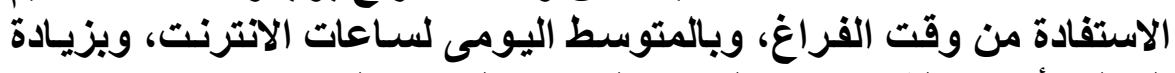

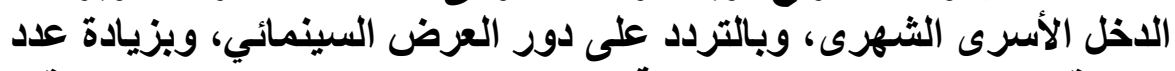

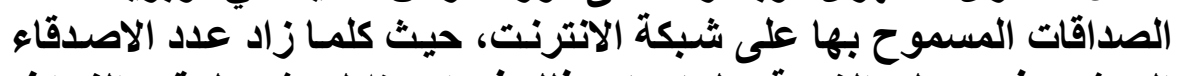

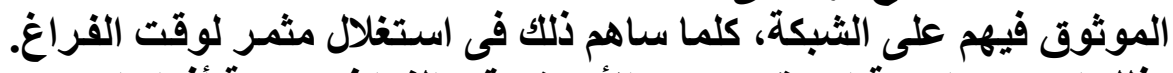

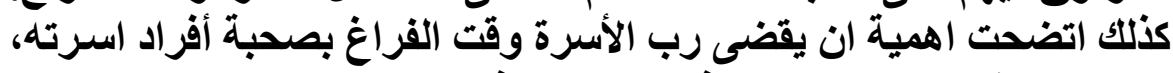

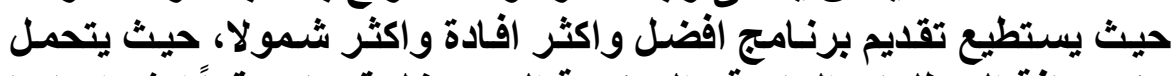

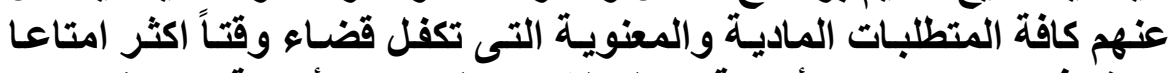

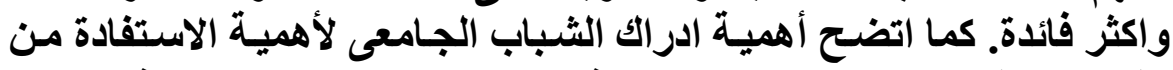

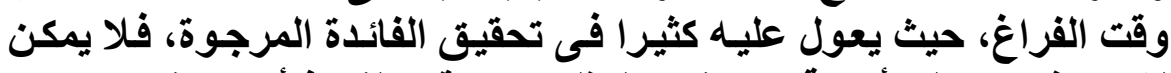

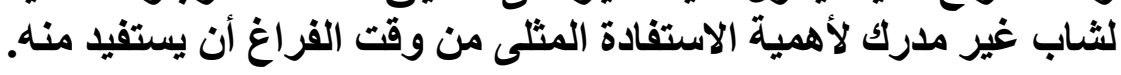

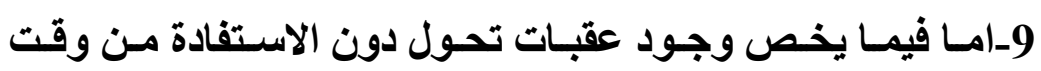

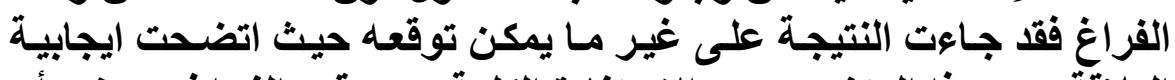

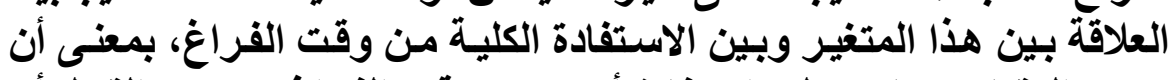

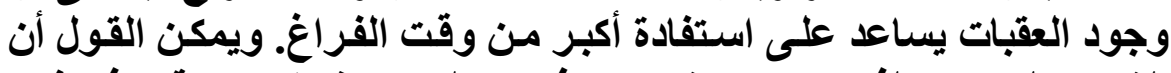

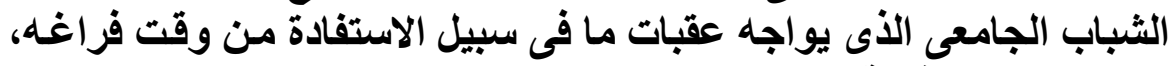

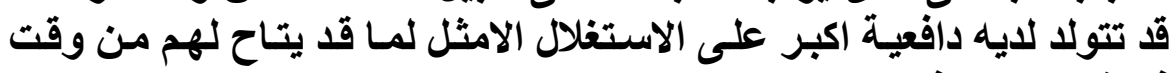

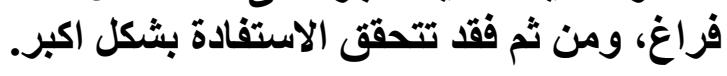

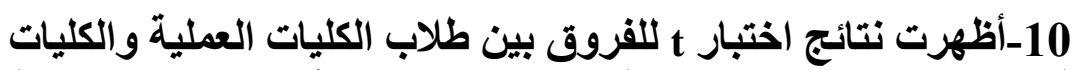

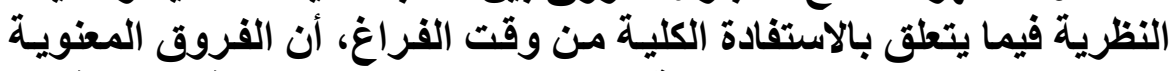

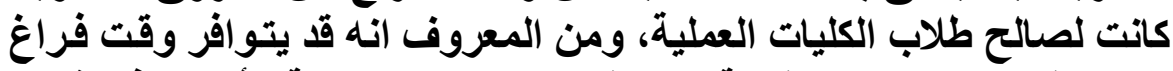

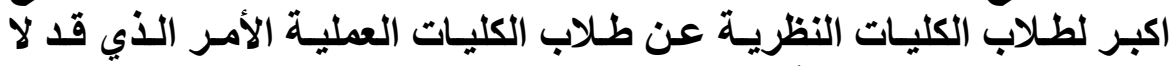

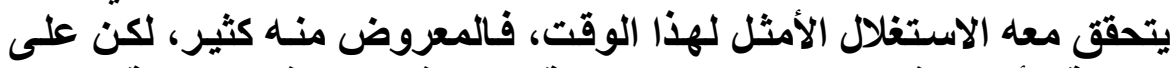

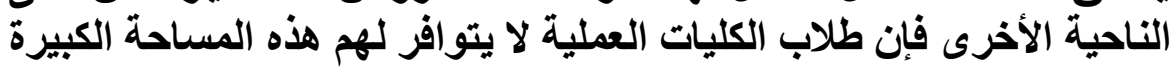

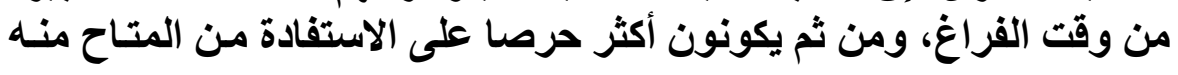


ـ وتؤكد هذه النتيجة ما ذكر آنفا من أن وجود العقبات قد يساعد على حسن استغلال وقت الفراغ والاستفادة منه.

\section{التوصيات والمقترحات}

في إطـار النتـائج الوصـفية والتحليليـة التي أسـفرت عنهـا

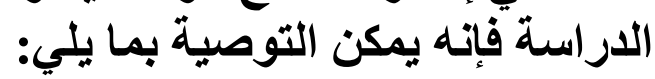

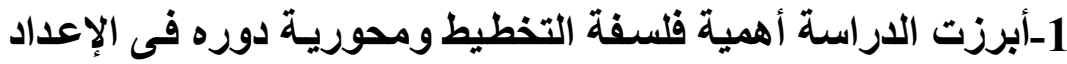

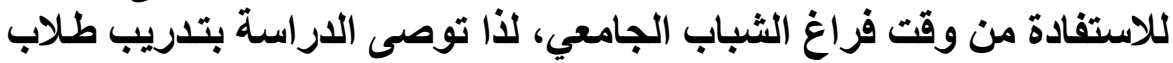

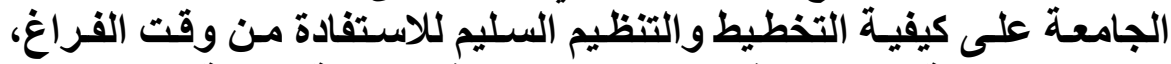

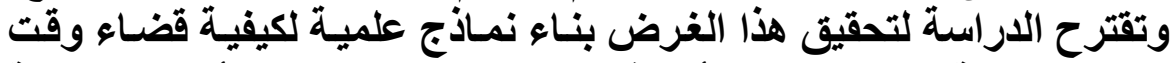

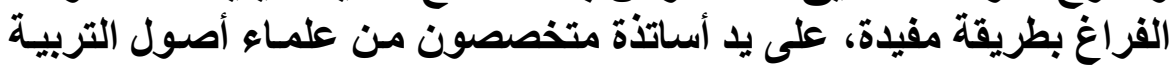

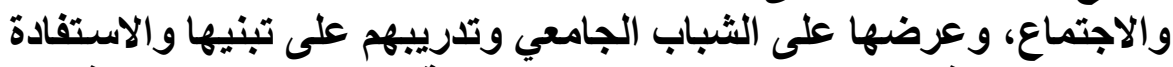

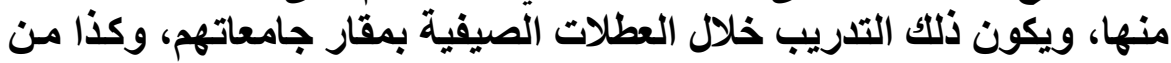

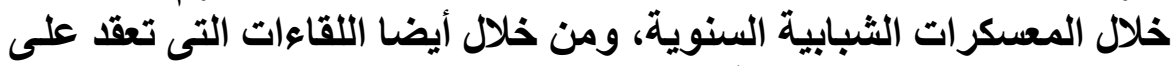

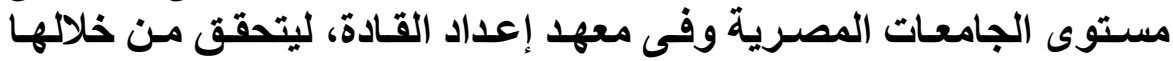
التوجيه الأمثل الذى يحقى الغاية المنشودة.

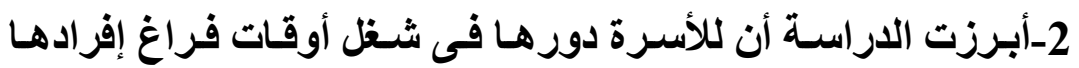

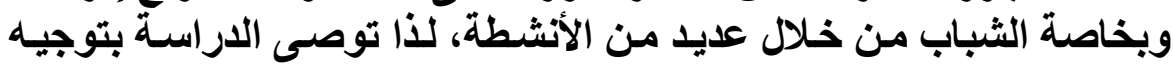

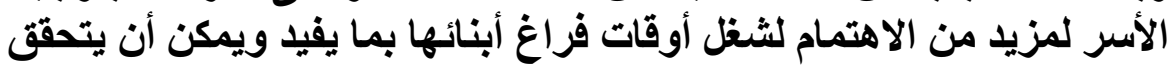

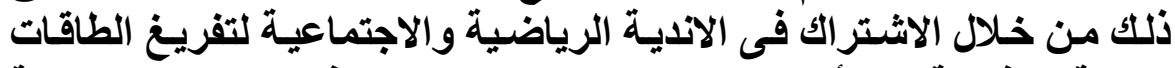

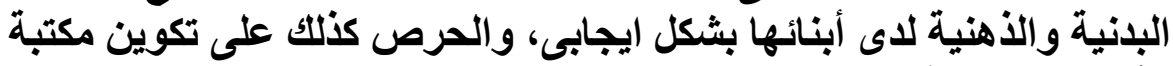

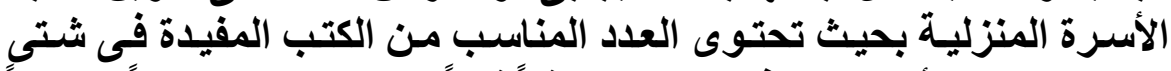

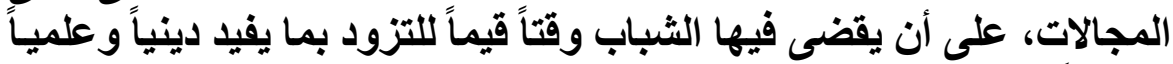

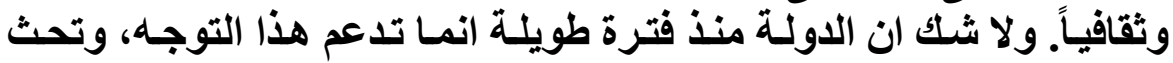

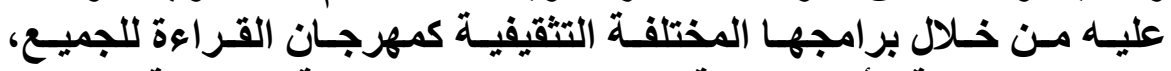
وإصدارات مكتبة الأسرة القيمة ومعارض الكتاب السنوية والدورية. 


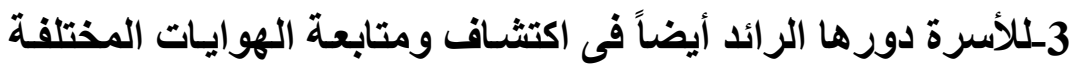

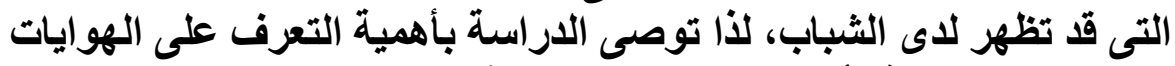

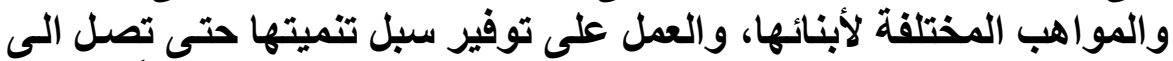

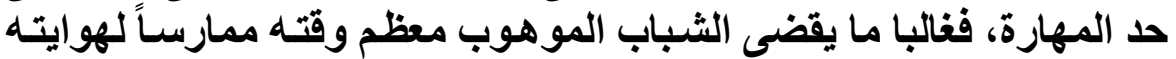

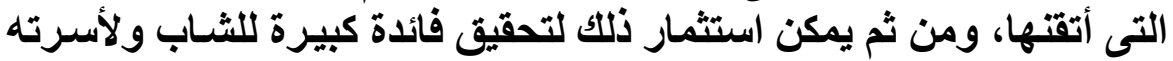

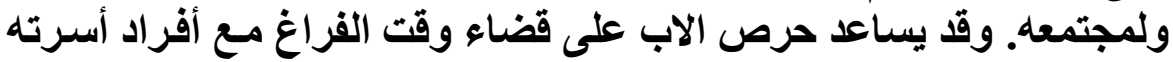

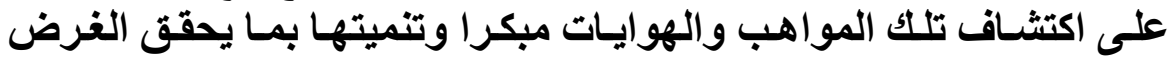
المطلوب.

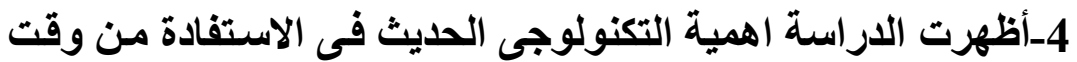

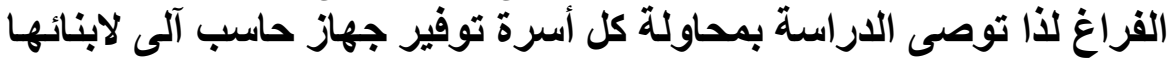

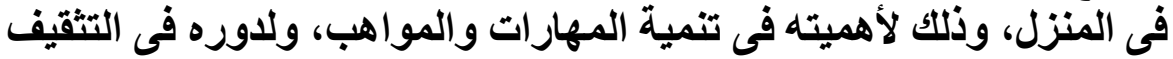

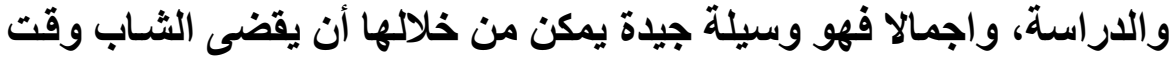

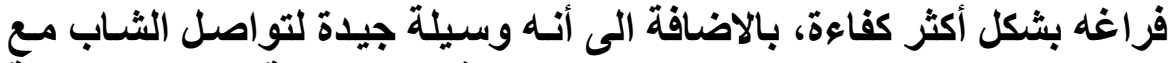

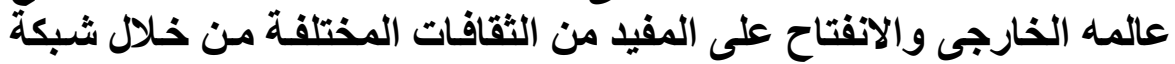

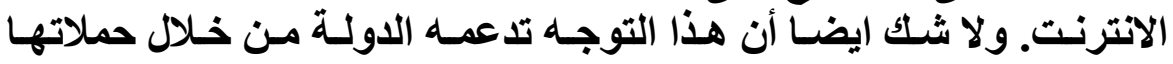

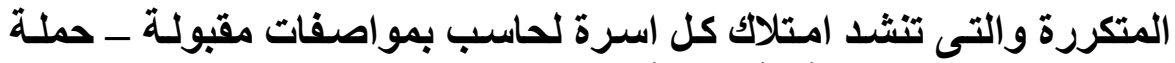
حاسب لكل بيت ـ كمـا أن أسـعار أجهزة الحاسب الأب حاليا اصبحت في متنـاول معظم الاسر.

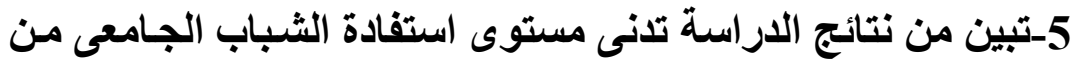

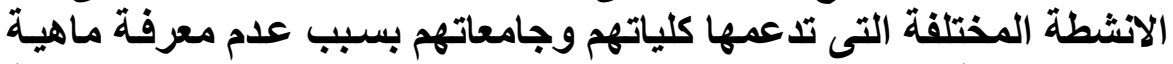

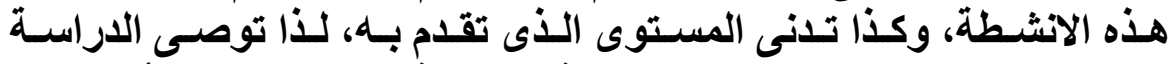

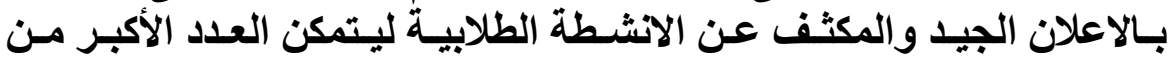

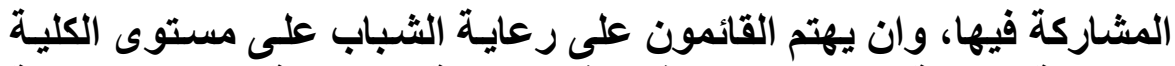

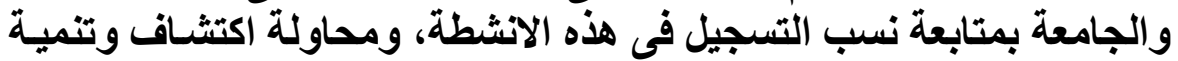

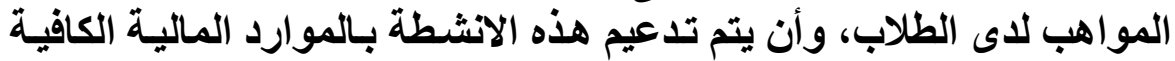

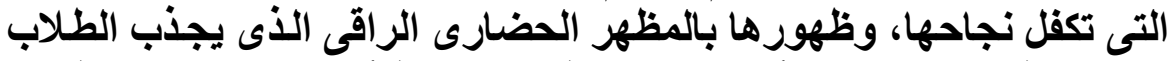

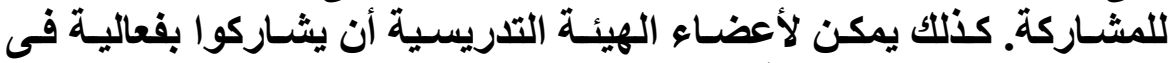

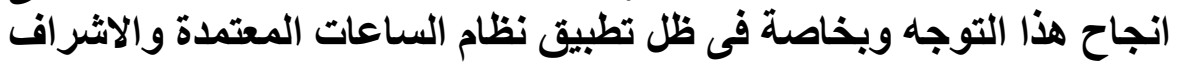
الاكاديمى. 


\section{المـر اجم}

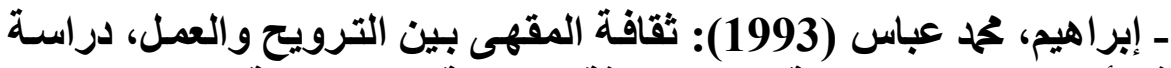
فى أسلوب الحياة اليومية، دار المعرفة الجامعية، الإسكندرية.

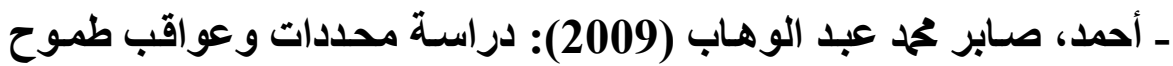

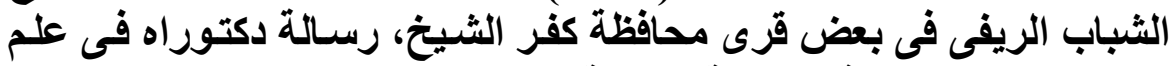

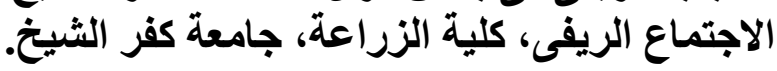

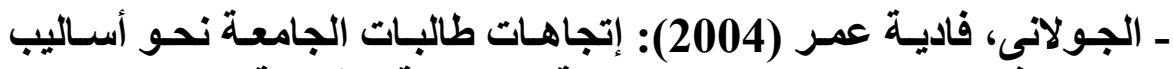

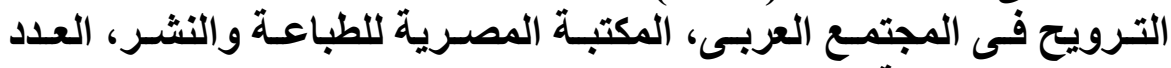
التاسع، الاسكندرية.

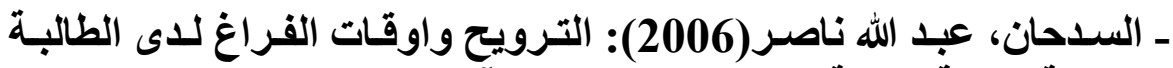
الجامعية، مجلة جامعة الملاك سعود، م19، الآداب (1)، (1).

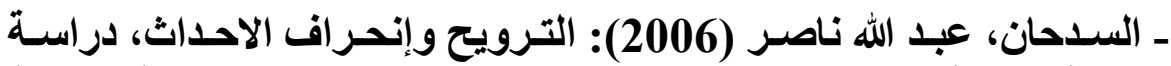

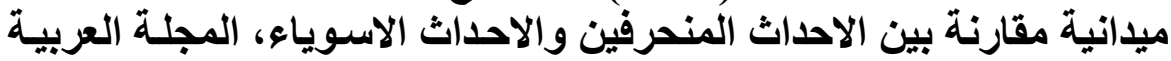

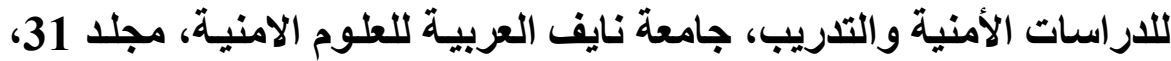

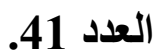

ـ السدحان، عبد الله ناصر (1994): قضساء وقت الفراغ واغ وعلاقته بـانحر اف الأحداث، المركز العربى للاراسات الأمنية والتدريب، الرياض.

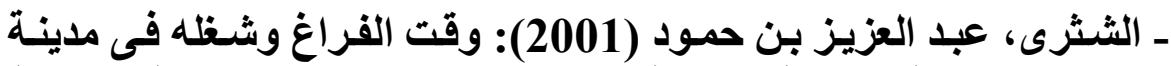

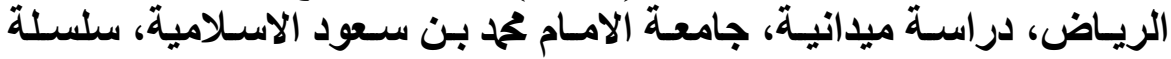

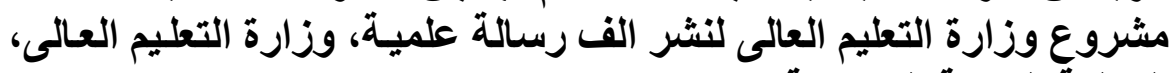
المملكةٌ العربية السعودية.

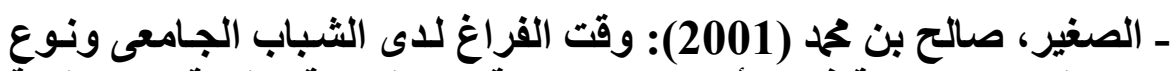

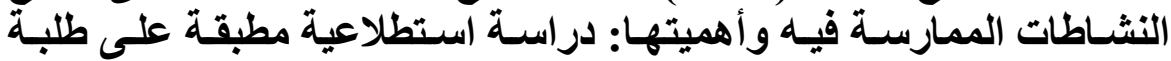
جامعة الملك سعود بالرياض، مجلة الملثك سعود، م13، الآداب (2) (2).

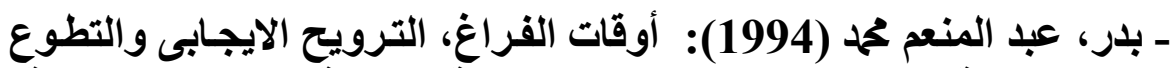

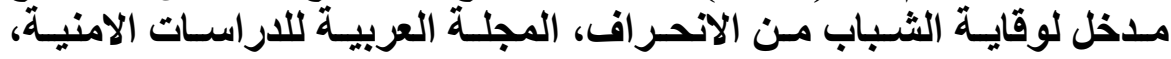

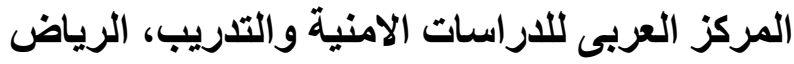

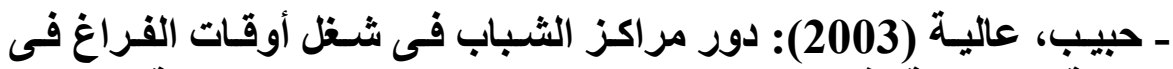
القريـة المصـرية، فى : علـم الاجتمـاع الريفـي (دراسـات نظريـة وبحـوث 
ميدانية)، تحرير: عليـاء شكري، وأحمد مجدي حجازى، مطبعة العمرانية،

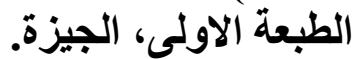

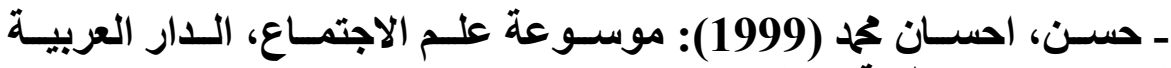
للموسوعات، الطبعة الاولى، بيروت.

ـ زايد، أحمد (2006): خطاب الحياة اليومية فى المجتمع المصرى، نهضئة مصر للطباعة والنشر والتوزيع، القاهرة.

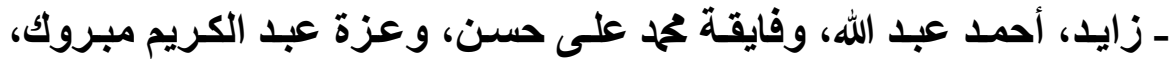

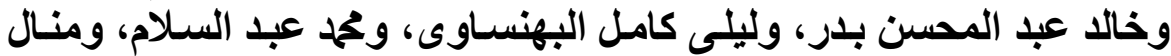

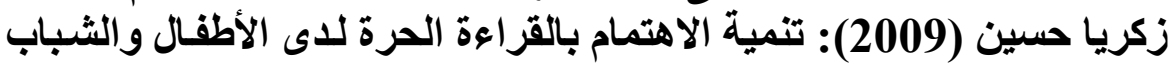

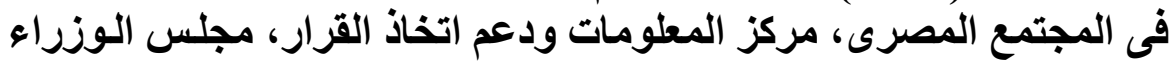
المصري، وكلية الآداب جامعة القاهرة، يونيو.

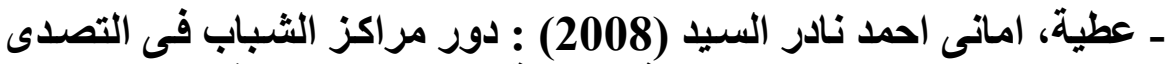

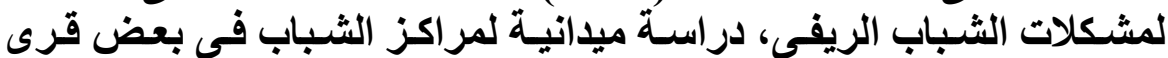

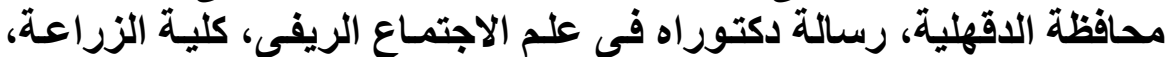

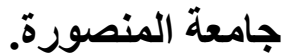

ـ عفيفى، عبد الخالق محمل (1997): الرعاية الاجتماعية "المفـاهيم، النثـأة، المجالات"، مكتبة عين شمس، القاهرة.

ـ علام، صلاح الدين محمود (1985): تحليل البيانـات فى البحوث النفسية والتربوية، دار الفكر العربى، القاهرة.

ـ غيث، محمث عاطف (1988): قاموس علم الاجتماع، دار المعرفة الجامعية،

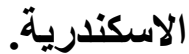

ـ فروم، إريـــ (1960): المجتمـع السليم، ترجمـة: محمود محمود، مكتبـة الأنجلو المصرية، سلسلة الفكر المعاصر.

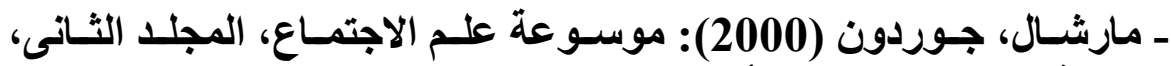

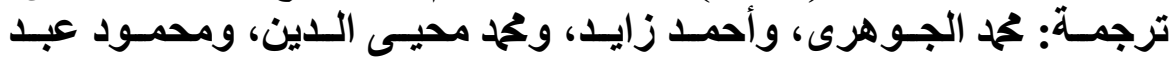

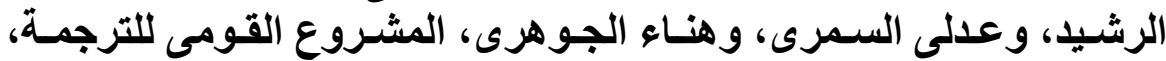
المجلس الاعلى للثقافة، الطبعة الأولى، القاهرة.

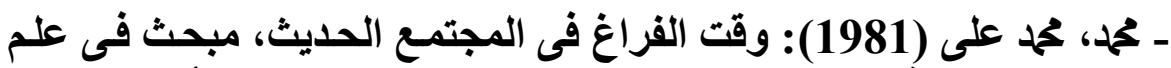

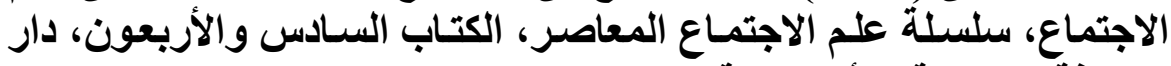
المعرفة الجامعية، الأسكندرية. 


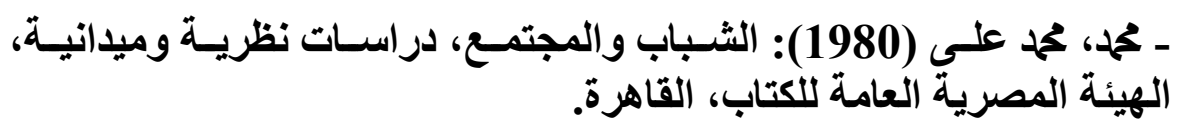

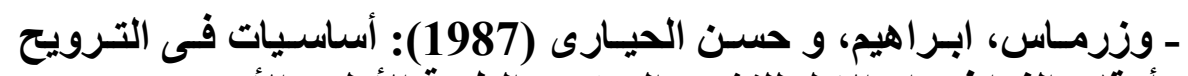

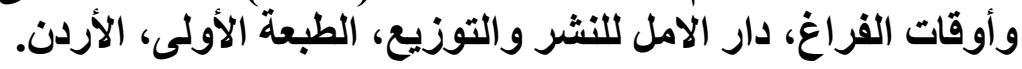

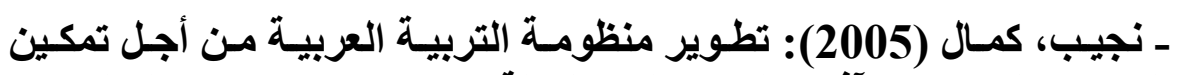

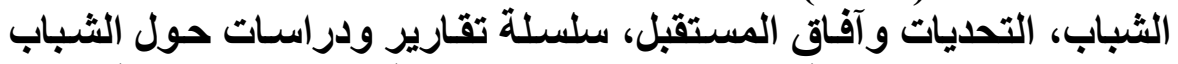

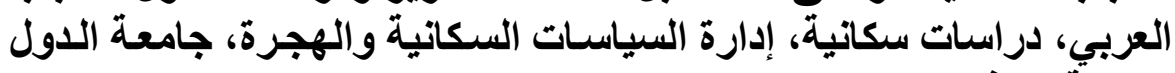

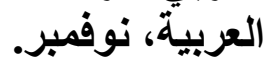

-Chris, Rojek (2006) : The concept of Leisure, In Bryan S. Turner (Ed.), The Cambridge dictionary of sociology, Cambridge university press.

- H. Etzkowitz and R. M. Glassman (1997): The Renascence of Sociological Theory (Itasca, Illinois: Peacock publishers.

-United Nations publication (1992): Statistical charts and indications on the situation of youth 1970-1990, department of economic and social development, statistical office, series Y, No.6, New York.

-WWW.Takingitglobal.org (Jennifer Courier (2004): role of youth survey) 